Historic, Archive Document

Do not assume content reflects current scientific knowledge, policies, or practices. 

$x_{1}+20=$

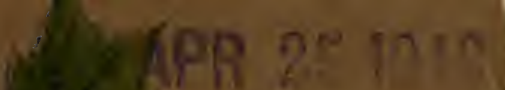

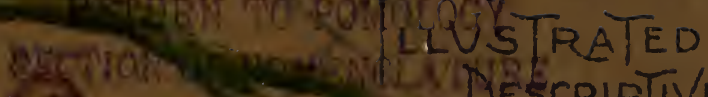

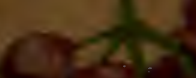

8

$7 y^{2}=$ sit.

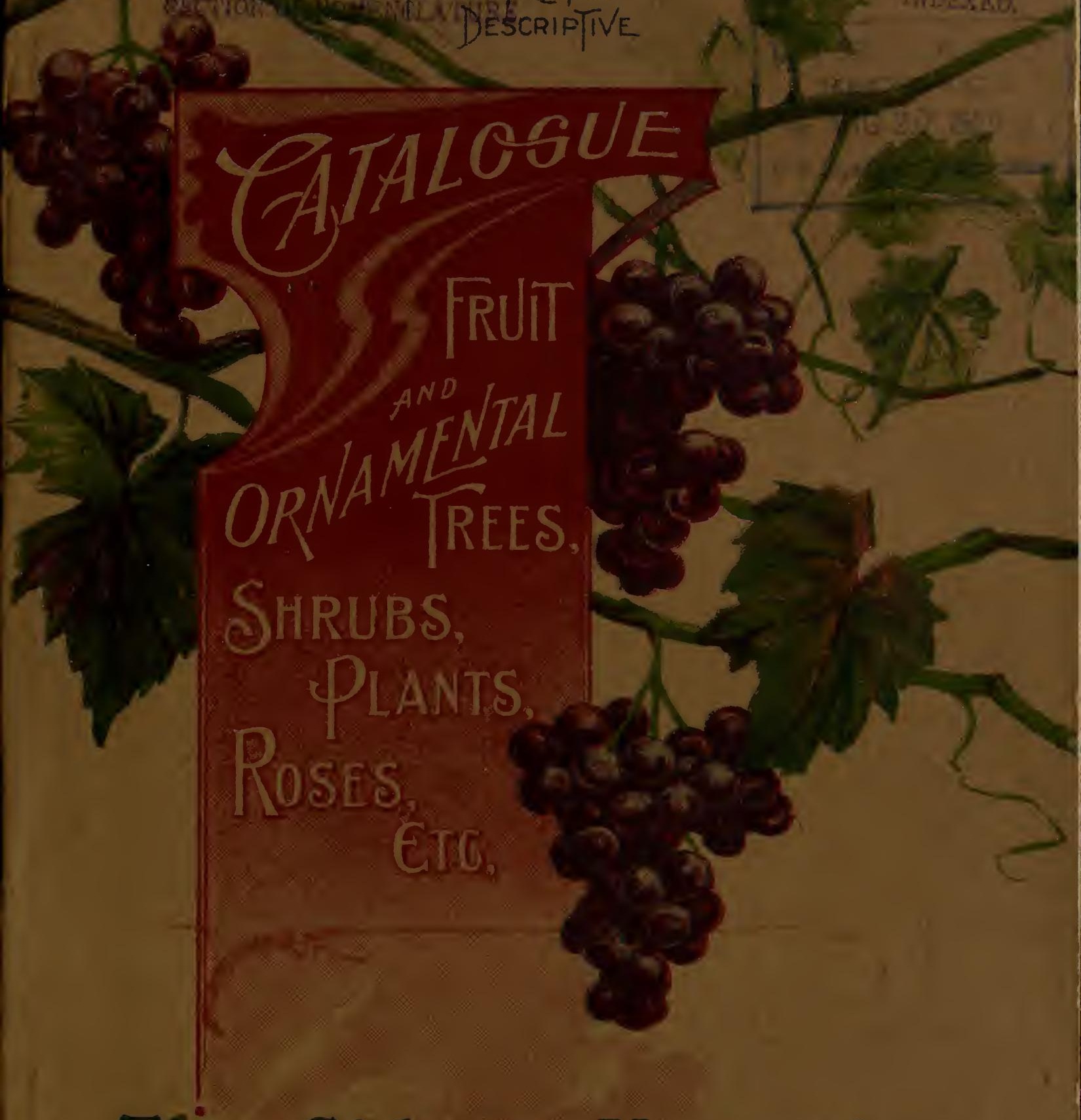

The Sidney Nurseries

GEO. HEMM, Proprietor

SIDNEI, = $\quad$ O OHIO 



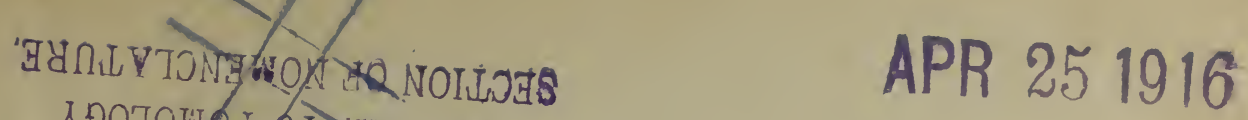

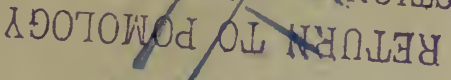

GENERAL CATALOGUE

$0 \mathrm{~F}$

\title{
FRUIT AND ORNAMENTAL TREES
}

\section{SHRUBS，ROSES，PAEONIES}

\author{
HARDY BORDER PLANTS
}

BULBS, ETC.

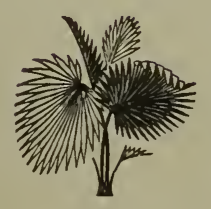

PUBLISHED BY

ROCHESTER LITHOGRAPHING COMPANY ROCHESTER, N. Y. 


\section{Notice to Customers}

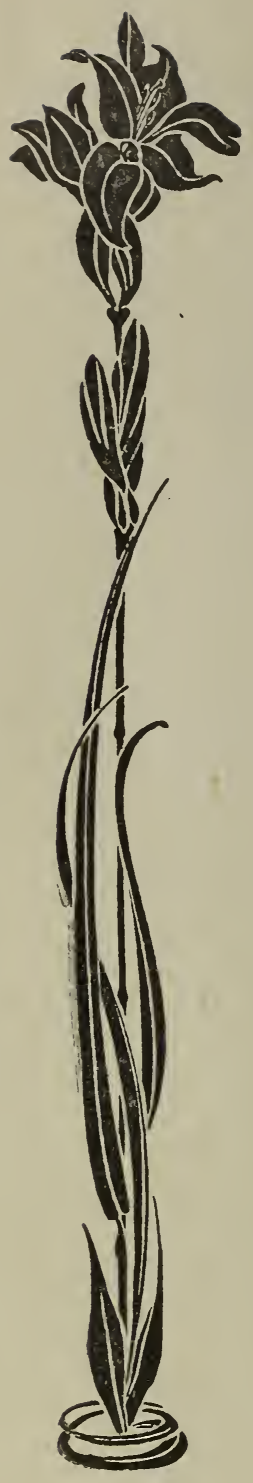

1. Orders should be sent in as early as possible, that there may be plenty of time for shipping long distances when necessary.

2. Buyers ordering by letter, should write out their orders plainly, on a separate list, and not on the body of the letter. It will prevent mistakes in the hurry of the packing season.

3. Give plain and explicit shipping directions. When none are given we forward according to our best judgment; but in no case do we assume any responsibility after the delivery of stock in good condition to the forwarder.

4. All orders from unknown correspondents must be accompanied with the cash or satisfactory references.

5. If the varieties of fruit ordered cannot be supplied, others equally as good, and ripening about the same season, will be substituted, unless ordered to the contrary.

6. We recommend that purchasers leave the selection of varieties with us, as far as possible merely stating the proportion of summer, fall and winter fruit wanted, as our experience enables us to select such sorts as are adapted to the locality. We will cheerfully give our personal attention to all such orders, and our customers can depend on getting, not only the best varieties, but those that are best adapted to the location.

7. Immediate notice should be given to us of any error in filling out an order, so that we may at once rectify the mistake, or give a satisfactory explanation. 


\section{INTRODUCTION}

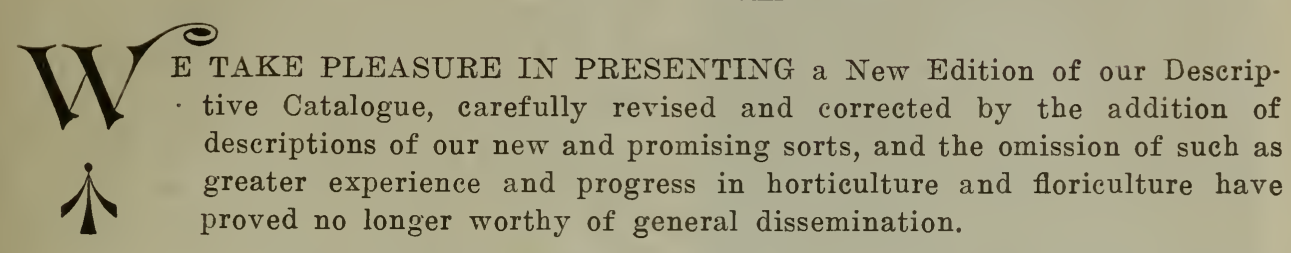

The continued patronage of our friends, as shown by their frequent and increasing orders, assures us that our efforts to please them are appreciated. This will stimulate us to still greater efforts, and will warrant us in making expenditures necessary to secure the best results.

Nothing better illustrates the progress of our country, the advance in civilization its people are making and the fact that they are learning to live better, than the greatly increased and continuing demand for nursery stock, both fruit and ornamental.

- While this demand is stipulated in part by the knowledge of the great profits which result from the systematic planting and careful cultivation of many kinds of fruit, it is by no means limited to this incentive. In every rank and station of life, including the humblest and the most opulent, those residing in town and country people are beginning to see that nothing can add so much to the comforts of living as a constant supply of the best varieties of the different fruits for home use, and nothing will do so much to adorn their homes, gratify a sense of the beautiful, and produce refinement in their families as the planting of such well-selected varieties of ornamental trees, shrubs, roses, clematis, etc., as the ground about their houses will permit.

Some persuade themselves that the demand for fruit and fruit trees has already reached its limit, but canning and the improved methods of factory drying have increased the domestic consumption of the different fruits, by rendering them nearly as good as fresh throughout the year, and that by means of these processes and improved facilities for shipping fresh fruits, the fruits of the United States can be exported to the remotest quarters of the globe. Millions upon land and sea are now supplied who have hitherto been deprived of such luxuries and no one can doubt that the setting of trees and plants for the production of large and small fruits at a much better profit than can be derived from ordinary farm crops, is also in its infancy.

We would not tempt the uninitiated with the promise of a large fortune in a few years without labor or trouble, but we do say, that the business of fruit growing, conducted with energy, perseverance and intelligence, will bring an ample and sure reward.

Good cultivation-by which we mean keeping the ground sufficiently fertile and at all times mellow and free from weeds, together with thorough drainage, either natural or artificial-is absolutely necessary to success. This with judicious pruning and proper selection of varieties suitable for the locality will, in nearly all portions of the United States, produce gratifying results.

We devote our personal attention to every branch of our business. We aim to include in our assortment the best varieties in each class, for market and family use, and persons ordering from us may rely upon our giving careful attention to their interests. 


\section{Hints on Transplanting, Etc.}

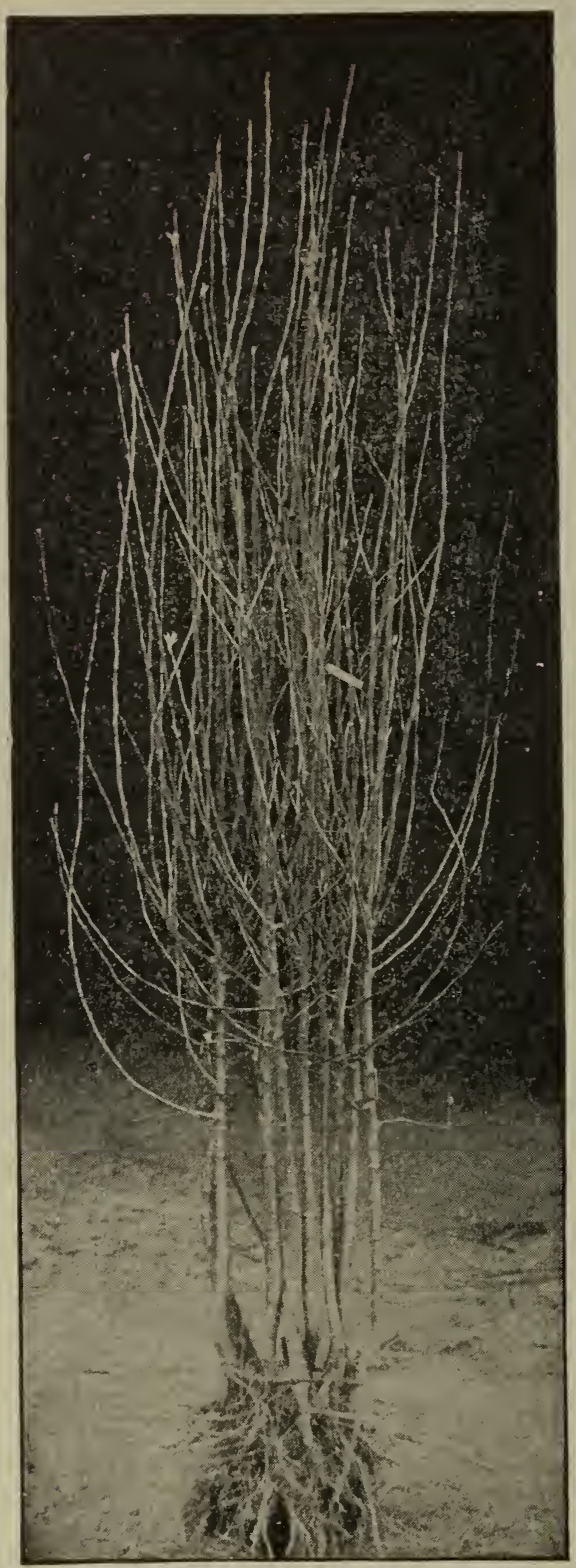

Preparation of the Soil-Prepare a rich, deep bed of mellow soil, and have the land sufficiently drained to relieve the roots from standing water. To insure a fine growth, land should be in as good condition as is required for a crop of wheat, corn or potatoes.

Preparation of Trees or Other Stock-We use great care in digging and packing, but the loss of some small roots and fibers is unavoidable. If stock is properly prepared before it is planted, no permanent injury will result from this, but the preservation of the natural balance between tops and roots renders a vigorous cutting back of the former absolutely necessary in most cases. And therefore, prune off broken ends of roots, if any (a smooth cut root granulates or makes ready to extend sooner than one broken off), cut back the tops to the extent of about one-half the previous season's growth, taking care at all times to prune in such a manner as will tend to develop a well-formed head, sufficiently open to admit air and light freely. Evergreen and other ornamental trees, the beauty of which depends on preserving their natural form, should be pruned very little. Hence, great pains should be taken in planting and caring for these. If not ready to plant when the stock arrives, "heel it in" by placing the roots in a trench and covering them with mellow earth, well packed.

Planting-Make the holes large enough to admit the roots without any cramping or bending, and deep enough to bring the tree to its natural depth. The fine surface soil should be used in covering the roots, and this should be carefully worked among them. If the ground is dry it is well to pour in some water when the hole is partially filled. See that the ground is firmly and solidly packed over all parts of the roots by exerting the full weight of the planter upon it, so that there will be no opportunity for dry air or frost to enter and destroy roots deprived of the full benefit of their natural protection. Omission to pack the earth solidly is a most frequent cause of failure in planting nursery stock. Fill the holes full enough to be even with the surrounding surface after the fresh earth settles. Always remove the label when planting. If this is left until the tree is grown, the connecting wire often cuts into and destroys the tree or branch to which it may be attached. Never use wire in contact with roots. When planting dwarf trees set them low enough to cover the stock upon which they are budded, but not lower. Large standard trees should be staked and tied so that the wind will not loosen the roots. This should be so done that the bands will not chafe the trees. It is a very good way to drive two stakes and confine the tree between straw or hay bands stretched from stake to stake.

Mulching-When trees or bushes are planted, they should be mulched or covered with a layer of coarse manure or litter from three to six inches deep for a space of say, two feet more in diameter than the extent of the roots. This keeps the earth moist and even temperature. 
After-Culture-Grass should not be allowed to grow about young trees or plants. The ground should be cultivated for a space of at least a foot outside the roots. If the ground is poor it should be enriched with surface applications of manure. Pruning should be varied according to the condition of the tree and the purpose of the planter. It should be done regularly every spring before the buds swell any. In this way the removal. of large branches will be avoided.

Fall Planting-When planted in the fall, all trees should be banked up at least one foot high until spring. This overcomes the tendency of the trees to heave out, protects them from mice and prevents the roots from freezing before they have taken hold of the soil. In planting roses, shrubs, vines, and other delicate stock in the fall, the tops should be nearly or quite buried with mellow earth during the first winter. The surplus earth should be removed in the spring.

Injured Trees-If trees are received in a frozen state, place the package unopened in a cellar, away from frost and heat, until thawed out and then unpack. If partially dried from long exposure, bury entirely in the ground or place in water from 12 to 24 hours.

\section{WINTERING NURSERY STOCK PRODUCED IN THE FALL}

In sections where the winters are very severe, it is not advisable to set out young trees and plants in the fall, but the practice of procuring them in the fall and planting them in the spring is becoming more and more popular as experience has demonstrated its advantages. In the fall nurserymen are not hurried with their own planting; the season for shipping is comparatively long, and the weather not nearly so changeable as in the spring. Railways are not so much hurried and there is much less chance for injurious delays than in the spring. It being practicable to plant trees so procured as soon as the frost is out, they become thoroughly established the first season.

There is a popular impression that trees dug in the fall and heeled in over winter are worthless. If the heeling is well done there could not be a greater mistake. Peach and some other young trees, if left standing during the first winter are frequently killed or injured by frost, while if dug in the fall and treated as below described, they come through bright and uninjured.

To insure success, select a dry spot where no water will stand during the winter, having no grass near to invite mice. Dig a trench deep enough to admit one layer of roots, and sloping enough to admit the trees to lay at an angle of not more than 30 degrees with the ground. Having placed one layer of roots in this trench; cover them with mellow earth extending well upon the bodies and see that this is firmly packed. Then add another layer of trees overlapping the first, and continuing as at first until all are heeled in. As soon as this is done, cover the tops so well with evergreen boughs that they will be thoroughly protected from the winds. Roses and other small stock may be wholly covered with earth.

\section{DISTANCES FOR PLANTING}

Standard Apples ............................ 40 feet apart each way

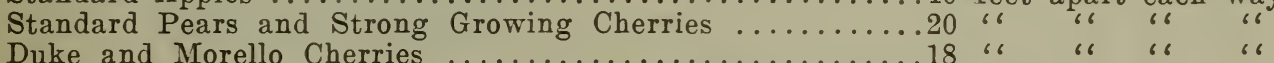

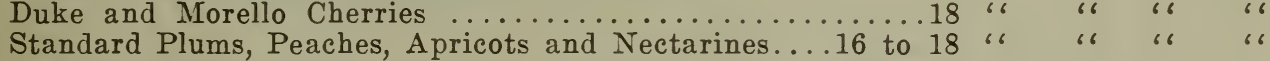

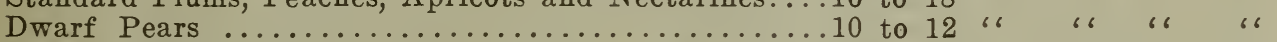
Dwarf Apples .................. " " " "

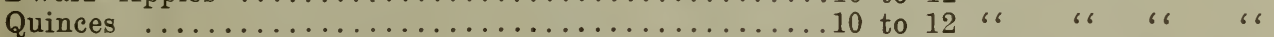
Grapes ............................ 10 to 16 feet apart; 7 to 16 feet in rows Currants and Gooseberries ...................................... feet apart Raspberries and Blackberries ...................... to 4 by 5 to $i$ feet Strawberries, for field culture $\ldots \ldots \ldots \ldots \ldots \ldots \ldots \ldots \ldots \ldots \ldots \ldots \ldots \ldots \ldots \ldots \ldots$ by 3 to $31 \frac{2}{2}$ feet Strawberries, for garden culture $\ldots \ldots \ldots \ldots \ldots \ldots \ldots \ldots \ldots \ldots \ldots \ldots \ldots \ldots \ldots \ldots$ to 2 feet apart

NUMBER OF TREES ON AN ACRE

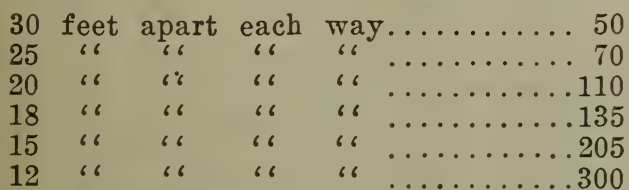

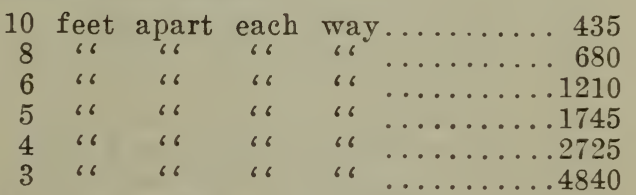

Rule-Multiply the distance in feet between the rows by the distance the plants are apart in the rows, and the product will be the number of square feet for each plant or hill, which, divided into the number of square feet in an acre $(43,560)$, will give the number of plants or trees to the acre. 


\section{FRUIT DEPARTMENT}

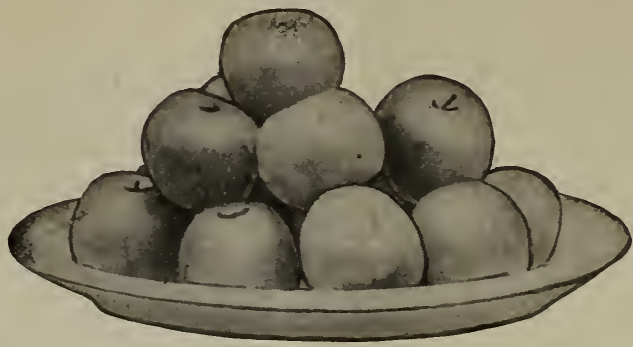

APPLES

'The first fruit of importance is the Apple. Its period of ripening, unlike that of other fruits, extends nearly or quite through the year. By making judicious selections of summer, autumn and winter sorts, a constant succession can be easily obtained of this indispensable fruit for family use.

There is no farm crop which, on the average, will produce one-fourth as much income per acre as will a good apple orchard. The average prices paid for the fruit is steadily on the increase, and the immense demand for home consumption, foreign shipping, canning and evaporating, assures us that they will continue to increase.

If apples are planted at the rate of fifty trees per acre, rows of peach trees can be planted between the apples which, growing more quickly than the apple trees, soon protect them from the winds, and thus prove a great benefit to them. After eight or ten years of productiveness, as the space is needed for the apples, the peach trees may be removed, leaving the orchard better for the protection, and at the same time having yielded the planter a large return for his outlay and labor.

\section{SUMIMER}

Benoni-An excellent early apple. Tree vigorous and upright, hardy and productive. A valuable variety for home or market, Flesh yellow, tender, pleasant, sub-acid; core small. August.

Caroline Red June-(Red June)-Medium size, red; flesh white, tender, juicy, sub-acid; an abundant bearer. June.

Duchess of Oldenburg-Of Russian origin. Large size, roundish, streaked with red and yellow; flesh whitish, juicy; flavor sprightly sub-acid; tree a vigorous grower, very hardy; very early and abundant bearer. While it is indispensable in the North, it is almost equally so in the South. September.

Early Harvest-Medium to large; pale yellow; fine flavor. Tree a moderate, erect grower, and a good bearer; a beautiful and excellent variety for both orchard and garden. Middle to end of August.

Early Strawberry-Medium, striped with deep red; tender, sub-acid and excellent; a poor grower but productive. August.

Golden Sweet-Rather large; pale yellow; very sweet and good. Strong grower and good benrer. August.
Kèswick Codlin-Large, conical; tender, juicy, acid; excellent for cooking. Tree erect, vigorous, productive and early in bearing. July to October.

Primate-Above medium; straw color, tinged with blush; tender, fine-grained, juicy and sub-acid; a vigorous grower and abundant bearer. Ripens August and September.

Red Astrachan,-Large roundish; nearly covered with deep crimson, overspread with a thick bloom; juicy, rich, acid, beautiful. The tree is a vigorous grower, with large foliage and a good bearer. August.

Summer Queen-Medium to large, roundish; surface yellow, blotched and streaked with red, flesh yellow and tender, with an acid, aromatic flavor. July and August.

Sops of Wine-Medium size, oblong, red; flesh white, often stained; mild and pleasant; productive. August and September.

Sweet Bough-Large, pale greenish-yellow; tender and sweet. Moderate grower and good bearer. August. 
Tetofsky-A Russian apple which has proved profitable for market growing. Hardy as a Crab. Fruit good size nearly round; yellow, beautifully striped with red; flesh white, juicy, pleasant, acid, aromatic. July and August.
Yellow Transparent-A Russian variety. Tree an upright grower and a very early and abundant bearer. Fruit of good size; skin clear white, turning to a pale yellow; flavor acid and very good. Ripens from ten days to two weeks earlier than Early Harvest.

\section{AUTUMN}

Alexander-(Emperor)-Of Russian origin. Large, deep red or crimson; flesh yellowish-white, crisp, tender, with pleasant flavor. Very hardy. October.

Autumn Strawberry-Medium, streaked; tender, juicy, sub-acid, fine; vigorous and productive. September and Octo-ber.

Fall Jennetting-Large, oblate; pale greenish-white with a blush; tender, juicy, mild and sub-acid. Tree vigorous, spreading and productive. November.

Fall Pippin-Very large; yellow, tender, juicy and rich. Tree vigorous. October to December.

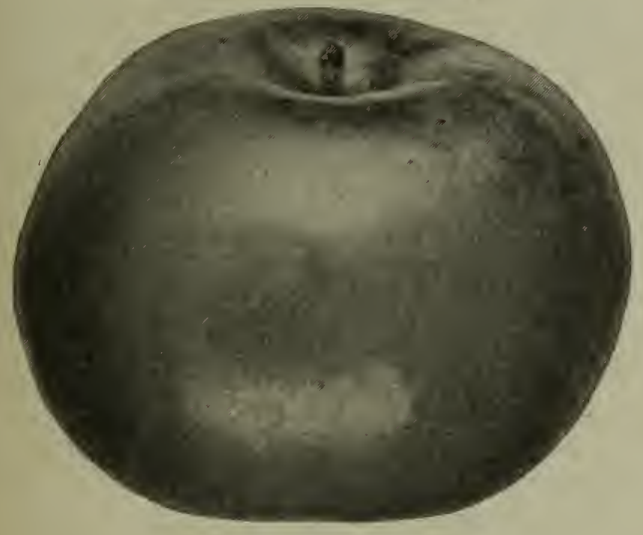

FAMEUSE

Fameuse-(Snow Apple)-Medium size, roundish, oblate; whitish ground, striped with deep red; flesh very white juicy and pleasant. Tree very hardy; one of the most valuable Northern sorts. November and December.

Gravenstein-Large, stripcd and beautiful; tender, juicy and high flavor; vig. orous and productive. September and October.

Haas-(Gros Pomier. Fall Queen)-Medium to large, slightly conical and somewhat ribbed; pale greenish-yellow, shaded and striped with red; flesh fine, white, sometimes stained; tender, juicy, sub-acid, good. Tree vigorous and very hardy; upright grower with well-formed head; bears early and abundantly. September to November.
Jersey Sweet-Medium; striped red and green; very sweet, rich and pleasant. Good grower and bearer. September and October.

Lowell-(Orange, Tallow or Greasy Pippin)-Large, oblong; skin oily, pale yellow; brisk, juicy, rather acid flavor. Good for table and cooking. Septem. ber and October.

Maiden's Blush-Medium size, flat, quite smooth and fair; pale yellow, with beautiful red cheek; tender, sprightly, pleasant, acid flavor. Fair grower and good bearer. September and October.

Porter-Rather large; yellow, tender, rich and fine. Moderate grower, but productive. September and October.

Pumpkin Sweet-(Pumpkin Russett)-A very large, round, yellowish russett apple, very sweet and rich. Tree a vigorous, rapid, upright grower; valuable. October and November.

Rambo-Medium; yellowish, streaked with dull red and somewhat dotted; mild, tender and good. Fine grower, productive; more especially valuable in the West. October to December.

Red Beitigheimer-A rare German variety. Fruit large to very large; skin pale green color, mostly covered with purplish-crimson; flesh white, firm, subacid, with a brisk, pleasant flavor. Tree a fine grower, abundant bearer. September and October.

Sherwood's Favorite, or Chenango Strawberry-Medium size; oblong and indistinctly ribbed; of a light color, splashed with dark crimson; flesh white, juicy, very mild and tender, slightly sub-acid. Very much esteemed for the table, and popular wherever grown. September and October.

Smoke House-Large, yellow, shaded with bright red; flesh firm, crisp, juicy and fine flavored. Especially esteemed in Pennsylvania. Oct. and Nov.

Stump-A well tried apple. Of good size, roundish, conical, flesh firm, crisp, juicy, tender, sprightly sub-acid; greenish-yellow, stained with red; beautifully fair, and has commanded the highest prices wherever shown. October to December. 
Twenty Ounce-Very Large, nearly round; yellow, striped with red; quality good; vigorous and good bearer; popular as a market variety. November and December.
Walter Pease-Fruit very showy and attractive, and as a dessert or fancy market' apple has no superior. Core very small, flesh white, fine grained; quality best; mild, juicy, slightly subacid, with a rich sweet, aromatic flavor. Tree vigorous and very productive. New. September.

\section{WINTER}

America-Originated not far from the Potomac, and brought to notice at the close of the Civil War. One of the best and most popular apples brought to the Washington markets. Tree a vigorous grower and an annual bearer of uniform and perfect fruit. Season, February and March.

Arkansas Beauty-Large to very large; deep red, tender, yet firm; one of the handsomest apples grown; quality good. Tree hardy, vigorous and very productive. December to May.

Arkansas Black-Fruit large, round, oblong covered all over with a very dark red. Much darker than Wine Sap; flesh orange yellow. A splendid keeper.

Bailey Sweet-Large; deep red, tencler, rich, sweet; vigorous, upright, good bearer. November to April.

Bismarck-Introduced from New Zealand. Very large, remarkably handsome and showy; flesh yellow, tender, juicy; quality good; extremely hardy and prolific; bears early. Season November to February. New.

Baldwin-Large, roundish, deep bright red; crisp; sub-acid, good flavor. Tree vigorous, upright and very productive of fair handsome fruit; one of the best and most popular winter apples. January to April.

Baxter-Originated in Canada, on the banks of the St. Lawrence. Above medium size; dark red, spotted, mild, sub-acid, quality good.

Belle de Boskoop-Pronounced one of the most beautiful and profitable of the Rusian varieties. Large, bright yellow, light red on sunny side, flesh crisp, firm, juicy, sprightly sub-acid; quality very good. A late keeper.

Bellefleur, Yellow-Large, yellow, with blush cheek; very tender, juicy, subacid. In use all winter. Very valuable. A moderate grower and good bearer.

Ben Davis-(New York Pippin, Kentucky Streak, etc.)-A large, handsome, striped apple of good quality. Tree very hardy, vigorous and productive. A late keeper. Highly esteemed in the West and Southwest.
Bethel-Large, deep red; flesh crisp and tender. A native of Vermont, where it is highly prized for its quality and the extreme hardiness of the tree; a moderate grower. December to February.

Boiken-A new variety from Transylvania, Europe. Very hardy and a young and continuous bearer. Flesh snow white, fine grained. An excellent dessert fruit from January to June.

Bottle Greening-Resembles Rhode Island Greening, but tree a better grower and much hardier. A native of Vermont. December to March.

Cooper's Market-Medium, conical, yellow striped with crimson; flesh white, tender, brisk sub-acid. Vigorous, upright grower. December to May.

Cranberry Pippin-A first rate apple. Tree healthy and a good annual bearer. Fruit large; flesh juicy, sub-acid, and of good flavor.

Delaware Red-Medium to large; bright red, highly colored; flesh fine grained, crisp, juicy, sub-acid, excellent; remarkable for its long-keeping qualities. An early and abundant bearer. November to February.

Dominie-A large, flattened, greenishyellow apple, with red stripes; flesh white, tender, juicy. Good grower, very productive; finest in the West. November to April.

Fallawater-(Fornwalder, Tulpehocken) -Very large, globular, yellowishgreen, dull-red cheek; juicy, crisp, pleasant, sub-acid flavor. Tree a strong grower, very productive even while young. November to March.

Franklin Sweet-Originated in Franklin Co., Me., and is considered very desirable. Perfectly hardy and good quality; fair size; flesh white and very juicy; color similar to Bellefleur. Has been kept until March. A very valuable winter sweet apple.

Gano-Originated in Missouri. Form conical, good size and smooth; deep red, shaded on sunny side to mahogany; very attractive; flesh pale yellow, fine grained, tender, pleasant, mild, sub-acid; is a good shipper and keeper. Tree healthy, vigorous and hardy. An annual and prolific bearer. February to May. 
Gideon-Raised in Minnesota, from Crab seed, by Mr. Gideon. An upright grower; medium to large; color yellow, with vermillion blush on sunny side; mild acid; quality very good. December to March.

Grimes' Golden-(Grimes' Golden Pippin)-An apple of the highest quality; medium to large size, yellow. Tree hardy, vigorous, productive. January to April.

Hubbardston Nonsuch-Large; Striped yellow and red; tender, juicy and fine; strong grower and good bearer. November to May.

Huntsman's Favorite-A reliable variety for South and West. Tree a good grower and hardy; bears young and regularly. A good sort for general use.

Hurlburt-Medium size, conical; yellow, shaded with red striped and splashed with darker red; flesh white, crisp and tender; juicy, mild, sub-acid, quality excellent; begins to bear while young and continues with regularity and constant crops; very hardy and suited to the extreme North. In season during midsummer.

Iowa Blush-A large, handsome apple. Good keeper. Tree vigorous and hardy. Flesh rich, sub-acid, excellent flavor. November to February.

Jonathan-Fruit medium roundish; skin yellow nearly covered with dark or lively red; fine grained, very tender and finely flavored. Tree slender and spreading, with light-colored shoots. November to April.

King-(Tompkins County)-Large and handsome; striped red and yellow. Tree vigorous and productive. One of the best. November to May.

Lady Apple-A beautiful little dessert fruit; flat, pale yellow with a deep red cheek; juicy, rich and pleasant. November to May.

Longfield-A Russian variety imported some years since. Tree a free, upright grower, early and abundant bearer; medium to large; yellow, with a blush on the sunny side like the Maiden's Blush; rich, sprightly sub-acid; quality as good as the Fameuse and somewhat like it. December to March.

Magog Red Streak-Origin Vermont. Bears annually large crops; valuable for its extreme hardiness, vigor, productiveness and Jong-keeping; fruit medium, roundish, skin yellow, shaded with light red; flesh yellowish, a little coarse; moderately juicy, mild subacid. December to March.

Mammoth Black Twig-One of the most profitable of all apples. Resembles the Wine Sap, but is a better grower. An excellent keeper.
Mann-Fruit medium to large, roundish oblate, nearly regular; skin deep yellow when fully ripe; flesh yellowish, half fine, half tender, juicy, mild, pleasant, sub-acid. The tree grows straight and symmetrical and makes a large tree in the orchard. It is an early and annual bearer.

McIntosh Red-An exceedingly valuable, hardy, Canada sort; medium size, nearly covered with dark red; flesh white, fine, very tender, juicy and refreshing. A good annual bearer of fair, handsome fruit. Resembles the Fameuse, but larger and more hardy, and fully equal in quality to this standard sort. November to February.

Milding-Fruit large; skin smooth, whitish-yellow, splashed with rich red; flesh tender, juicy, sub-acid; tree a strong, fine grower and very productive. December to February.

Mo. Pippin-Large; rich red, with darker red stripes; very handsome and of fair quality.

Monmouth Pippin-(Red Cheek Pippin) -Large greenish-yellow, with a fine red cheek; juicy, tender and good. Tree erect, good and productive. Keeps well till March or April.

Newtown Pippin-One of the very best apples as to quality. Tree a light grower while young. Very juicy, crisp and highly delicious flavor; fine keeper. Does not succeed in all sections. December to May.

Nodhead-(Jewett's Fine Red)-Medium size; greenish, white striped and splashed with crimson having a dull, grayish bloom; flesh tender, juicy, almost sweet. Popular in Northern New England on account of its great hardiness. A good grower and bearer.

Northwestern Greening-This apple is the best keeper we have-keeping in good condition generally till May. The apple is very large and of beautiful form, and being of fair quality is bound to become very popular. The tree, when young is a fine upright grower; spreading top when bearing.

Northern Spy-Large; roundish, slightly conical, somewhat ribbed, striped, with the sunny side nearly covered with purplish red, sub-acid, rich and delicious flavor; in perfection in January and keeps till June. The tree is a strong, upright grower, and forms a very compact head. Should be kept opeu by pruning so as to admit the air and light freely.

North Star-Large; very handsome; perfectly hardy; vigorous, quality fine; a seedling of Duchess, which it resembles, but less tart and better quality. 
Okabena-Originated near Lake Okabena, Minn. It is a hardy, vigorous grower; early and productive bearer. Fruit medium size, striped with red similar to Duchess; quality good with mild sub-acid flavor; season medium. Good dessert and cooking apple. This is an excellent variety to follow Duchess.

Opalescent-New. All who have examined the Opalescent regard it as the handsomest apple grown. It is not only highly colored but susceptible of a very high polish, reflecting objects near it like a mirror. This feature makes it a highly prized sort for fruit stands. The flesh is yellowish, tender, juicy and good, size large to very large and color light shading to very dark crimson. Season December to March.

Ontario-A cross between TVagener and Northern Spy. Fruit large to very large; flavor a brisk sub-acid, sprightly, slightly aromatic; season mid winter to late winter. One of the best apples both for commercial purposes and for home use.
Patten's .Greening-Seedling of the Oldenburg and equals it as an orchard tree in hardiness and bearing. Large; equally good for eating and cooking. Season Cctober to January or later.

Peck's Pleasant-Large; pale yellow, very tender and rich, with a Newtown flavor. Tree erect and fine bearer. November to March.

Peerless-Tree a very fine, straight, upright grower. Originated from seed of Duchess planted by J. G. Miller, near Faribault, Minn. It is quite hardy and productive; fruit medium size, of a pleasant, sub-acid flavor; color red on a yellowish-green ground. Stem short and hangs on the tree well; perfectly hardy here.

Pewaukee-A seedling from Duchess. Fruit medium to large, striped and splashed; flesh yellowish-white; flavor sub-acid, rich, aromatic, spicy; quality good. Tree strong grower and very hardy. January to June.

Plumb's Cider-A native of TVisconsin, where its hardiness has been abundantly proved. Tree vigorous, roundheaded and productive. Flesh whitish, fine, tender, juicy, mild, sub-acid. September to January.

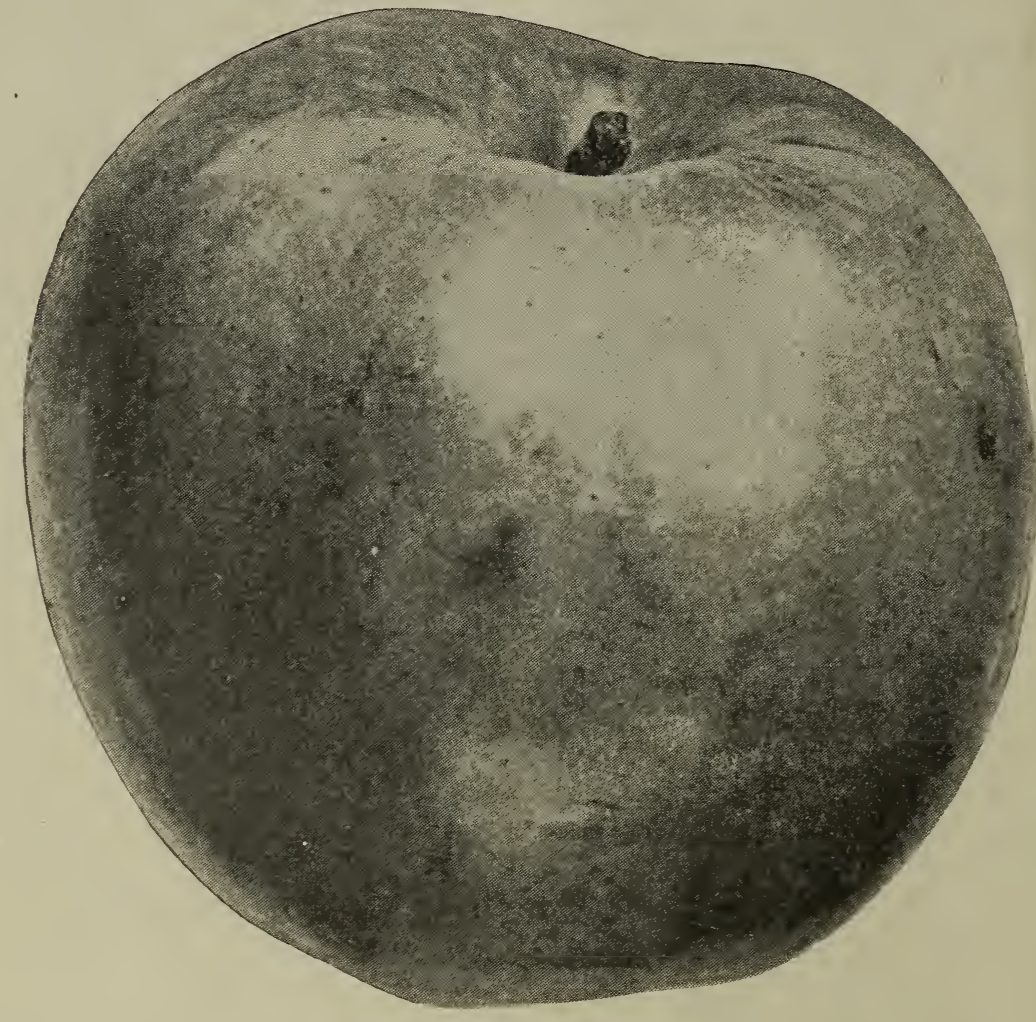

PARAGON

Paragon-Large to very large; deep red; tender yet firm;one of the handsomest apples grown; quality extra good. Tree hardy, vigorous, very productive. Season December to May.
Rawle's Janet-(Never Fail)-Medium, roundish, ovate, greenish-yellow and streaked with red; crisp, rich and juicy. One of the best and longest keepers in the South and Southwest. 
Red Canada-(Old Nonsuch of Mass., Steele's Red Winter)-Medium, oblate, red, tender, crisp, rich, sub-acid, refreshing and delicious. Tree thrifty, but a tender grower. Productive. January to May.

Red Russett-Said to be a cross between the Baldwin and Rox Russet. Good grower, regular bearer, and resembles the Baldwin. Flesh crisp, juicy, pleasant sub-acid. Keeps till April and May. Good eating in February. Fruit always large, uniform and handsome.

Rhode Island Greening-Large; greenishyellow; tender, juicy and rich, with rather an acid flavor, growing strong and spreading and an abundant bearer. December to April.

Rolfe-Originated in Maine, about the 45th degree. Fruit large, of magnificent appearance; color dark red; an abundant and annual bearer, and where known the fruit outsells all others of its season. Quality prime, both for eating and cooking. One of the very best. November to January.

Rome Beauty-Large, yellow, shaded with bright red; flesh yellowish, tender, juicy, sub-acid; moderate grower. November to February.

Rubicon-A comparatively new apple most beautiful and showy; a poor grower and regular bearer; medium size; yellow, shaded with bright red; juicy and firm, with brisk, sub-acid flavor. December to June.

Russet, Golden-Medium size, dull russet with a tinge of red on exposed side; flesh generally crisp, juicy and high flavored. Tree vigorous grower and a great bearer; very popular. November to April.

Russet, Roxbury or Boston-Medium to large; greenish or yellow russet; crisp, good, sub-acid flavor. Tree vigorous and productive; very popular on account of its long keeping. June.

Salome-New, hardy, productive; keeps the year around; ripens into fine condition in winter and remains fresh, plump and juicy till summer. Has stood the test and proved itself without a rival. January to May.

Seek-no-Further-(Westfield) - Medium to large, slightly russeted with dull red stripes; tender, rich, spicy and fine; good grower and bearer. November to February.

Smith's Cider-Medium, striped; flesh tender, juicy, sub-acid; very popular in Pennsylvania and Western States. December to March.

Spitzenburg, Esopus-Medium to large, deep red; flesh yellow, crisp, sub-acid, high flavored. Tree a light-grower in the nursery, but bears and grows well transplanted in rich soil. November to April.
Stark-Esteemed as a long keeper and valuable market fruit. Fruit large, roundish; skin greenish yellow, much shaded with light and dark red, and sparkled with brown spots; flesh yellowish, juicy, mild sub-acid. January to May.

Stayman's Wine Sap-Similar to Wine Sap except larger, better quality and more productive. December to May.

Sutton Beauty-Fruit large, waxy yellow striped with crimson; flesh white, tender, juicy, mild acid; quality good and a remarkable keeper. Tree vigorous, a handsome grower, very productive. One of the most valuable market sorts in Western New York.

Talman's Sweeting-Medium, , pale yellow, slightly tinged with red; firm, rich and very sweet; the most valuable baking apple; vigorous and productive. November to April.

Wagener-Medium to large; deep red in the sun; flesh firm, sub-acid and excellent; very productive, bears very young. December to May.

Walbridge-Medium size, striped with red; handsome and of excellent quality; vigorous grower and productive; very hardy and considered of great value in the North and Northwest. March to June.

Wealthy-A native of Minnesota, where it has proved perfectly hardy, vigorous and productive; fruit of medium size, uniform, pleasant, acid, good red, streaked with white; quality good. December to February.

White Winter Pearmain-Rather large, conical, angular or ribbed; light yellowish-green, with a brownish-red cheek; stem short; flesh whitish, fine grained, with a mild sub-acid, rich, fine flavor. Is one of the best and most productive winter apples in the West.

Willow Twig-Tree hardy and productive; fruit tender with a pleasant subacid flavor. Valuable for late keeping.

Wine Sap-Nedium, dark red, sub-acid, excellent. Tree a moderate grower and abundant bearer. A favorite market variety in the West. December to Nay.

Winter Banana-Fine, vigorous grower, large, healthy foliage; early bearer. Fruit medium to large, smooth and handsome, golden-yellow usually shaded with red blush; flesh fine grained, rich, sub-acid, aromatic; highest quality. One of the best dessert apples. A valuable market variety in some sections.

Wismer's Dessert-Size medium to large. Smooth, beautifully colored with yellow, shaded with bright red, in stripes and blotches, marked with russet dots. Exquisite delicious flavor, juicy, melting, buttery, pear-like texture. Tree a strong grower and extremely hardy. 
Wolf River-Tree very hardy and productive; fruit large and handsome, red color, flesh white and of exceedingiy fine quality; sub-acid.

Yellow Bellfiower-Tree a strong grower and abundant bearer; fruit medium to large; flesh white, fine grained, tender, juicy, sub-acid. November to February. ,

\section{EXTRA HARDY, OR IRON-CLAD APPLES}

The opinion has prevailed that the attempt to produce valuable apples in the Northern sections of New York, New England and the adjoining portions of Canada, Wisconsin, Minnesota and other sections unfavorable for general fruit growing, must prove a failure. While this is true as to many varieties successfully grown in more temperate or favorable regions, its general application is quite erroneous. Experience in growing Russian or other varieties of Northern origin, has shown that a limited variety of fine apples can be grown as far North as Montreal, and that some of these varieties may be planted with equal profit in all sections, North and South.

Select varieties best adapted to your location and in case you are not familiar with the varieties, we will be pleased to assist you at any time.

\section{CRAB APPLES}

Within the past few year much attention has been given to improving this class of fruit, because of their adaptability to cold sections, where only a few varieties of apples can be successfully grown. These efforts have been attended with marked success. Crab apples succeed equally well in all sections, and are valuable for cider, preserving, jelly, ornament and some of the improved sorts are excellent for eating. Sent to the Eastern markets they command a very high price.

Excelsior-Raised from seed of Wealthy, in Minnesota. Very hardy, productive and one of the best flavored varieties. September.

Florence-Originated in Minnesota. The hardiest of all. An early and profuse bearer; when in full fruit the most ornamental tree grown; larger and far superior to Transcendant. Ripens about the same time.

General Grant-Tree an erect, vigorous grower; fruit in dense clusters; quality equal to Duchess of Oldenburg. October to December.

Hewe's Virginia-Rather small; round, acid; esteemed for cider.

Hyslop-Almost as large as Early Strawberry Apple; deep crimson; very popular on account of its large size, beauty and hardiness. Keeps well into the Winter.

Lady Elgin-Fruit beautiful, resembling the Lady Apple. Flesh yellowish, moderately juicy, mild sub-acid. Tree a vigorous grower and very productive. November and December.

Large Red Siberian-About an inch in diameter, grown in clusters; yellow, lively scarlet cheek. Tree erect, vigorous, bears young and abundantly. September and October.

Large Yellow Siberian-Nearly as large as above; fine amber or golden-yellow color.

Martha-Raised from the seed of Duchess of Oldenburg. Handsome, showy fruit; bears enormously; said to be equal if not superior to all others for sauce.

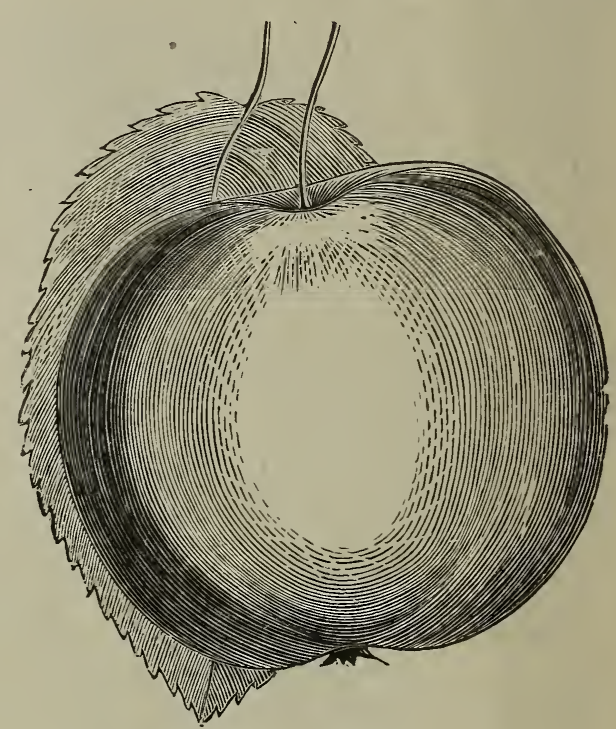

MARTHA

Montreal Beauty-Fruit large, bright yellow, nearly covered and shaded with rich red; one of the most beautiful of all Crabs in appearance. Flesh yellowish, rich, firm and acid. Very good. October'and November.

Quaker Beauty-A hardy, strong-growing sort; bears large crops of fine fruit. December to May. 
Transcendant-Medium to large; roundish, oblong; golden yellow, with a rich crimson cheek, covered with a delicate white bloom; flesh yellow, crisp and when fully ripe, pleasant and agreeable; perfectly hardy; young and abundant bearer. September and October.

Van Wyck-Large; skin mottled with bright red; sweet. Tree vigorous.
Virginia-Unsurpassed by any other. Tree hardy. Fruit highly flavored.

Whitney's Seedling-Large, averaging one and one-half to two inches in diameter; skin smooth, glossy, green striped, splashed with carmine; flesh firm, juicy and rich. A great bearer and very hardy. Tree a vigorous handsome grower. Has no superior.

\section{PEARS}

The cultivation of this noble fruit is rapidly extending as its value is appreciated. The range of varieties is such that, like apples, they can be had in good eating condition from August until early spring.

The melting, juicy texture, the refined flavor and the delicate aroma of the Pear, give it rank above all other fruits except the grape. The Pear, like most things highly desirable, and valuable, cannot be had without attention and labor. The relative prices of the Apple and Pear being about as one to five, purchasers of the latter can well afford to give the trees the high cultivation necessary to secure the best results.

Dwarf Pears must always be planted sufficiently deep to cover the junction of the Pear and Quince two or three inches-the soil made rich and well tilled and about one-half the previous summer's growth eut off each spring. Under this treatment Dwarfs are everywhere successful. The side branches should not be removed higher than one foot from the ground in Dwarfs, while the Standards may be trimmed to the height desired. Train in pyramidal form. Ripen the fruit in the house. Gather when, on gently lifting the fruit, the stems will readily separate from the limb. Place in a dark room until fully matured. Winter Pears may hang on the trees until there is danger from frost, then place in a dry cellar for maturing.

The letters " $\mathrm{D}$ or $\mathrm{S}$ "' appended to the description of varieties, indicates favorable growth, either as "Dwarfs" or "Standards" and when placed together, that they succeed as either. Those designed as "slow growers"' are usually small trees.

\section{SUMMER}

Bartlett-Large size, often with a beautiful blush next the sun; buttery, very juicy and high flavored. Tree a strong grower, bearing early and abundantly. Very popular. Last of August and first of September. S.

Beurre Giffard-An excellent variety; medium; greenish-yellow, red in the sun; very early. Tree slender but healthy; very productive. August. D. and $\mathrm{S}$.

Brandywine-Above the medium; yellowish-green, melting, sweet. Vigorous and productive. Last of August. D. and $\mathrm{S}$.

Clapp's Favorite-A large, fine pear, resembling the Bartlett, but without its musky flavor; pale lemon-yellow, with brown dots; fine texture, melting, buttery, juicy, with a rich, sweet, delicate vinous flavor. Tree hardy and very productive. Very desirable in all sections and especially so where other varieties fail. August and September. D. and $\mathrm{S}$.

Doyenne d'Ete-Small; melting, sweet, yellowish. Tree vigorous and productive. D. \& S.
Garber-Very rapid, healthy grower; makes a large handsome tree quickly. Blooms late and usually escapes Spring frost. Fruit large, of fine appearance and good quality. Ripe August and September.

Koonce-The handsomest, best and most valuable very early pear.

Lawson-Tree healthy, a strong grower, early bearer and profitable sort. Of splendid quality for a very early pear. It colors beautifully. Red cheek with yellow shading.

Le Conte-Tree very vigorous and productive, partaking of the nature of the Chinese Sand Pear, of which it is a seedling. Fruit large, skin smooth, pale yellow. Quality fair. Ripens about with Bartlett.

Madeleine-M e d i u m; yellowish-green very juicy, melting, sweet. A fair grower and productive. August. D. $\& \mathrm{~S}$.

Manning's Elizabeth-Small to medium; bears in clusters; crimson and gold color; very beautiful; melting, rich, sugary, sprightly, perfumed; flavor excellent. August.

Osband's Summer-Medium; y e $110 \mathrm{w}$, with red cheek; half melting, mild and pleasant; fine flavor and excellent. A fair grower and productive. August. 
Petite Marguerite-Medium size; skin greenish--yellow, with brownish-red cheek and covered with greenish dots. Flesh fine, melting, juicy, vinous and an early and abundant bearer. Succeeds admirably as a Standard or Dwarf. August or September.

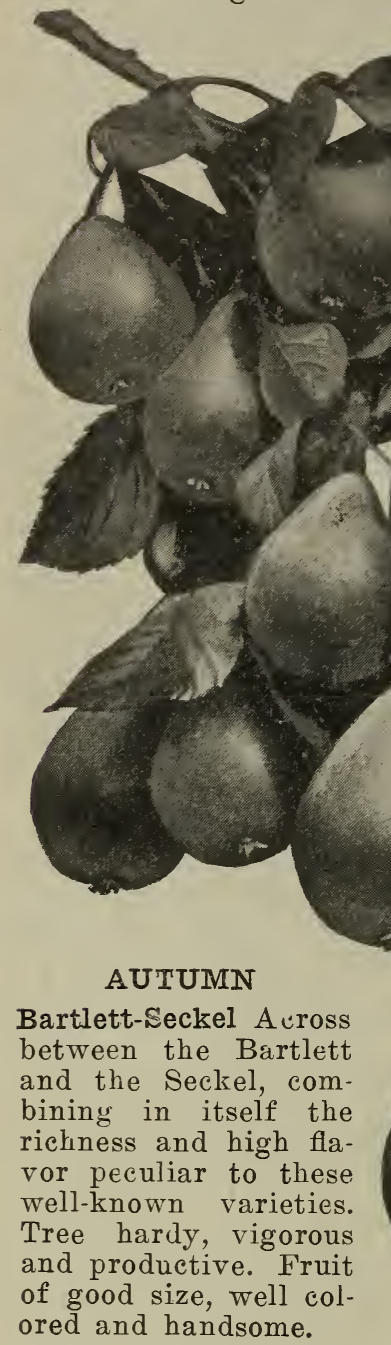

Buffum-Medium size; yellow, somewhat covered with reddish-brown and russet; buttery, sweet and excellent. A stout and upright grower. D. \& S.

Duchess d'Angouleme--Very large; greenish-yellow, sometimes a little russeted. Makes a beautiful tree. Does best on quince. One of the best. October and November. $D$.
Rossney-A new and excellent pear, raised from seed at Salt Lake City, Utah. In size medium to large; very fine grain, flesh melting and juicy; very sweet. Ripens two weeks after Bartlett.

Souvenir du Congress-Imported from France and of great promise. Fruit large and exceedingly handsome; beautiful yellow with bright red in the sun; melting and juicy with a musky flavor, rather tender. September. S.

Tyson-Rather large, bright yellow, with brown cheek; melting, sweet and delicious. September. D. \& S.

Wilder-Handsome, melting, sweet, pleasant and of the best quality for an early pear. One of the best keeping pears.

\section{AUTUIMN}

Belle Lucrative - (Fondante d'Atonne)-A fine large pear; yellowishgreen, slightly russeted; melting and delicious. Good grower and productive. September and October. D. \& š.

Beurre Bosc-Large; yellow russet; half melting, high flavored and excellent. September and October. S.

Beurre Clairgeau - Very large, pyriform; yellow and red; nearly melting, high-flavored. Tree a very good grower, an early and abundant bearer. A magnificent market fruit. One of the finest acquisitions. October and November. D. \& S.

Beurre d'Anjou-A large, fine pear, buttery and melting, with sprightly, vinous flavor. Tree a fine grower and sood bearer. October to $J$ inuary. D. \& S.

Columbia - See Bartlett-

AVORITE Seckel.
Early Harvest-(Chambers' or Kentucky)-Originated in Maryland, and valued as a profitable early variety. The best and most profitable market pear of its season. Fruit medium to large; rich golden-yellow, with red cheek next the sun, thickly covered with gray dots. August. D. \& S.

Eastern Belle-Originated near Bangor, Me. Seedling of Belle Lucrative, which it somewhat resembles; hardy enough to endure the cold of all North. ern sections. Flesh juicy, rich and melting, with a musky flavor. Septem. ber. S. 
Flemish Beauty-Large, beautiful, juicy, melting, rich and fine. Strong grower and good bearer; hardy everywhere. September and October. D. \& S.

Howell-Large, light waxen yellow, with a fine red cheek; handsome, rich, sweet, melting, perfumed, aromatic flavor. Tree an upright free grower, an early and profuse bearer. Very hardy and valuable. September and October. D. \& S.

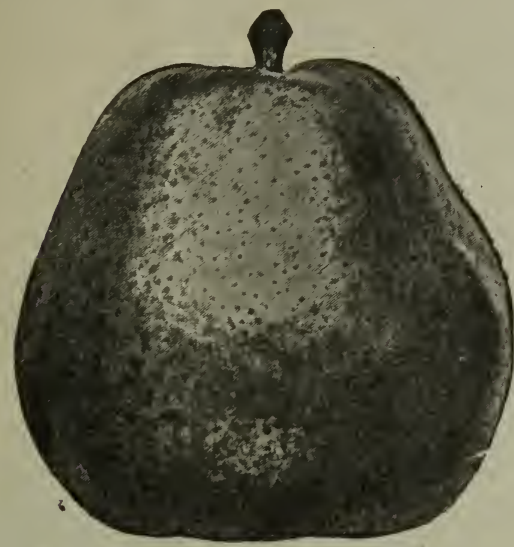

DUCHESS D'ANGOULEME

Idaho-Size large, nearly globular, obtusely ribbed; color light rich yellow, surface covered with many smail dots; cavity very deep and narrow and strongly furrowed; stem small and calyx closed; flesh white, fine-graired, buttery, melting and rich. September and October.

Louise Bonne de Jersey-Rather large; greenish-yellow, with a bright-red cheek; juicy, buttery and melting; excellent. V'ery productive; a fine grower on both pear and quince. September and October.

Onondaga-(Swan's Orange)-A very large, melting and highly-flavored yel low pear. Vigorous and proauctive. October and November. D. \& S.

President-Raised by Dr. Shurtleff, of Massachusetts, where it is very popular. Fruit large, roundish, obvate; somewhat irregular; flesh yellowishwhite, rather coarse, juicy, slightly vinous. Good. Early in November.

Rutter-Fruit medium to large, and nearly globular; skin rough, greenishyellow, sprinkled with russet; flesh white, moderately juicy, nearly melting, sweet, slightly vinous. Tree mod. erate grower and good bearer. Very good. October and November.

Seckel-Small; rich yellowish-brown; one of the best and highest flavored pears known. Productive. September and October. D. \& S.
Sheldon-Medium to large; yellow and red; very excellent. From Wayne County, N. Y. Tree a fine grower and productive; must be double worked to grow on quince. October.

Vermont Beauty-A most desirable pear. The fruit is of medium size, very handsome, being yellow with a bright carmine cheek; the flesh is rich, juicy, aromatic, of the best, and almost equal to the Seckel. Ripens immediately after the Seckel.

Worden-Seckel-Originated in Oswego County, N. Y. It is a seedling of the Seckel, and is equally as good in quality as that variety and more juicy, with an aroma equally as rich and inviting, while in size, color, form and appearance it is decidedly superior. The color is yellow with light red on the sunny side. Tree hardy and an enormous bearer, and the fruit is ripe just after the Seckel. All lovers of good pears should have trees of this variety.

\section{WINTER}

Beurre Easter-Large; p a le yellow, sprinkled with round dots, often dull red cheek; quality good. One of the best Winter Pears. Keeps all winter. Best on quince. D.

Duchess de Bordeaux-Large size, wlth very thick tough skin, which renders it very valuable keeper for winter use; flesh melting, juicy, rich; keeps till March. S.

Glout Morceau-Large; sweet, melting, juicy and buttery. One of the best early winter pears. Vigorous and productive. D.

Josephine de Malines-Medium; yellow, slightly russett; flesh buttery, juicy and sweet; a fine keeper. Productive; a poor grower. December to March. D.

Kieffer's Hybrid-Tree a remarkable grower, with so vigorous a constitution that it rarely if ever blights. Fruit of fine size, rich color and good quality. Brings high prices in competition with other varieties. Best when picked at maturity and house ripened. October and November.

Lawrence-About medium; yellow, thickly dotted; with a very fine, rich flavor; one of the best. Tree a moderate grower and very productive. December to January. S.

Lincoln Coreless-A remarkable late winter pear, from Tennessee. Keeps well until middle of March. Very large, handsome appearance, good quality, and with but few if any seeds. This pear is distinguished for its very small amount of core and seed, some specimens being almost entirely without either. Color golden yellow. Tree a good grower and very productive. 
Mount Vernon-Medium to large; of rich, russet color; flesh juicy, rich, melting, with a spicy flavor. November to Januáry. D. \& S.

President Drouard-A very good looking and large winter pear, ripening from March to May with a delicate and abundant perfume; melting and juicy. The tree grows vigorously; succeeds well as Dwarf. D. \& S.
Vicar of Winkīeld-(Le Cure)-Large, long, not first quality, but desirable for its productiveness. Best on quince. November to January. D. \& S.

Winter Bartlett-A new and valuable sort; much like the Bartlett, but later.

Winter Nellis-Medium in size; yellowish-green and russet; fine-grained, melting, rich and delicious; one of the best winter pears. Tree straggly, slender grower, but very productive. December. S.

\section{CHERRIES}

There are few more desirable trees than the Cherry. It may be planted near the street, or used to line avenues as an ornament, and it will at the same time produce an abundance of delicious fruit. This may be eaten out of hand, preserved, or it will find a ready'market at highly profitable prices for shipping, canning, etc. The trees thrive in any well-drained location. The Duke and Morello, or acid varieties, are thoroughly hardy, while the Heart and Bigarreau, or sweet sorts, will successfully resist very cold weather and may be grown in most places.

The Cherry may be grown for market with great profit. Many varieties are regular and abundant bearers, and fruit commands a good price in the market.

\section{HEART AND BIGARREAU CHERRIES}

Bing-This grand new Black Cherry was originated by Seth Luelling, of Milwaukee, Oregon. One-half larger than Luelling (Black Republican). Flesh very solid, flavor of the highest quality. Tree thrifty, upright grower, very hardy and productive. A tine shipping and market variety.

Black Eagle-Large, black; very tender, juicy, rich and high flavored. Vigorous grower and productive. First to fifteenth of July.

Black Tartarian-Very large; bright purplish-black; half tender, juicy, rich, excellent flavor. Tree a vigorous grower and productive. Last of June or July.

Centennial-A new white cherry and should be planted by everyone.

Coe's Transparent-Medium size; pale amber, red in the sun; tender and juicy, rich, handsome; one of the best. Strong grower; productive. Last of June.

Compass Cherry-A. cross between the Rocky Mountain Cherry and the $\mathrm{Na}$ tive Plum, and resembles both. The most remarkable fruit of recent origination. Hardy as any wild plum. Sweet, juicy and excellent flavor. Marvelously prolific bearer. Grows on any soil. Fruits every year-never misses. Bears second year after planting. Good shipper and fine cooker. The only cherry that is perfectly hardy in Minnesota, Wisconsin, Iowa, the Dakotas and Montana.

Downer's Late Red-Large; light red; tender, juicy and delicious. Vigorous and productive. Middle of June.

Dikeman-Large, black, sweet, solid and meaty. Tree vigorous grower. Its lateness makes it the most desirable.
Early Purple Guigne-(Early Purple)The earliest fine variety; . medium, heart shaped; tender, juicy and sweet. Tree rather a slender grower, but very hardy and productive. First to middle of June.

Elton-Large and fine flavor; pale yellow, light red next the sun. Vigorous grower. Last of June.

Governor Wood-Very large, rich; light yellow with red cheek; juicy and sweet. One of the verv best. Late in June.

Knight's Early Black-Large; black, tender, juicy, rich and excellent. Good grower and productive. Middle to last of June.

Lambert-Size very large, form roundish heart-shaped cavity medium, stem long, surface smooth glossy color dark purplish-red, with numerous minute indented russet dots, flesh dark purplish-red, meaty and of firm texture, stone oval, semi-cling, small for so large a fruit, flavor sweet or very mild sub-acid, aromatic, rich, quality very good.

Luelling-(Black Republican)-A native of Oregon. Fruit very large, shining black; flesh very solid and firm, fine; a good keeper and will bear transportation well. Tree a moderate grower and rather tender; an early and profuse bearer.

Napoleon Bigarreau-Very large; pale yellow or red; firm, juicy and sweet. Vigorous grower and very productive; one of the best. First of July.

Rockport Bigarreau-Large; pale amber with clear red; a very excellent and handsome cherry. Good grower and bearer. Last of June. 
Sand-Ripens in September; fruit good for general use; originated in the Sandy Desert, but grows well and is hardy in West Virginia; grows three feet high and spreads out right at the ground, and no climbing to get the cherries. Bears from two to four years old. Free from knots or any other defects.

Schmidt's Bigarreau-A most promising cherry; fruit of immense size, of rich deep black; flesh dark, tender, very juicy, with a fine flavor; bears abundantly and makes a most noble dish for the table.
Windsor-Seedling, originated at Windsor, Canada; fruit large, liver-colored; flesh remarkably firm and ol fine quality. Tree hardy and very prolific. A valuable late variety for market and for family use.

Yellow Spanish-Large; pale yellow, with red cheek; firm, juicy and excellent; one of the best light colored cherries; vigorous and productive. Last of June.

\section{DUKE AND MORELIO CHERRIES}

These, for the most part, are round-headed; fruit generally acid, though some varieties have a very rich, pleasant flavor. The trees are naturally of a smaller growth than the preceding class and well adapted for Dwarfs or Pyramids. The Morellos are more slender and spreading in habit than the Dukes, which are of stocky upricht growth. Both are more hardy than the Hearts or Bigarreaus, and in large demand where the latter cannot be grown to advantage.

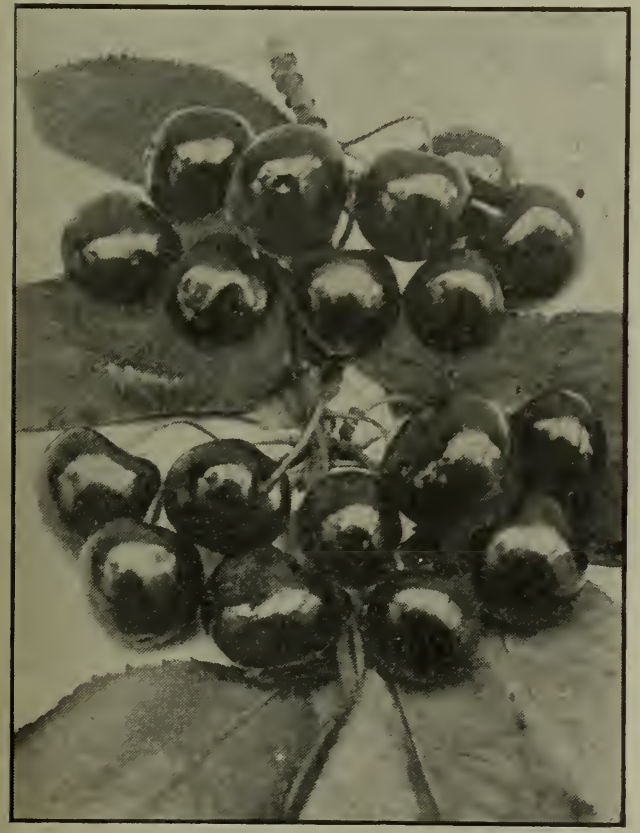

Baldwin-Tree upright vigorous grower, forming round head; leaves large, broad; fruit large, almost round, very dark transparent wine color; flavor slightly acid, yet the sweetest and richest in the Morello type; unexcelled in earliness, vigor, hardiness, quality and productiveness.

Belle Magnifique-Fruit large, roundish; skin bright red; flesh tender, juicy, sprightly sub-acid; one of the finest of this class of cherries. Tree hardy, vigorous and very productive. Ripens last of July.
Brusseler Braune-New; latest. of all cherries. Originated in Europe. Very hardy, wonderfully productive; dark brown-red; very large and handsome. The most profitable market variety in cultivation. A strong grower and better bearer than Early Richmond; fruit much larger.

Dyehouse-Partakes of both the Duke and Morello in wood and fruit; a very earı $\nabla$ and sure bearer; ripens a week befoie Early Richmond, of better quality aud quite as productive.

Farly Richmond-Medium size; dark red; melting, juicy, sprightly acid fisvor. This is one of the most valuable aud popular of the acid cherries, aud is unsurpassed for cooking purposes. Tree a slender grower, with a roundish, spreading head, and is exceedingly productive. The most hardy of all varieties, uninjured by the coldest winters when almost every other variety has been killed. Ripens through June.

Empress Eugenie-Fruit large, dark red, very rich, tender and sub-acid. Tree heads very low. Ripe about July 1st.

English Morello-Medium to large; blackish-red, rich, acid, juicy and good. Very productive. August.

Ida-Originated in Pennsylvania, and there well tested and grown extensively; ripening with the May Duke, and tree equally as hardy. The hardiest sweet cherry known. Quality excellent.

Late Duke-Large; light red, late and fine. Last of July.

Leib-A new Morello, one week later than Early Richmond, and claimed to be very superior. 
Louis Philippe-Large size; flesh red, tender, juicy, with mild sub-acid flavor. Very vigorous and productive. Of great value. A native of France.

May Duke-Large; red, juicy and rich; an old excellent variety. Vigorous and productive. Middle of June.

Montmorency Ordinaire - A beautiful large, red acid cherry, larger and finer than Early Richmond and fully ten days later. Being extraordinary prolific and hardy, it can be recommended as a variety of great value. Tree a free grower.

Montmorency Large-A large, red acid cherry; larger than Early Richmond and fully ten days later.

Olivet-A new Duke, of French origin. Unlike most others of this class, it is said to be very early and to ripen over a long period. Fruit very large, globular, and of a deep shining red; tender, rich and vinous, with a sweet subacidulous flavor.
Orleans Cherry-One of the best sour cherries for cooking and shipping purposes. Ripens with Large Montmorency. Keeps well, and is loaded with fruit every year. Free from black knots and bears very young.

Ostheim-A hardy cherry from Russia. It has been tested in the severest winters of Minnesota and has been found perfectly hardy. Fruit large, roundish, ovate; skin red; dark at maturity; stalk long; flesh liver-colored, tender, juicy, almost sweet.

Reine Hortense-Very fine; large, brightred, juicy and delicious. Vigorous and productive.

Wragg-Fruit large, bright-red, translucent; stalk long; flesh firm, rich, sweet, excellent.

\section{IMPROVED ROCKY MOUNTAIN DWARF CHERRY}

From Colorado where it has been under cultivation for some time and receivel the highest endorsement from the leading horticulturists and fruit growers of that staie. As hardy as a Wyoming sage bush, it has withstood a temperature of 40 degrees ripe and in size averages somewhat larger than the English Morello, its season of quarts having been picked from a three-year-old bush. The fruic is jec black when ripe and in size averages somewhat larger than the Engiion Morello, its season of ripening being after all others are gone.. In flâvor it is akin to the sweet cherrıes. Worthy of cultivation for an ornamental shrub. When in bloom will grace any lawn with its mass of white flowers.

\section{PLUMS}

The plum, like the pear and other fine fruit, attains its greatest perfection on heavy soil. The curculio, a small, dark-brown beetle, often stings the fruit, causing it to drop off, but the following directions, faithfully observed, will secure a crop of this splendid fruit everywhere.

As soon as the blossoms are fallen, spread two sheets under the tree, and give the tree a sudden jar by striking a smart blow with a hammer upon the stub of a limb sawed from the tree for the purpose; the insects will drop on the sheets and can be killed. Collect all fallen fruit and burn or feed the swine. Repeat the operation every day for two or three weeks. It should be done before sunrise.

The cost of protecting entire orchards from the attacks of this enemy will not exceed ten cents per tree for the entire season.

Black knots should be cut out when they appear, and the disease will soon be conquered.

Abundance-Large; bright red with yellow cheek; flesh light yellow, very juicy, tender, with delicious sweetness; early, annual, profuse bearer. September.

Aikin--(Nigra)-Found wild in Atkin County, Minnesota, (near Lake Itasca) Flesh, yellow, rich, tender, juicy and sweet. Stone remarkably thin and almost free. Of splendid market quality, especially on account of earliness.

Beauty of Naples-A new variety, of the highest promise; size large, color greenish-yellow, flesh firm, juicy and very fine flavored. Tree very hardy and prolific. Middle of September.

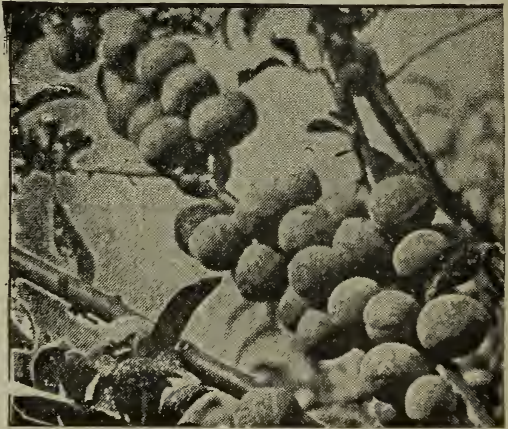

ABUNDANCE 
Botan-Lemon-yellow ground, nearly overspread with bright cherry and heavy bloom; large to very large; oblong, tapering to a point like Wild Goose; flesh orange-yellow, melting, rich and highly perfumed. August.

Bradshaw-Fruit very large, dark violetred; flesh yellowish-green, juicy and pleasant. Tree vigorous, erect and productive. Middle of August.

Berckman's-A fine Japan plum. Tree of remarkable vigor, with long, spreading, willowy branches; exceedingly productive, and when well thinned grows to large size. Obtuse, conical; deep bloodred when ripened in the sun; moderately juicy, excellent quality. Ripens with A bundance.

Burbank-Large, globular. Cherry-red, mottled yellow color; flesh yellow; melting, juicy, sweet; semi-cling. One of the best. Ripe July 1st to 10 th.

Charles Downing-Vigorous, healthy tree. Fruit large, handsome and excellent. One of the best of the Wild Goose type.

Chabot-(Japan)-A splendid plum. Flesh sweet and of excellent flavor. Ripens about the middle of August, when all other plums are gone.

Cheney-(Nigra)-Fruit irregular, oval, medium to large; color a dark and rather dull red with slight blue bloom, skin thick; flesh yellow and firm; stone large, pointed, oval, much flattened, cling. Season early.

Coe's Golden Drop-Large and handsome; light yellow, firm, rich sweet; one of the best of late plums. Last of September.

De Soto-(Americana) - Probably the most grown of any plum of the American group. Quality unsurpassed and productiveness almost too great; tree should be well fed and the crop thinned to prevent overbearing and improve size of fruit. Season medium. Fruit, medium; orange overlaid with crimson; flesh yellow and firm; of fine flavor and quality. Has been found a profitable market variety and excellent for all home uses.

Empire State-Origin, Central New York. Tree thrifty, healthy and hardy, a regular and profuse bearer. Fruit of extra large size, good quality. Unsurpassed for home use and unequalled for market.

Fellemberg-(Italian Prune) - A fine late prune; oval, purple; flesh juicy and delicious; parts from the stone; fine for drying. Tree very productive. Sept.

Forest Garden - (Americana) - Fr u i t large, nearly round, dull purplish red with thin bloom; flesh yellow, sometimes reddish next the stone; firm, sweet and of pleasant flavor; cling. Season medium.
General Hand-Very large, oval; goldenyellow; juicy, sweet and good. First of September.

German Prune-A large, long oval variety, much esteemed for drying; color dark purple; of very agreeable flavor. September.

Giant Prune-(California)-The largest prune known, the fruit averaging $11 / 2$ to 2 ounces each. Its unequaled size, handsome appearance, rare keeping qualities, great productiveness and high quality places it at the head of the prunes for home use or market.

Grand Duke-Fruit oval with a short neck. Skin dark, almost a darkishpurple, but reddish when shaded and covered with blue bloom. Flesh green: ish-yellow, adhering closely to the stone; very brisk, with a sweet and rich flavor when fully ripe.

Green Gage - Small; considered the standard of excellence; slow grower. Middle of August.

Guii-Extensively grown for market, having proved to be one of the most profitable for that purpose. Tree a hardy, very strong, vigorous upright grower, spreading with age and bearing; an early and abundant bearer. Fruit large, roundish, oval; skin dark purple, covered with a thick blue bloom; flesh pale yellow, a little coarse, rather firm, juicy, sweet, sprightly, sub-acid; free-stone. Season last of August and first of September.

Hale-New; a very handsome, large, round plum. Best of all Japanese sorts. Very late.

Hytankayo-(Japanese)-Large to very large. Commences to ripen immediately after Wild Goose; larger than the Wild Goose and of a meaty character, much finer and better shipper. Conical in shape; color deep purplish-red, slightly mottled when over ripe; flavor good, sub-acid. Tree inclining to dwarf.

Imperial Gage-(Flushing Gage, Prince's Imperial Gage)-Fruit large, oval; skin pale green, flesh juicy, sweet, rich and excellent. Tree very vigorous and productive. Middle of August.

Jefferson-Large, yellow, reddened in the sun; juicy, rich and delicious; one of the best. Last of August.

Lincoln-This is said to be one of the most remarkable plums yet introduced. The largest of all the hardy varieties, specimens of the fruit weighing as much as four ounces each; it is of the finest quality, even surpassing its parent, the Green Gage. It ripens early, is wonderfully prolific, and is curculio proof. 
Lombard-Medium, round, oval, violetred; juicy, pleasant and good; adheres to the stone. Tree vigorous and productive. Last of August. A valuable market variety; one of the most hardy and popular.

Magnum Bonum, Red-(Egg)-Large; red, firm flesh, sub-acid. First of September.

Magnum Bonum, Yellow-(Egg)-Large; yellow; fine for culinary purposes. Last of August.

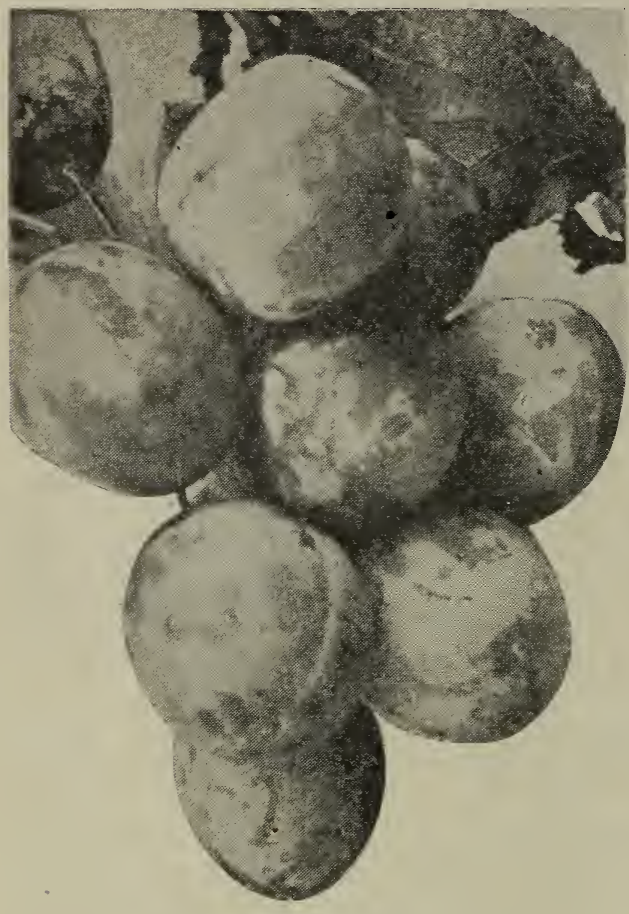

MONARCH

Marianna-An accidental seedling originated in Texas. An unusually strong, rapid grower. Fruit larger than the Wild Goose. Round and of a peculiar light red color. Its productiveness is marvelous, and it ranks among the best, if not the best of the Chickasaw varieties. August.

Milton-Perfectly hardy; a great bearer of fine fruit. The earliest plum in the world-ripening July 10th. Resembles Wild Goose in appearance very much.

Miner-An improved variety of the Chickasaw; originated in Lancaster, $\mathrm{Pa}$. Medium size, oblong, pointed apex; skin dark purplish red, slightly mottled, with fine bloom; flesh soft, juicy, vinous; adheres to the stone. Excellent for canning and cooking and esteemed for market in the West. Tree hardy, vigorous and productive. Early in October.
Monarch-Tree very thrifty, hardy, healthy and handsome. Fruit largest size often six inches in circumference; dark purple nearly round; flesh pale yellow, parts freely from stone, pleasant, juicy and first rate quality: An early and regular bearer.

Moore's Arctic-Size medium or below; skin purplish black, with a thin blue bloom; flesh greenish--yellow, juicy, sweet and pleasant flavor. Is claimed to be the hardiest plum grown and so far free from black knots. Tree healthy, vigorous; an early and abundant bearer.

Niagara-A vigorous productive variety; valuable both for dessert and cooking; fruit large and handsome, remaining well on the tree; flesh juicy, rich and fine flavored. Last of August.

Ogon-Fruit large, round, bright goldenyellow, with faint bloom and some red on the sunny side; flesh firm, sweet, rich and dry. Tree vigorous and hardy. August.

Peach-Very large and handsome; dull red, good, very productive. Last of August.

Pond's Seedling-A magnificent English plum; light red, changing to violet; flesh rather coarse. Tree a good grower and an abundant bearer. One of the most attractive trees in cultivation.

Pottawattamie-A cross of Chickasaw and Swedish Sloe. Quality excellent; an immense early annual bearer; curculio proof. Tree perfectly hardy; a strong, vigorous grower; most profitable tree for the fruit grower.

Prince's Yellow Gage-Rather large, golden yellow; flesh rich, sugary and melting; very hardy and productive; a favorite sort. August.

Prunus Simoni-(Apricot Plum)-A distinct species from China. Growth erect, flowers small, white, appearing early in spring; fruit large, flattened, of the size and appearance of a Nectarine, and of a brick red color; flesh yellow, with a peculiar aromatic flavor.

Quackenboss-Large oblong, oval, deep purple, a little coarse; sprightly, juicy, sweet and excellent; adheres slightly to the stone. Tree a rapid upright grower and productive. Valuable for market. October.

Red June-(Red Nagate)-Medium size, pointed; color deep red-purple; flesh yellow; quality good; eling. A good market variety.

Reine Claude De Bavay-Large, greenishyellow, spotted with red; firm, juicy, sugary, and of fine quality; very productive. September. 


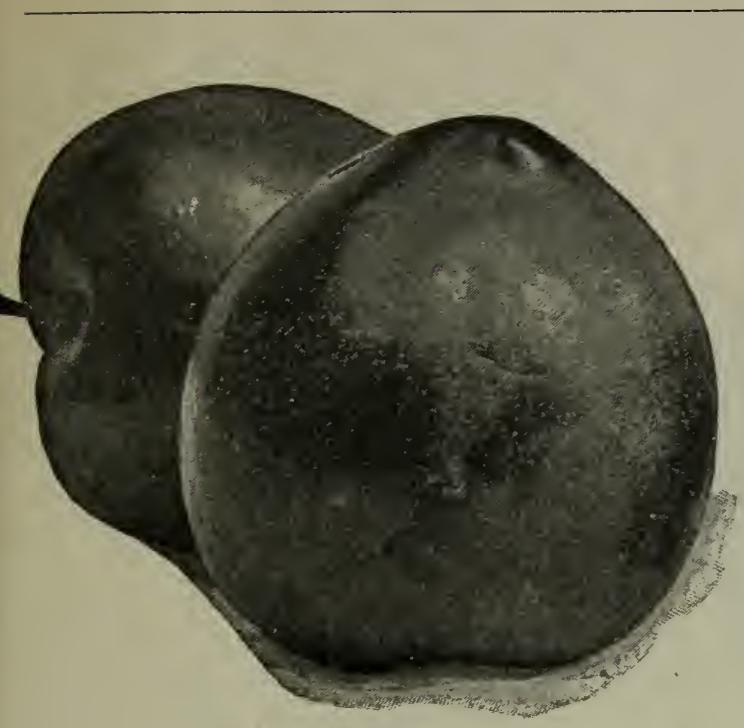

SURPRISE

Satsuma-Native of Japan-The tree looks much like the Wild Goose, and is not likely to prove more hardy than Kelsey. The fruit has a pleasant flavor, and unlike all others, has red flesh with a remarkable small stone.

Shipper's Pride-The fruit is of a large size, it being no uncommon occurrence to find specimens measuring two inches in diameter each way, as it is nearly round; a semi-cling, of a handsome, dark purple color; excellent for canning and an unusually good shipper, arriving at its destination in good order, and keeping a long time in excellent condition.

Shropshire Damson-(or Prune Damson) -An English variety of great merit for preserving. Large, and much more desirable than the common Damson. Tree vigorous grower, very free from attacks of curculio; hardy and an abundant bearer. October.

Spaulding-Tree a strong grower, with broad, rich, dark foliage; fruit large, yellowish green with marblings of deeper green and a delicate white bloom; flesh pale yellow, very firm, sprightly, sugary and rich; fine for canning. Claimed to be curculio proof.

Stanton-Originated in New York State. The tree is a vigorous, healthy grower; fruit medium to large, nearly. round, deep purple with blue bloom; quality best. Ripens and keeps rather late.

Stoddard-One of the largest of the native plums. Originated in Iowa. Light pinkish-red color and very handsome, with a tough, sweet skin; excellent quality.
Surprise-(Hortuıana) - A variety introduced about 1899 by Mr. Martin Penning of Sleepy Eyє, Minn., and it is said by many to be the finest in quality of any of the cultivated varieties in the native Minor group, also the hardiest of that type. Fruit large to very large; skin medium, thick, tender; bright red; flesh pale yellow, meaty and of fine flavor; quality extra good. Season medium. Tree an upright, vigorous, healthy grower and is everywhere reported very productive. A splendid variety for either home or commercial culture and should be found in every collection.

Tatge-Evidently a seedling of the Lombard. It is larger, more nearly round, darker in color and finer quality than that well known and excellent variety. Claimed to be the hardiest, most productive and longest-lived plum known.

Turkish Prune-The largest and decidedly the best of the prune family and very like the Italian Prune in most respects. Splendid for drying, canning or using fresh.

Tennant Prune-Originated in Oregon. Very promising on the Pacific Slope. If it does equally well in the East it will equal or surpass in all respects our largest and best prunes.

Washington - Large, green, somewhat reddened; juicy, sweet and fine; very productive. Last of August.

Weaver-This remarkable plum was found near Cedar Rapids, Iowa, grow. ing in the old Indian camping ground. Flesh firm, with flavor resembling the Apricot. As a substitute for the peach it has no rival. Curculio proof.

Wickson Japan-Very large, growing carmine, with a heary white bloom; flesh firm, sugary, delicious; stone small. Remarkable for its long keeping qualities. Tree of vigorous, upright growth.

Wild Goose-An improved variety of the Chickasaw, evident in the great vigor of the tree and increased size of the fruit which is nearly as large as the Green Gage. Skin purple, with a bloom; flesh juicy, sweet and adheres to the stone. Last of July.

Willard-Medium size, round, not pointed; color dark, clear red, with minute yellow dots; yellow-fleshed, sweet and of a fair quality. The tree is very dis. tinct and hardy and matures the foli. age earlier than any other Japanese variety, which is quite an important feature with this race of plums. 


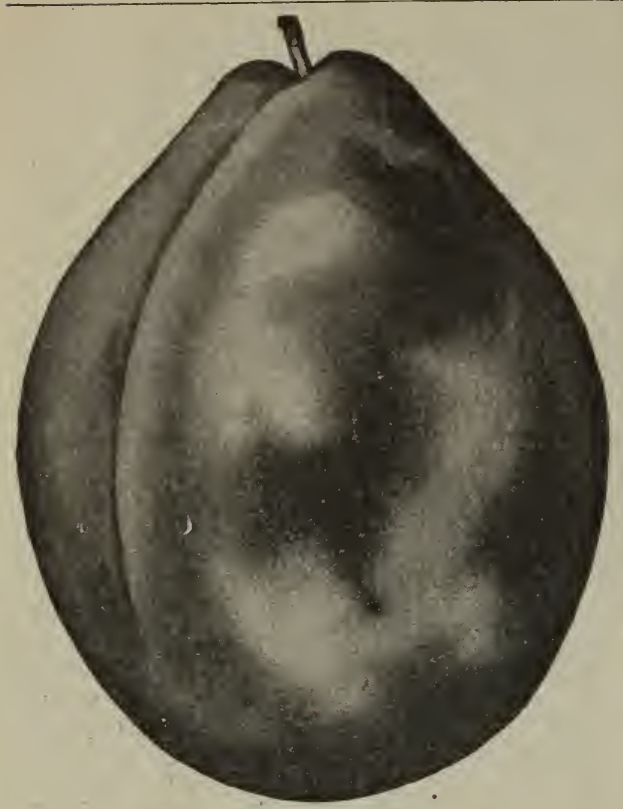

Wolf-This is an enormous bearer and bears annually. Fruit large and of good quality; color bright red. Splen. did for eating.

Wyant-(Americana)-Fruit medium to large, slightly oblong; color purplishred, inclining to orange on shaded side; stone semi-cling; skin thick; flesh rich yellow sometimes red next the stone; quality good. Tree is a spreading grower and is reported very prolific. It is certainly a splendid plum for both home and market use.

Yellow Egg-(White Magnum Bonum, White Egg Plum)-Fruit of the very largest size; skin yellow, with numerous white dots; flesh yellow, rather coarse, sub-acid; fine for cooking. Tree vigorous and productive. Last of Aug.

TENNANT PRUNE

\section{NEW JAPAN PLUMS}

\section{Introduced by Luther Burbank}

Apple-Is a wonderful keeper; tho most luscious and delightful plum we ever tasted; nothing could be better. Its great size, vigorous growth of tree and perfect imitation of an apple, as well as beauty of color, will make it most valuable.

America-This giant plum originated from seed of the well known "Robinson" from a cross with the Japanese plum "Botan," and is from the same combination which produced "Gold", and "Juicy," both of which have, proved generally hardy throughout the United States, and no doubt America will prove quite as hardy. Color, coral red.

Bartlett-Nothing like this latest wonder, the Bartlett Plum, has ever before been produced, and the world of fruit growers who so expectantly wait for the magical productions will here read of the marvel for the first time. A wonderful combination of fruit is this, in reality a plum, but in quality almost the exact counterpart of the pear from which it is namea.

Chalco-The fruit, which ripens just before Burbank, is large, flat like a tomato, deep reddish-purple, with very sweet, rather firm, exceedingly fragrant, yellow flesh and a small seed. Like the Apricot Plum, the fruit is almost as stemless as a peach, and completely surrounds the older branches as thick as it can stick, like kernels on a huge ear of corn.
Climax-Cross of Simoni and Botan. Very large, measuring $63 / 4$ by $71 / 2$ inches in circumference; heart-shaped; a superbly rich plum, extremely early - ripens in the coast countries early in July, before any other good pium. Color of flesh yellow; sweet and delicious, with a pineapple fragrance.

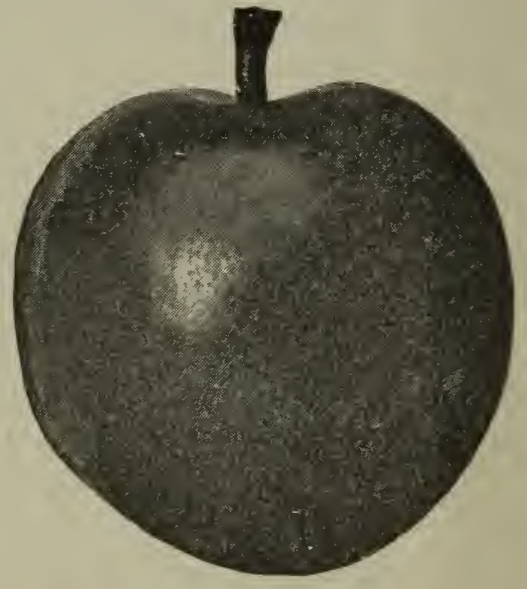

CLIMAX

Maynard-In size it is very large, often measuring seven and one-half inches in circumference. From nearly round, slightly.flattened at the ends, of richest crimson-purple, deepening to roval damask as full ripeness is reached. Tree hardy, vigorous and compact srower. Leaves dark glossy green. Bears im- 
mense crops of even sized fruii while very young; never fails. Surpasses all other varieties in keeping aud carrving qualities. Flesh firm, even when dead ripe, but melting and juicy, with a deliciousness indescribable. Will command the highest price in both home and foreign markets.

October Purple-It is a splendia grower; ripens up its wood early to the tips; bears enormously every season; fruits "all over" the old wood on srurs, instead of away out on the branches like many other varieties. Fruit very uniform and large, many specimens measuring over seven inches in circumference. It is a superb late variety.
Shiro-From Wickson and Robinson. Fruit egg-shaped, medium size, suture indistinct; smooth, bright yellow, transparent; bloom thin, white; cling; qual. ity good. Remarkable for its great productiveness, rivaling the Burbank in this respect.

Sultan-It is a cross between Wickson and Satsuma. It is large, being over two inches in diameter and nearly round in shape. The surface is smooth, dark wine-red or garnet, being very handsome. The flesh is garnet color too, and rich looking. In flavor it is excellent, being tart enough, yet not sour, but a delicious sub-acid.

\section{PEACHES}

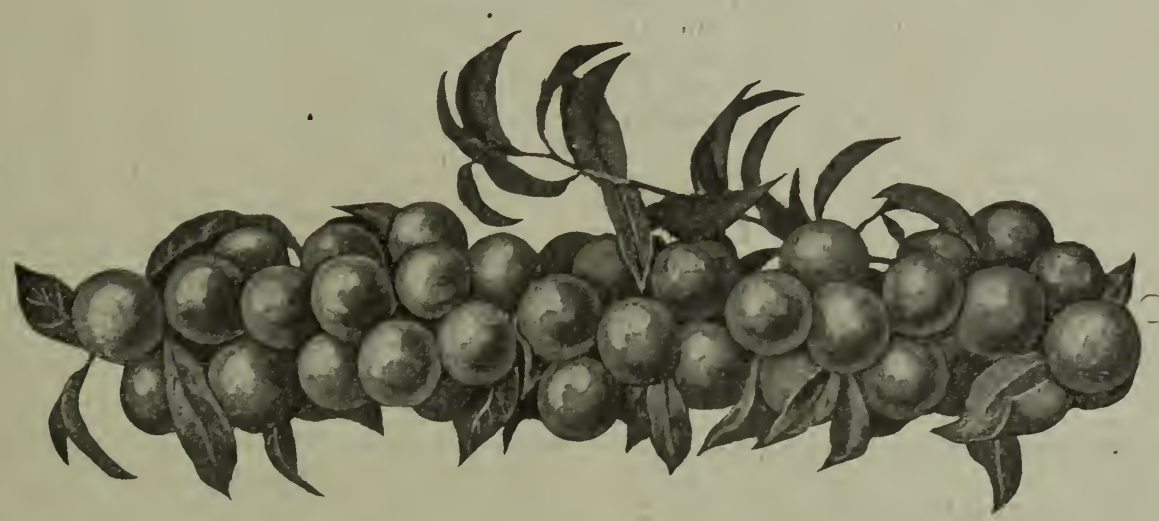

The ease with which Peach trees may be cultivated, their comparative freedom from disease, the short period before they become productive, with the immense demand for the fruit and the facility with which it may be shipped into distant markets, makes peach growing extremely profitable.

To secure healthy, vigorous and fruitful trees, the ground must be kept clean and mellow, and it should receive an occasional dressing of wood ashes. It should be remembered that peaches are all borne on wood of the previous season's growth, and that this makes it absolutely necessary to prane the trees yearly, to remove dead branches and to let in light and air, and keep the trees in good shape to produce bearing wood.

Admiral Dewey-This is another triumph in the production of very early peaches. There is no known variety that can complare with it in the qualities that go to make a desirable early market variety. Perfect freestone.

Alexander's Early-Medium size; skin greenish white nearly covered with rich red, flesh melting, juicy, sweet. Tree vigorous and productive. Ripens two weeks earlier than Hale's Early.

Amelia-Very large, conical; white, nearly covered with crimson; juicy, melting, vinous, sweet and of high flavor. July 1st to 10 th.
Amsden's June-(Amsden)-Originated at Carthage, Mo., in 1882. Medium size; skin greenish-white, nearly covered with purple in the sun; ripens with the Alexander and closely resembles that variety, but some think it a little higher flavor.

Barnard's Early-A fine yellow peach of good quality. Very popular in Michigan. An excellent canner.

Beer's Smock-Large to very large; yellow, with red cheek; flesh yellow and of the very best quality for the season; freestone. A regular and enormous bearer, making it very desirable for market purposes. Last of September. 
Baldwin's Late-Large, oblong; greenishwhite with red cheek; juicy and wellflavored. October 10th.

Belle of Georgia-Very large; skin white, with red cheek; flesh white, firm, and excellent flavor; the fruit is uniformly large and showy; very prolific bearer. A seedling of Chinese Cling.

Bokara, No. 3-Seventy-five per cent. hardier than any other peach. Imported by Professor Budd, from Bokara.

Capt. Ede-Originated in Southern Illinois, and among leading fruit growers considered one of the best orchard peaches. Ripens with Crawford's Early. Freestone. Very hardy. Yellow with Carmine cheek.

Carman-In size it is large; shape somewhat oblong, resembling its probable sister, the great Elberta, the tree also resembling this variety. Its color is pale-yellow, covered for the most part with a deep blush, while the skin is very tough; the flesh is quite juicy and tender with a fine flavor, and a freestone. Its time of ripening is exactly that of Early Rivers.

Chair's Choice-Bearing at four years of age four or five bushels of fruit; large size; firm, yellow; very handsome and of good quality. Ripens between Crawford's Late and Smock.

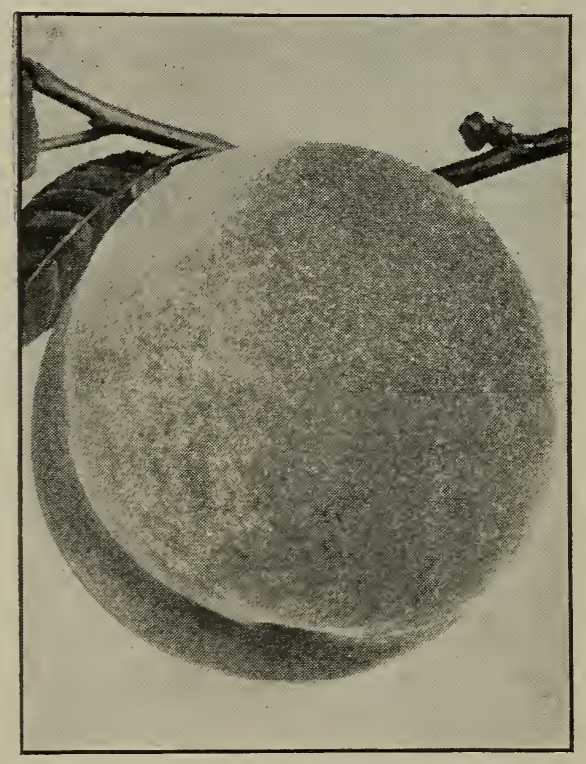

CHAMPION

Champion-Very large; many specimens measuring ten inches in circumference; creamy-white with red cheek; flavor delicious, sweet, rich and juicy; very hardy, productive. August. Free.
Chinese Cling-This type has of late years produced several improved seedlings, which, although not all attaining the enormous size of the original rariety, are, however, of better flavor and less predisposed to decay, and of less straggling habit of growth.

Cooledge's Favorite-Large, white with crimson cheek; flesh pale, very melting and juicy, with a rich sweet and high flavor; beautiful and excellent. Tree vigorous and productive. Last of Aug.

Crawford's Early-A magnificent, large, yellow peach of good quality. Tree vigorous and very productive. Its fine size, beauty and productiveness 'make it one of the most popular sorts; no other variety has been so extensively planted.

Crawford's Late - (Late Crawford) Fruit of large size; skin yellow, or greenish-yellow, with dull red cheek; flesh yellow. Tree vigorous, moderately productive; one of the finest late sorts. Last of September.

Crosbey-(Excelsior) - Originated near Lowell, Mass. Tree low, spreading, willowy habit of growth; fruit buds hardy, so that "Crosbey", produces full annual crops where others fail; fruit medium size, rich orange yellow, splashed with carmine on the sunny side; perfect freestone; pit small; flesh yellow, juicy, tender, sweet and rich. Middle of September.

Farly Canada - Originated at Jordan, Canada. As early as the earliest. Of good size, of firm quality and handsome appearance. Its earliness, origin, and the fact that the flesh cleaves from the stone almost as freely as with the later varieties, creates an unusual demand for trees of this variety.

Early Louise-Larger than Early Beatrice, very thin skin and delicate aroma; excellent variety for home consumption only, as it is too tender to carry great distances. Maturing from June 8 th to 15 th. Tree very prolific.

Early Rivers-Large; color creamy white, with a delicate pink cheek; flesh melting, with a remarkably rich flavor. Larger and ten days later than Alexander. One of the finest peaches for home use or near-by market.

Early Tillotson-Medium, white, covered with red, melting, good; very prolific, a favorite market variety; stands shipping well. Ripe from June 20 th to $25 \mathrm{th}$.

Flberta-The great market peach of the South and Southwest. It is perfectly hardy at the North, and is confidently believed by the most experienced fruit growers of the North to be one of the very best peaches for home use or market. Ripens with Crawford's Early. 
Everbearing-One of the most remarkable peaches of the season. The first ripening averages $31 / 2$ inches long by 3 inches broad. The size of the second and following crops diminishes gradually, until that of the last ripening is about two inches in diameter. A supply of the fruit may, therefore, be secured from the same tree for several weeks.

Fitzgerald-A seedling found at Oakville, Ontario, where it stands the winters perfectly, and for the past four years has cropped regularly. It is undoubtedly very hardy, and the fruit averages larger than any variety we know of. Quality first-class, freestone, and we recommend it with entire confidence.

Flaters, or Yellow St. John-Large roundish, orange-yellow, with deep red cheek; juicy, sweet and high flavored; flesh yellow; prolific, an excellent peach. It ought to have a place in every orchard. Middle of June.

Foster-Originated in Medford, Mass. Large deep orange red, becoming very dark red on the sunny side; flesh yel. low, very rich and juicy, with sub-acid flavor. Ripens with Early Crawford. Very handsome.

Garfield or Brigdon-A new peach, originated in Cayuga Co., N. Y. Flesh yellow, very rich and juicy; color deep orange-red. Middle of September.

Globe-A rapid, vigorous grower and enormous bearer; fruit very large globular in form; flesh firm, juicy, yellow, shaded with reddish crimson towards the pit or stone; quality good, very rich and luscious. September and October.

Golden Drop-Large, golden yellow, with red cheek in the sun; flesh yellow, juicy, rich and very good. Tree very hardy, productive. Ripens between Hill's Chili and Smock.

Governor Hogg-This most wonderful peach originated five miles north of Tyler, Smith County, Texas, and was discovered in 1892. It is one of the most valuable peaches known. Fruit very large, superior richness and flavor; white with red cheek; it resembles the Chinese Cling in size and color. A prolific bearer and vigorous grower.

Greensboro-The largest and most beautifully colored of all the early peaches. Of good quality; juicy; a freestone, but adheres slightly; ripens perfectly to the seed and with the Alexander, which makes it of great value as a market peach.

Hale's Early-Medium Size; greenishwhite, with red cheek; first quality. Tree healthy, good grower and productive. The earliest good peach we have and promises to be a leading orchard variety.
Heath Cling-(White Heath Cling)Originated in Maryland where it is much esteemed. Of large size and good quality.

Henrietta, or Levy's Late-Flesh yellow to the seed, to which it adheres slightly. Very sweet and sufficiently firm to bear transportation when fully ripe 1,000 miles in good order; flavor good with fine aroma.

Hiley-Very vigorous and hardy trees. Large fruit of rich, creamy white color, with rich blush on sunny side. Excellent quality. Freestone.

Hill's Chili-Tree very hardy; slow grower, great bearer; excellent; late.

Honest John-Medium to large, yellow; flesh yellow, of good quality. Tree vigorous and productive. First of September.

Indian or Blood-Large dark claret, with deep red veins; downy; flesh deep red; very juicy, vinous and refreshing. Middle of August.

Jacques Rareripe-Very large, deep yel. low; has a high reputation. Last of August.

Kalamazoo-(Free)-Medium to large, oval; yellow striped with red and thin bloom; flesh yellow, red at pit, rich, vinous and of good quality. A valuable sort.

Klondyke-The most remarkable peach in size, color and flavor of the age. This marvelous peach originated in York Co., Pa., from a pit of Old Mixon, pollenized by Heath Cling. Tree a strong, upright, robust grower, with large, long luxuriant foliage, a perfect picture of health; very productive.

Lady Ingold-Resembles Early Crawford, but of better quality and a few days later. Superior for canning.

Large Early York-Large; white with red cheek; fine grained, very juicy, rich and delicious; vigorous and productive; one of the best. Last of August.

Lemon Cling-(Cling)-Very large and beautiful lemon-shaped; light yellow with red in the sun; flesh firm, yellow and rich, sub-acid flavor. August.

Lemon Free-A new seedling, originated in Ohio; resembles somewhat the Smock Free, but is in every way finer, larger and of better quality. A regular and prolific bearer, with fruit sometimes measuring twelve inches in circumference, and of finest color and flavor. Ripens first of October. Freestone.

Lord Palmerston-Originated with the celebrated nurseryman, Thomas Rivers, of England. Fruit very large, skin whitish, with a pink cheek; flesh firm, melting, rich and sweet. Last of September. 
Mamie Ross-Seedling of Chinese Cling, which it resembles. Fruit of good size; skin white; flesh firm, juicy and of good quality.

Matthew's Beauty-Originated in Randolph County, Ga. Handsome appearance, round, golden yellow, with beautiful red cheek on the sunny side; perfect freestone; flesh firm. The best shipper. Tree is a heavy, stocky grower, its fruit buds and blossoms among the most hardy. Ripening at a time when the market is almost bare of fine fruit, is bound to be very profitable.

Mayflower-Earliest peach known. Ripens one week before Sneed; color red all over, beautiful appearance. Carries well to market not being tender like Sneed. Blooms very late, crop never entirely cut off by late frosts, size medium, quality good. Tree an upright good grower, a very prolific bearer. Originated in Copiah Co., Miss.

Michigan Early-Medium size; white, with red cheeks, handsome; flesh white, firm and of fine quality. An early and good bearer. Middle of August.

Mountain Rose-Large, red; flesh white, juicy, rich and excellent. One of the best early peaches, ripening with Troth's Early, and much larger and finer than that variety. Should be in every collection. First of August.

Morris White-Medium; straw color, tinged with red; juicy and delicious. Productive. Niddle of September.

old Mixon Cling-Large; pale yellow, with red cheek; juicy, rich and high flavored. One of the best clingstone peaches. Last of September.

old Mixon Free-Large; pale yellow with a deep red cheek; tender, rich and good. One of the best. First to middle of September.

Picquet's Iate-Very large; yellow, with red cheek; flesh yellow, buttery, rich, sweet and of the highest flavor. Maturity from end of August to middle of September. This variety seldom fails to produce a crop of fruit, one of the most profitable late yellow peaches South and West.

Ray-Above medium size; white flesh, with red blush; firm and good shipper and a good seller on the market. Trees are strong growers, noticeably so, compared with other varieties. A regular bearer. The fruit continues in ripening longer than any other variety we know, and we earnestly recommend that our customers plant this valuable Peach for profit in all commercial orchards.

Reeves' Favorite-Large, roundish; skin vellow, with a fine red cheek; flesh yellow, red at the stone; juicy, melting, with a vinous flavor. A good, hardy variety. September.
Slappey-Hardy sort. Ripens in June in Georgia. Is free of excessive rot and keeps splendidly. Flesh yellow, sweet, excellent flaror. Freestone.

Sallie Worrell-Very large; white. Very good. September.

Salway-Fruit large, roundish; deep yellow, with a rich, marbled, brownishred cheek, flesh yellow, firm, juicy, rich and Sugary. An English variety; prized highly as a late, showy market sort.

Schumaker-Fruit medium to large; juicy melting and rich. Parts freely from stone when fully ripe. Ripens midale of July.

Sneed-A good grower and productive. A profitable variety. Good quality. Color white, with red cheeks.

Snow's Orange-Medium; orange-yellow, with dark-red cheek; flesh yellow and of good quality. Hardy and very productive. Beginning of September.

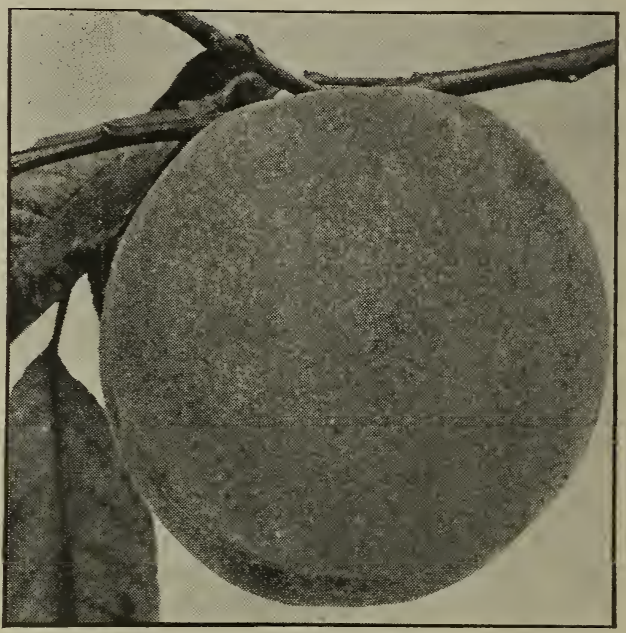

\section{STUMP THE WORLD}

Stump the World-Very large, roundish; skin white, with a bright red cheek; flesh white, juicy and good. Last of September.

Thurber-Large to very large; skin white with light crimson mottlings; flesh very juicy, vinous and delicate aroma; of exceedingly fine texture. Maturity middle to end of July.

Triumph-The earliest freestone and the earliest yellow-fleshed peach known. The greatest acquisition yet in a peach. Ripens with the Alexander.

Victor-The earliest peach known; ripening ten days earlier than the sneed. The tree is a very vigorous, compact grower and regular and immense bearer. The fruit is of a very pleasant, sub-acid flaror; equals the Alexander in size, ripens thoroughly and is a semi-cling. 
Waterloo-Of medium to large size; color whitish-green, marbled with red, deepening into dark purple crimson in the sun; flesh greenish-white, with an abundance of sweet, vinous juice; adheres some to the stone, like Amsden, Hale's Early, etc. July 14th.

Wheatland-Originated with D. S. Rogers, near Rochester, N. Y. Mr. R., who has large orchards, including the leading sorts, thinks this is the finest of all. Fruit large; color golden-yellow, with crimson tint flesh firm and of fine quality. Ripens between Crawford's Early and Late.
Wager-Large; yellow, juicy, and of a fair flavor. Trees produce fruit in great quantities. Last of August.

Wonderful-A freestone; color rich golden-yellow, overspread with carmine. It ripens after nearly all other varieties have disappeared, and is a remarkable keeper. Tree wonderfully prólific.

Yellow Rareripe-Large deep yellow, dotted with red; melting, juicy, with a rich flavor. Ripens one week later than Crawford's Early. Closely resembles Jacques' Rareripe.

\section{NECTARINES}

A most delicious, smooth skinned fruit, which thrives wherever peaches will grow, but is liable to be stung by curculio and requires the same treatment as plums.

Boston Nectarine-Very large and handsome; deep yellow, with a bright blush, and mottles of red; flesh yellow to the stone; sweet, with a pleasant and peculiar flavor. Freestone.

Early Violet-Medium size; yellowishgreen, nearly covered with dark purplish red; juicy, rich and highly flavored. Last of August.
New White-Large white, nearly round; flesh white, tender, very juicy, with a rich vinous.flavor; stone small, and separates freely. August.

Red Roman-Largest size; greenish-yellow, with a dark, dull, red cheek; flesh yellowish; fine grower and productive. First of September.

\section{APRICOTS}

A delicious fruit of the plum species, valuable for its earliness. It is liable to be attacked by curculio and requires the same treatment as the plum. It bears immense crops, ripening in July and August.

Alexander-Very hardy; an immense bearer; fruit large, yellow, flecked with red; very beautiful, sweet and delicious. July.

Alexis-Very hardy; an abundant bearer. Yellow, with red cheek; large to very large; slightly acid, rich and luscious. July.

Breda-Small; dull orange, marked with red; juicy, rich and vinous. Productive and hardy. First of August.

Catherine-Very hardy, vigorous and productive; medium sized; yellow; mild sub-acid; good.
Early Golden-(Dubois)-Small; pale orange, juicy and sweet. Hardy and productive. First of July.

Gibb-Tree hardy, grows symmetrical, productive; fruit medium, yellowish sub-acid, juicy and rich. Last of June.

Harris-Equal in size and quality to the best cultivated; recommended for its hardiness and good bearing qualities. June 20 th to July 1 st.

J. I. Budd-Tree a strong grower and profuse bearer. Fruit large, white, with red cheek; sweet, juicy, with a sweet kernel, as fine flavored as an a $1 \mathrm{mond}$. The best late variety, and a decided acquisition. August.

Moorpark-One of the largest, orange, with a red cheek; firm, juicy, with a rich flavor; very productive. August.

Nicholas-Tree hardy and prolific; fruit medium to large; white, sweet and melting. A handsome and valuable variety. July.

Peach - Very large ; orange, with a dark cheek; juicy a $\mathrm{nd}$ highlv flavored. 


\section{QUINCES}

The Quince is of late attracting a great deal of attention as a market fruit. Scarcely any fruit will pay better in the orchard. The tree is hardy and compact in growth, requiring but little space; productive; gives regular crops and comes early into bearing. The fruit is much sought after for canning for winter use. When put up in the proportion of about one quart of quinces to four quarts of other fruit it imparts a delicious flavor.

It flourishes in any good garden soil, which should be kept mellow and well enriched. Prune off all the dead and surplus branches, and thin out the fruit if bearing too freely.

Bourgeat-A new, golden. prolific variety, of the best quality; ripening shortly after Orange and keering until midwinter. Tree a remarkably strong grower, surpassing all others.

Champion-Fruit very large, fair and bandsome, surpassing other varieties in this respect; bears abundantly while young; flesh cooks as tender as an apple and without hard spots or cores; flavor delicate, imparting an exquisite quince taste and odor to any fruit with which it is cooked. The most valuable of all.

Meech's Prolific-The most prolific of all known varieties; ripens between the Orarge and Champion. Bears very early, usually a full crop at three years; quality unsurpassed and size large.

Orange-Large, roundish; bright goldenyellow; cooks tender and is of very excellent flavor. Valuable for preserves or flavoring; very productive; the most popular and extensively cultivated of the old varieties. October.

Pineapple-The name comes from the flavor which is suggestive of the pineapple. The fruit in form and in size resembles the Orange Quince, but is smoother and more globular. Makes a superior jelly; possessing a most exquisite and delicious flavor not equalied by any other quince.

Rea's IMammoth-A seedling of the Orange Quince; one-third larger, of the same form and color; fair, handsome; equally as good and said to be as productive. Tree a hardy and healthy grower.

\section{GRAPES}

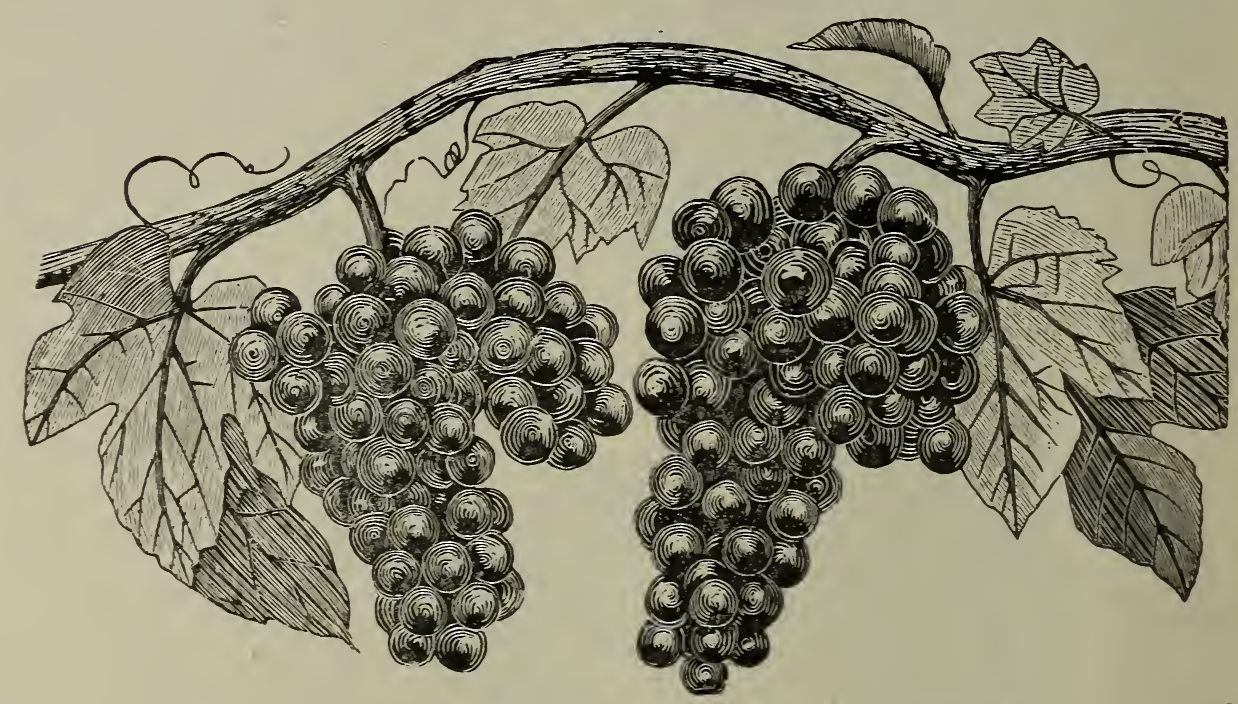

The Grape is the most healthful of all fruits, and the most highly esteemed for its many uses. It can be secured by every one who has a garden, a yard or a wall. It can be confined to a stake, bound to a trellis, trained over an arbor or extended until it covers a large tree or building, and it still yields its graceful bunches and luscious, blooming clusters. Capable of most extraordinary results under wise management, it is prone, also to give the greatest disappointment under bad culture or neglect. Other fruits may be had from plants that know no care, but grapes are only to be had through attention and forethought. We will endeavor to point out a few essential points in its successful culture, and refer the cultivator to other and more extended works for more details. 
Soils-Good grapes are grown on various soils, sandy, clayey, loamy, etc. The soil must be well drained, and there should be a free exposure to the sun and air. Hillsides, unsuitable for other crops, are good.places for grapes.

Crops-Crop grapes moderately if you would have fine, well--ripened fruit. A viue is capable of bringing only a certain amount of fruit to perfection, proportioned to its size and strength; but it usually sets more fruit than it can mature; reduce the crop early in the season to moderate number of good clusters and cut off the small inferior branches; the remainder will be worth more than the whole would have been. A very heavy crop is usually a disastrous one.

Pruning-Annual and careful pruning is essential to the production of good grapes. If the roots are called upon to support too much wood, they cannot bring to maturity a fine crop of fruit. The pruning should be done in November, December, February or March, while the vines are entirely dormant.

Trained Vines-There are many methods of training grape vines, but as trellises are most generally employed, we will confine our suggestions to a description of the trellis method. To construct a trellis take posts of oak, cedar or chestnut 8 to 10 feet long, set them 3 feet in the ground and about 12 feet apart. Stretch No. 9 galvanized wire tightly along the posts and fasten them to each. Let the first wire be 18 inches from the ground and the distance between the wire 12 inches. Wooden slats about one by two inches may be substituted for wires. Trellises should be at least 10 feet apart, a greater distance preferable. Set the vines about 20 feet apart. Prune the vines to two canes for two years after they are planted. In February or March these canes should be cut back to 5 or 6 feet each, and tied along the lower wire or slat of the trellis horizontally.

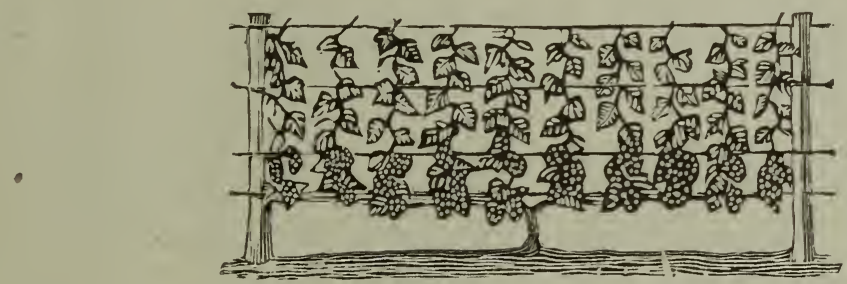

FRUITED GRAPE VINE

When the growth commences in spring the young shoots must be reduced by disbudding so that they may stand about a foot apart on the cane, selecting of course strong healthy shoots; as they grow they are tied up to a second, third and fourth wire or slat, and all other superfluous ones removed, as well as the young laterals, which will appear on vigorous vines; but the first fruit-bearing shoots are allowed to extend themselves at will until September, when they may be pinched off at the end to assist the ripening of the wood. The vine in autumn, with the fruit on, will present the appearance of the above cut and before pruning in the autumn, after the leaves are off the following appearance. The next pruning, which may be done in November or December, if it is desirable to lay the vines down and cover them over for the winter; or in February or March if not laid down, consists in cutting back all young wood of the previous year's growth (except such shoots as may be required to extend the horizontal arms), to within one or two good buds of the bearing canes on the lower wire, giving the vine the appearance of the following cut:

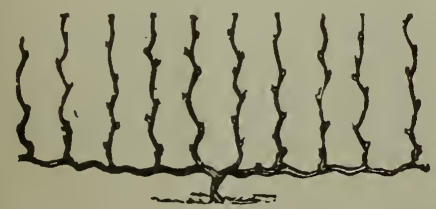

BEARING VINE BEFORE PRUNING

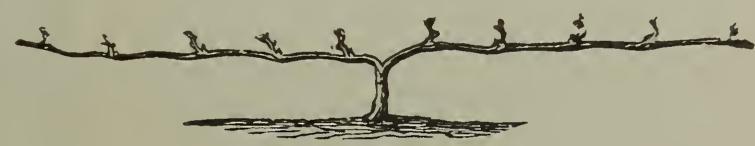

PRUNED TINE

Each season thereafter the vines are to be treated in the same manner, cutting back every year to the lower wire or slat, extending the vine only in a horizontal direction, thinning vines in the rows by digging up every other plant, if necessary, but never growing any grape above the second wire, and renewing the bearing canes by new shoots from the stumps when required. 
Gathering and Keeping-Grapes for keeping, to be used in their fresh state, should be allowed to remain upon the vines until perfectly matured, but not much longer. Pick them when perfectly dry. Let them stand in open baskets or boxes for about ten days in a cool dry room, and after sorting out all decayed and imperfect berries, pack them in shallow boxes and cover closely. Use no paper, but basswood or elm boxes, if convenient. Pine and other resinous woods should not be used, as they flavor the fruit disagreeably. After packing, keep the boxes where it is both cool and dry. Under careful management some varieties may be kept until spring.

\section{CLASS I-BLACK GRAPES}

Barry-(Rogers' No. 43)-Bunch large, but rather short; berries large, roundish, much like Black Hamburg; delicate, sweet and tender. Ripens with Concord. Vine vigorous and productive. One of the largest and finest of the Rogers' Hybrids.

Campbell's Early-This is not a chance seedling, but the result of carefully conducted experiments by the orig. inator through successive crossings of the most promising varieties which he had produced or tested within the past thirty years.

Champion-A large grape of medium quality; a strong grower and very hardy; the earliest of all; succeeds in all sections, and this makes it one of the most valuable market grapes.

Clinton-Bunches small and very compact; berries small and sprightly. When thoroughly ripe is a good table grape and keeps well.

Columbian-Very strong grower, with thick, leathery leaves. Regarded with high favor on account of its large size, showiness and early ripening. Ripens with Moore's Early.

Concord-A large, handsome grape, ripening a week or two later than Isabella; very hardy and productive. Succeeds over a great extent of country, and, although not of the highest quality, it is one of the most popular market grapes.

Eaton-Black; bunch and berry of the very largest size; not quite so early nor sweet as its parent, the Concord, but less foxy; pleasant and juicy, with tender pulp. Vine very vigorous, healthy and productive. Originated in Massachusetts.

Early Ohio-The earliest black grape known; ripens ten days to two weeks before Moore's Early. Bunch large, compact and shouldered; berry medium, covered with heavy bloom; as hardy or more so than the Concord. A vigorous grower, very productive and of good quality. Berry adheres firmly to the stem. One of the best shippers. The only early grape that will not shell.

Hartford Prolific-Bunches rather large; berries large, globular; color almost black covered with a beautiful bloom; of a fair quality, ripens three weeks before the Isabella; valuable for its abundant bearing and early maturity.

Isabella-An old standard sort, highly prized where it will thoroughly mature. Bunches long, large, loose; berries large, oval, sweet and musky; a good keeper.

Merrimac-(Rogers' No. 19)-B u n c h medium to large; berry large, sweet and rich; vigorous and productive; one of the earliest and best of the Rogers' sort.

Mills-Black. Originated in Canada. Vine vigorous, hardy and healthy; supposed to be a cross between a native and foreign variety; bunch very large, long and shouldered; berry medium to large; adheres firmly to the stem; flesh firm, meaty, rich and sprightly.

McPike-Originated by H. G. McPIKE, of Mount Lookout Park, Alton, Illinois. A seedling of Worden, with all its good qualities, unequaled leaf, perfect character in every point, superb quality, color and flavor like the Worden; berries very large, measuring over three inches in circumference; easily the best grape grown.

Moore's Early-Bunch large; berry round (as large as the Wilder or Rogers' No. 4 ); color black, with a heavy blue bloom; quality better than Concord; vine exceedingly hardy; has never been covered in the winter, and has been exposed to a temperature of more than twenty degrees below zero without injury to it; has been entirely exempt from mildew or disease. Its earliness makes it desirable for an early crop, and more particularly adapts it to New England and the northern portion of the United States, maturing as it does, ten days before the Hartford and twenty before the Concord.

Wilder-(Rogers' No. 4)-Large and black; bunches generally shouldered; berry round and large; flesh buttery, with a somewhat fibrous center; sweet, rather sprightly; ten days earlier than the Isabella.

Worden-This new variety is a seedling of the Concord, which it greatly resembles in appearance and flavor, but the berries are larger. The fruit is said to be better flarored and to ripen several days earlier. 


\section{CLASS II-RED AND PURPLISH GRAPES}

Alice-A red grape, of very vigorous growth and hardiness; in quality fully equal to Delaware by actual test. Ripening with or before Concord and keeping in perfect condition, without cold storage throughout the winter. It does not shell and under suitable conditions will raisin instead of rot. Vine very productive.

Agawam-(Rogers' No. 15)-L a r g e, round, early and of great vigor of growth. Rich, peculiar aromatic flavor. Considered by Mr. Rogers as the best of his strictly red hybrids. September.

Amber Queen-A new and promising variety which originated in Massachusetts. Bunch and berry of medium size; color light amber; flesh tender to the center; juicy, sprightly and delicious. Larger than and as early as Delaware.

Brighton - A cross between Concord and Diana Hamburg. Flesh rich, sweet and of the best quality. Ripens earlier than Delaware. Vine vigorous and very hardy. This variety has now been thoroughly tested, and without an equal among early grapes.

Catawba-Well-known as the great wine grape of Ohio. Kentucky, etc. Bunches large and loose; berries large, of a (cop)pery-red color, becoming purplish when well ripened, two weeks later than Isabella; requires the most favorable soils and situations, good culture and warm seasons to mature in $\mathrm{Vestern}$ New Tork.

Delaware-Still holds its own as one of the finest grapes; bunches small, compact, shouldered; berries rather small, round; skin thin, light red; flesh very juicy; without any hard pulp, with an exceedingly sweet, spicy and delicious flavor. Vine moderately vigorous, hardy and productive. Ripens two weeks before the Isabella.

Goethe-(Rogers' No. 1)-Vine vigorous, productive; flesh tender to the center, juicy, sweet pleasant, slightly aromatic. A good grape.
Jefferson-Vine very vigorous, extremely hardy; bunch very large, often double shouldered, compact; berries large, roundish oval; light red, with a thin lilac bloom; combines the sugary richness of the Brighton, the tender meaty flesh of the Iona, with just enough vinous flavor to make the fruit deliciously sprightly and unsurpassed. Ripens with Concord.

Lutie-It is the earliest in market; never known to rot; vine perfectly hardy, a strong grower and enormously productive. Vines two years old from cuttings have produced each twenty-fire pounds of choice fruit. Flavor equal to Delaware, sweet and rich.

Lindley-(Rogers' No. 9)-Bunch long and compact; flesh sweet; ripens soon after Delaware. One of the best and earliest of the Rogers'.

Moyer-A new grape originated in Canada. In habit of growth and hardiness it resembles the Delaware very much but ripens earlier. Flavor sweet, delicious; skin tough but thin; pulp tender and juicy.

Perkins-Vine vigorous and productive; bunch compact and shouldered; ripens before Isabella.

Salem-(Rogers' No. 22)-This is regarled as the best of Mr. Rogers' hybrids. Bunch large; berry large, round; flesh tender, juicy, with a rich, aromatic flavor; slight pulp; a good keeper.

Vergennes-Originated at Vergennes, Vt near Lake Champlain. The originator says of it: "Clusters large; berries large; color light amber; flavor rich and delicious, ripening here fully as early as Hartford Prolific.', Its keeping qualities are superior.

Woodruff Red-This very large and handsome red grape is a seedling of Concord. Vine a very strong grower; free from disease and very hardy; bunch large, shouldered, berry very large and does not drop from the stem.

\section{CLASS III-WHITE GRAPES}

Duchess-Bunch large (often eight inches long) shouldered, compact; berries medium size, greenish white; flesh tender, without pulp; flavor sprightly, rich and delicious. Ripens about with Concord. Vine a strong grower and very hardy.

Empire State-A purely native variety; remarkable strong grower; foliage resists mildew; extremely hardr, very productive; fruit ripens early, of best quality; hangs firmly to the stem; continues a long time on vine; remarkably good keeper.
Green Mountain-A very early and delicious grape; pulp tender and sweet, with but one or two seeds; bears young and profusely, and ripens from the $25 \mathrm{th}$ of August to the 1st of September. The only grape thus far tested that ranks first, both in earliness and quality.

Lady-Originated in Ohio. A seedling from Concord. Bunch and berry medium size, light greenish-yellow, covered with white bloom; flesh tender and sweet, lacking character. Vine hardy and productive. 


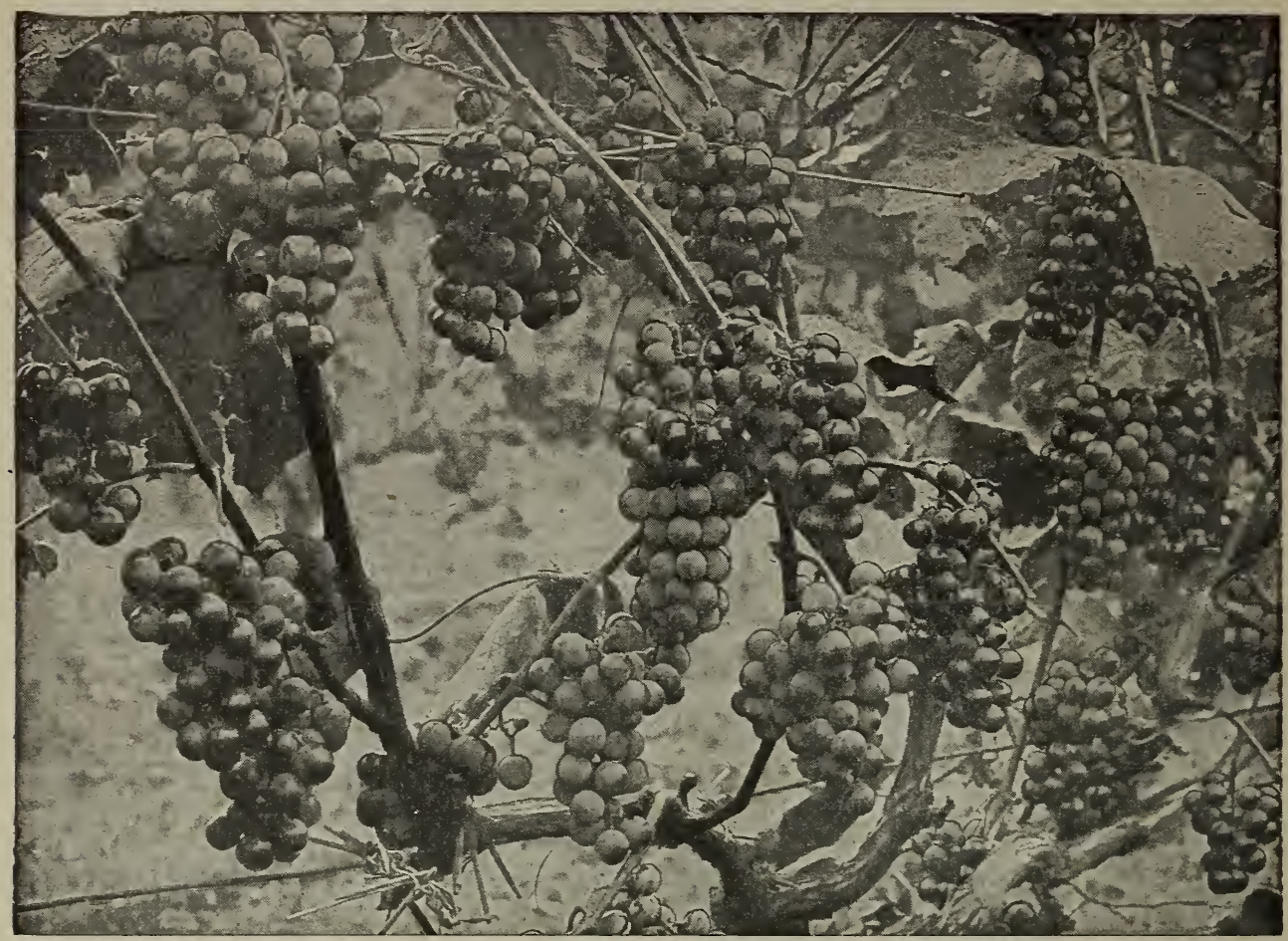

NIAGARA

Lady Washington-Vine very vigorous; berry medium to large, round; color deep yellow, with a tinge of delicate pink where exposed to the sun, and covered with thin, white bloom.

Martha-Native of Missouri. Bunches medium, shouldered; berry large, roundish; flesh similar to Concord; a little foxy, but very good; ripens earlier than Concord. Vine vigorous and hardy. Deservedly popular.

McKinley-A large EARIY WHITE GRAPE, as large as the Niagara and productive; strong grower, and robust foliage. It is a cross between Niagara and Moore's Early. It was originated near where the Niagara Grape originated. It is fully ten days earlier side by side. Bunches very large and compact, very sweet with no acid around the seeds and no puckery taste in the skin. It is the coming Early Grape for market.

Moore's Diamond-A vigorous grower, with dark healthy foliage; entirely free from mildew. A prolific bearer; bunches large, handsome and compact, slightly shouldered; color delicate greenish-white, with rich yellow tinge when fully ripe. Skin smooth and free from specks; pulp tender, juicy and nearly transparent, with very few seeds; berry about the size of Concord. Quality best; rich, sprightly and sweet. Ripens about two weeks before Concord.
Niagara-This white grape is justly regarded as one of the very best known; very fine quality for a table grape; very prolific, hardy and fine grower.

Pockington-Is a seedling from Concord; fruit a light golden-yellow, clear, juicy and sweet to the center, with little or no pulp bunches very large, sometimes shouldered; berries round, very large and thickly set. First of September.

Prentiss-A pure native seedling. Vine vigorous and hardy; clusters of a good size, compact; berries medium to large; flesh tender, sweet, with a pleasant aromatic flavor. Very productive, inclined to overbear. Ripens about with Concord.

Rebecca-A fine and delicious white grape; berry and bunch medium size. Vine a free, slender grower and abun. dant bearer; not quite hardy. Ripens almost as soon as the Delaware. We regard it as one of the highest flavored of our native grapes; recommended particularly for careful garden culture.

Rommel-Large, greenish-yellow, tender, melting, of fine quality; vigorous and hardy. 


\section{STRAWBERRIES}

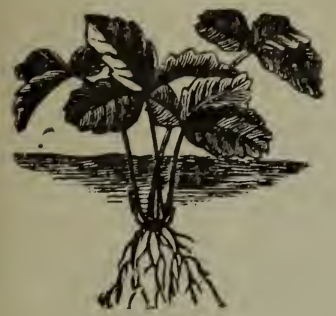

FIG. 1

Planted too Deep

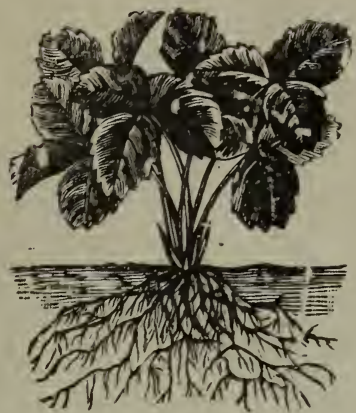

FIG. 2

Right way of Planting

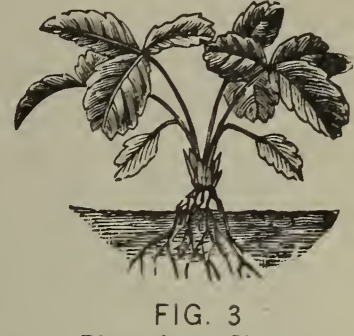

Planted too Shallow

Strawberries may be successfully grown on any soil adapted for garden purposes, or where good crops of grain or potatoes can be raised. The ground should be well prepared, thoroughly enriched, and should be kept free from weeds.

In the Middle and Northern States the plants should be set during the months of April and May. Pot plants that will produce some berries in the season following the planting may be set in August or September, but these are necessarily expensive. Plants taken from the open ground in August or September are much more liable to injury in transit than those sent in the spring, and need careful shading and watering until established.

Three hundred bushels per acre is not an unusual crop. In our lists we indicate pistilate sorts with the letter $\mathrm{P}$.

Bederwood-Fruit large, conical, bright red and of excellent quality. All things considered, this is one of the very best early varieties. Plant a good healthy grower.

Brandywine-A new variety of Pennsylvania origin, very highly recommended; of immense size and fine quality; firm and shapely; large berry. Medium to late.

Bubach's No. 5-Very prolific, of excellent flavor, sweet sub-acid, and in size simply immense-berries averaging large-many over $2 \frac{1}{2}$ inches in diameter and 7 inches in circumference. Its equal has not been produced on this continent.

Charles Downing-A general favorite, succeeding everywhere under all systems of culture. Medium to large; bright crimson; handsome; moderately firm and of superior quality. One of the best for home use.

Clyde-The Clyde is considered one of the best Strawberries of recent introduction. Ripens early; as large as Bubach, or larger; better quality and much finer. The plant is strong and healthy; foliage light green.

Crescent Seedling-(P)-Large, averaging larger than Wilson's Albany; conical; color a handsome bright scarlet; quality very good. In productiveness unequalled, having produced over 400 bushels per acre. Plants very strong and vigorous. A most valuable market sort.
Gandy-A very strong growing plant; moderately productive; fruit large, uniform shape, bright color, and good quality; season late. A cross between Jersey Queen and Glendale. Ripening two weeks after the Sharpless.

Glen Mary-(P)-A new variety especially recommended for vigor and productiveness of plants, size and beauty of berries and of excellence of flavor. Medium to late.

Greenville-It leads for productiveness, market, home use, and general purposes; combines earliness, firmness, large size, good quality; very even and fine color, with wonderful vigor and health of plant; free from rust, and attains its greatest productiveness when planted near Bederwood.

Haverland-(P)-Large, healthy, vigorous growing plant; very productive; fruit large, conical, with slight neck; uniform in size and shape; bright red; firm.

Jessie-Plant a strong, robust grower, similar to Sharpless. On most soils it is a robust, healthy plant; long, stout fruit stalks hold the fruit well up from the ground. Berries of the larger size; medium to dark red color all the way through; firm and solid and of the most excellent quality; very few small berries and none of the larger ones of irregular shape. 


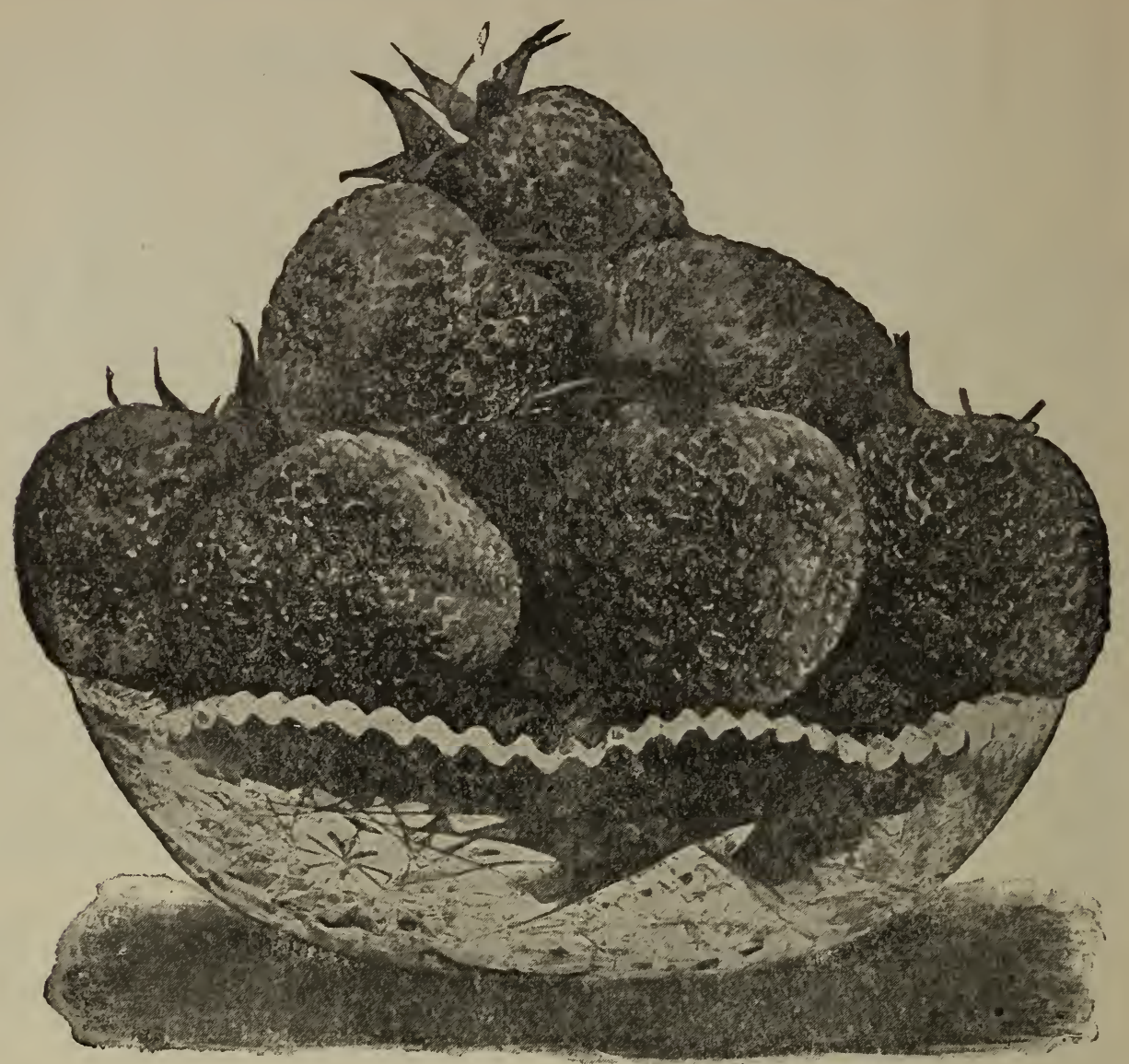

GANDY

Marshall-Season late. Beries deep blood red to center, flavor very much like the wild berry. Foliage large and vigorous. While it will not perhaps yield as many quarts to the acre as some medium sized berries, yet it is the best extra large berry. It makes comparatively few runners in hills to get largest berries.

McKinley-Well tested and proved to be a superb variety in every respect. Flesh firm, quality excellent. Plant vigorous, healthy and a wonderful yielder.

New Home-This berry is certain: , very fine; a vigorous and thrifty srower; the berries large and even in ore; an abundant producer. Should ve planted by all berry growers, either for market or home use.

Parker Earle-A splendid berry; uniformly large, regular, conical with a short neck; color glossy scarlet-crimson; ripens all over; flesh moderately firm, no hollow core; quality good; flowers perfect; always setting perfect fruit. Plant very vigorous, healthy and remarkably productive.
Senator Dunlap-This berry is one of the best. Very productive, plants very strong and thrifty, producing immense quantities of large, fine, juicy fruit, which always sells at top market prices.

Sample-A new variety that has been tested and found satisfactory in every respect.

Sharpless-Very large; average specimen under good cultivation measuring $11 / 2$ inches in diameter; generally oblong, narrowing to the apex, irregular, often flattening; clear light red, with a smooth, shining surface; firm, sweet, with a delicious aroma. Vigorous, hardy and very productive when raised in the hills with runners cut off.

Shuckless-This is the most remarkable strawberry ever introduced. In picking it parts readily from the stem, the shucks remaining on the stem instead of the berry, which makes it of great practical value for table use. Plant a strong grower, hardy, and a late bloomer; produces berries of uniform size and color. 
Timbrell-The vine is a thrifty grower, with rank, dark foliage, after the nature of Parker Earle, and the berry is large, symmetrical, dark crimson color, which runs through the flesh. It is a good yielder of large, handsome berries, so firm they will stand long shipments in good condition. Ripens late.

Van Deman-Very early; an immense cropper; good canner. Quality will rank with the best.

Warfield No. 2-Berry dark red, conical in shape; flavor much like Wilson when ripe; sweet and rich; a vigorous grower, with long, penetrating roots to resist the drought; tall leaves to protect the blossom from frost.

Wilson's Albany-Medium to large; dark red; very hardy, vigorous and productive. The most widely known and universally successful strawberry.

Wm. Relt-A splendid new sort and worthy of a trial.

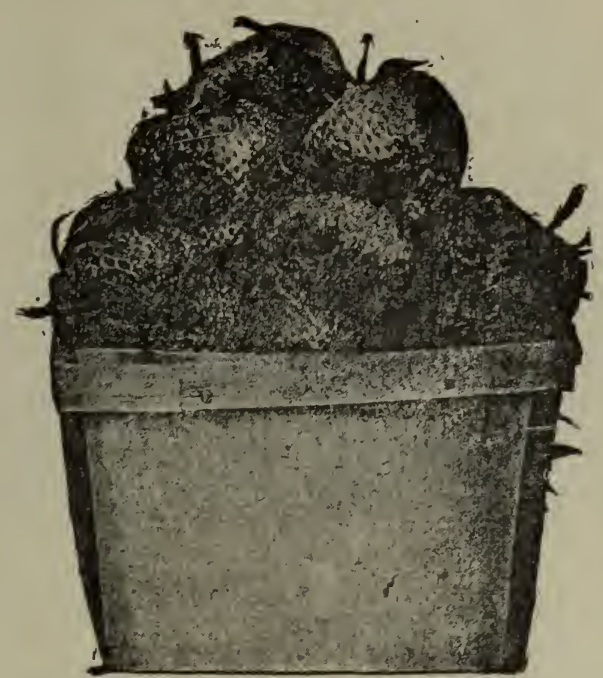

JESSIE

\section{RASPBERRIES}

Coming immediately after Strawberries, when there is a dearth of other fresh fruit, Raspberries are equally desirable for planting in the garden for home use and in the field for market. They are easily cultivated. Beds seldom require renewing. Their season of ripening is long. The fruit bears transportation well, and aside from its demand for immediate consumption, it brings highly remunerative prices for drying and canning.

Plant in good soil and manure from time to time freely. The hills should be not less than four feet apart each way, with two of the plants on a hill. Cut out the old and weak shoots each year, preserving not over six for fruiting. If the location is much exposed and the plants inclined to kill down seriously, they may be bent over in the fall on mounds of earth formed at one side of the hills and covered sufficiently to keep them down until spring. Surplus suckers take strength from the bearing plants. They should be cut away or hoed up frequently.

Raspberries may be made very profitable with good cultivation.

\section{CLASS I-RED AND YELLOW VARIETIES}

Brandywine-(Susqueco)-Large; bright red; very firm. Valuable for market on account of its fine shipping qualities.

Cardinal-A surprise in the fullness of its merits-its great growth, extreme

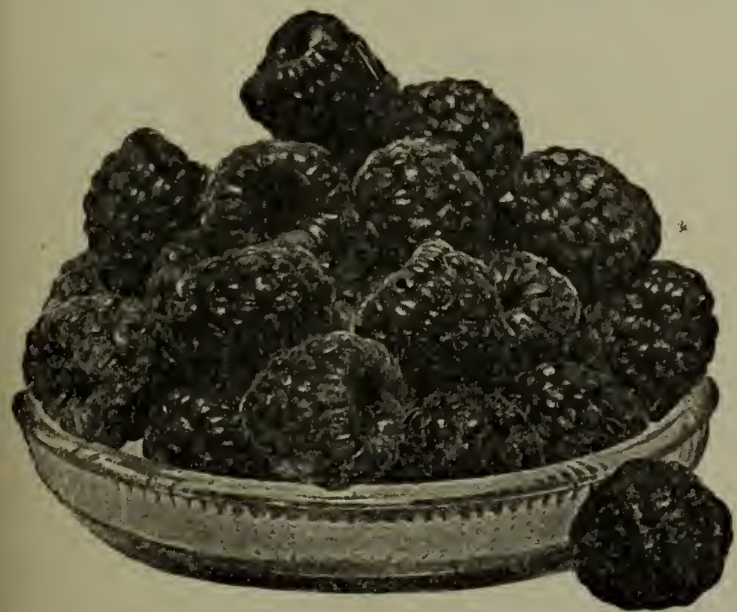

COLUMBIAN hardiness, and the exceeding productiveness of its choice red, rich, pureflavored berries. It thrives where others fail; it will pay; it is not a novelty, but a variety of great merit.

Caroline-A s e ed ling. from Brinkle's Orange, combining the peculiar melting and luscious flavor of that variety with canes of great vigor, entire hardiness and extreme productiveness. Color pale salmon; berries large and of fine quality.

Columbian-The greatest Raspberry of the age. It is a seedling of the Cuthbert, grown near the Gregg, and is believed to be a cross between the two. It is enormously productive; of large size and excellent quality. Season of fruiting from July 12 th to August 15th. It has stood 28 degrees below zero without injury; is propagated from the tips, and does not 
sucker. The color is dark red; adheres to the stem; does not crumble in picking, and is a splendid shipper. It has yielded over eight thousand quarts per acre.

Cuthbert-(The Queen of the Market)Large, conical; deep rich crimson; firm, of excellent quality. A vigorous grower, entirely hardy and immensely productive. "I regard it as the best raspberry for general culture." Charles Downing.

Golden Queen-This variety is a seedling of the Cuthbert, but the color of the fruit is a rich golden-yellow. The flavor is of the highest quality; in size equal to Cuthbert. Immensely productive; a very strong grower and hardy enough for entire northern latitudes, having stood uninjured even when the Cuthbert suffered.

Haymaker-The most vigorous grower of all raspberries. Very hardy. Fruit very large, conical; color bright red, and very attractive; flavor superb; delicious for table use and splendid for canning. It is a prodigious bearer, of long season; fruit of fine texture; does not drop from the bush. A superb shipper.

Hansell-Medium to large, color bright crimson; flesh firm, quality best. Canes vigorous, entirely hardy, and very productive. Very early.

Herbert-A Canadian seedling. Has been tested at N. Y. Exp. Station and by many large growers, all giving it very favorable reports. In hardiness, it easily takes first place. The cane is very strong and vigorous, leaves large and healthy, and has never been affected by Anthracnose, or disease of any kind. Fruit bright red, somewhat oblong, the largest of all red raspberries. Flavor, very sweet and juicy, the very best for table use. Enormously productive will bear twice the crop of either Cuthbert or Loudon, under the same conditions. Season, 5 to 6 days before Cuthbert. Holds its size well to the end of season.

Japanese Wineberry-Strong grower and handsome; somewhat smaller than the red raspberries; sparkling and attractive, flavor rich, rather acid; excellent for jelly. Deep amber.

King-Large, crimson; firm; flavor very good; hardy. A new variety. An abundant and early bearer.

Loudon-Ripens with the earliest and hangs to the last. In productiveness it is beyond any red raspberry known, and is a famous shipping berry. It is as hardy as the Turner and is of superior quality.

Marlboro-The best early red raspberry for the North, ripening soon after the Hansell. Hardy and productive.

Miller's Red-Vigorous and sturdy in cane; very early. Fruit large and profuse; beautiful and brilliant in color; sweet, luscious flavor. Nothing in the way of red raspbrries since the advent of the Cuthbert can be compared with the Miller in point of value.

Philadelphia-An old market sort of moderate size and fair quality; very hardy and productive. Still grown largely in some placs.

Reliance-A seedling from Philadelphis, but much more valuable. Flesh firm, quality good; canes hardy and productive. A valuable sort.

Royal Church-Berry large, dark crimson, hardy, firm and of good quality. Flavor exceedingly delicious, aromatic and sprightly. Berries do not crumble in picking, and have very few seeds.

Superlative-Large, conical, handsome; dull red; six good berries weigh an ounce; flavor very fine, par excellence; a dessert kind. Canes stout, supporting themselves; a very heavy cropper. Hardy.

\section{CLASS II-BLACK CAPS}

Cumberland-This new berry is a very valuable acquisition, with its greatly superior size it combines the equally valuable characteristics of great firmness, splendid quality and wonderfu] productiveness. The plants are entirely hardy, very vigorous and healthy, and seem entirely unaffected by either Anthracnose or "yellow blight." In season of ripening it follows Palmer and Souhegan, and precedes Gregg a short time, making it a mid-season variety.

Earhart-Strong, stocky grower, with an abundance of stout, heavy spines; very hardy; fruit of large size, jet black and good quality, commencing to ripen early and continues till frost.
Gault Perpetual-Fruit immense size; commences to ripen with Gregg, continuing two or three weeks longer, when fruit on young canes commence to ripen, continuing till frost. Young canes frequently produce clusters of 80 to 100 perfect berries.

Gregg-Of good size, fine quality, very productive and hardy. It takes the same position among black caps as Cuthbert among the red sorts. No one can afford to be without it.

Johnston's Sweet-Smaller than the Gregg, of same color. A good strong grower, healthy and hardy, ripening with Tyler; stands up well in picking and handling. 


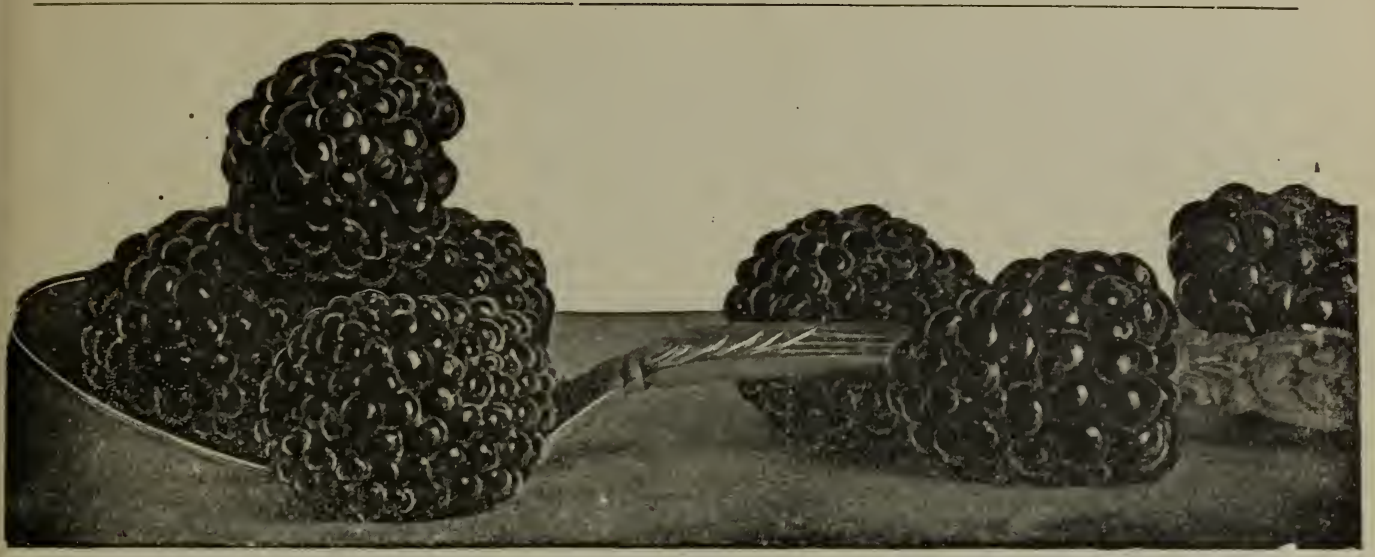

CUMBERLAND

Kansas-Canes are of strong growth, very hardy and prolific, with tough, healthy, clean foliage. Its season second early, ripening after Souhegan, but much earlier than Gregg. It is beyond question, a variety of great value. Mammoth Cluster-The largest black cap except Gregg. Canes of strong growth and very prolific. Berries large and of fine quality.

Munger-Excels all others in size and productiveness -5 to 8 days later than Gregg.
Ohio-A very strong growing hardy sort; fruit nearly as large as Mammoth Cluster; more productive than any other variety, and one of the most if not the most valuable for market.

Souhegan-A new variety commended very highly as a market sort by those who have grown it. Said to be enormously productive, perfectly hardy and free from disease of any kind.

\section{GOOSEBERRIES}

This fruit is useful for cooking, when green or ripe, and it may be canned with such facility that it is beginning to be cultivated very extensively for both home use and market.

It requires the same cultivation and treatment for worms as the currant. The worms attack the Gooseberry before the currant bushes, and if a few of the former are set near a currant plantation, and the worms exterminated on these, there will be little if any trouble from them on the currant bushes.

The American varieties, though not quite so large as the English sorts, are of fine quality and are not subject to mildew.

Champion-A new variety introduced from Oregon, where it originated; fruit large, round; an immense bearer, and entirely free from mildew. One of the best yet introduced.

Chautauqua-A new strong growing variety of the English type. Very promising. Fruit white, of the largest size and enormously productive. Its size, beauty, productiveness and good quality will make it very popular with intelligent and energetic fruit growers.

Columbus-A new American seedling. Gooseberry of the English type. It is of large size, oval in form, skin greenish-yellow, smooth, of fine quality. Plant a strong, robust grower, with large spikes of thorns. Foliage large and glossy. Has never shown a trace of mildew. We confidently recommend it as one of the best of its class.

Downing-Originated at Newburgh, $N$. $Y$. Fruit much larger than Houghton; roundish, light green, with distinct veins; skin smooth; flesh soft, juicy and very fine flavored. Vigorous and productive. The most valuable American sort.

Golden Prolific-A remarkably strong, vigorous and upright grower, with dark-green glaucous foliage, which resists mildew perfectly, and persistently hangs on until the end of the season. The fruit is of the largest size, oblong, good, sample measuring $13 / 4$ inches in length. Color golden-yellow; flavor decidedly good; very productive. 
Houghton's Seedling-A vigorous American sort, very productive, free from mildew. Fruit medium, roundish, smooth of a pale red color; tender, sweet and of a delicious flavor.

Industry-This is said to be the best English Gooseberry yet introduced. It is of vigorous, upright growth, a great cropper. The berries are of the largest size, dark red, hairy, rich and agreeable, of fine quality and excellent flavor. New and very desirable, as it is the largest grown. Size $1 \frac{1}{4}$ to $21 / 2$ inches.
Pearl-Originated by Prof. William Saunders, of the Experimental Station, Ottawa, Canada. It has also been thoroughy tested at nearly all the experimental Stations in the United States and reports are unanimous in its favor. It is a wonderful cropper, strong grow. er and free from mildew. Fruit third larger than Downing.

Red Jacket-(Josselyn) - This new American Gooseberry is as large as the largest English variety. Berry smooth; very prolific and hardy; quality and foliage the best.

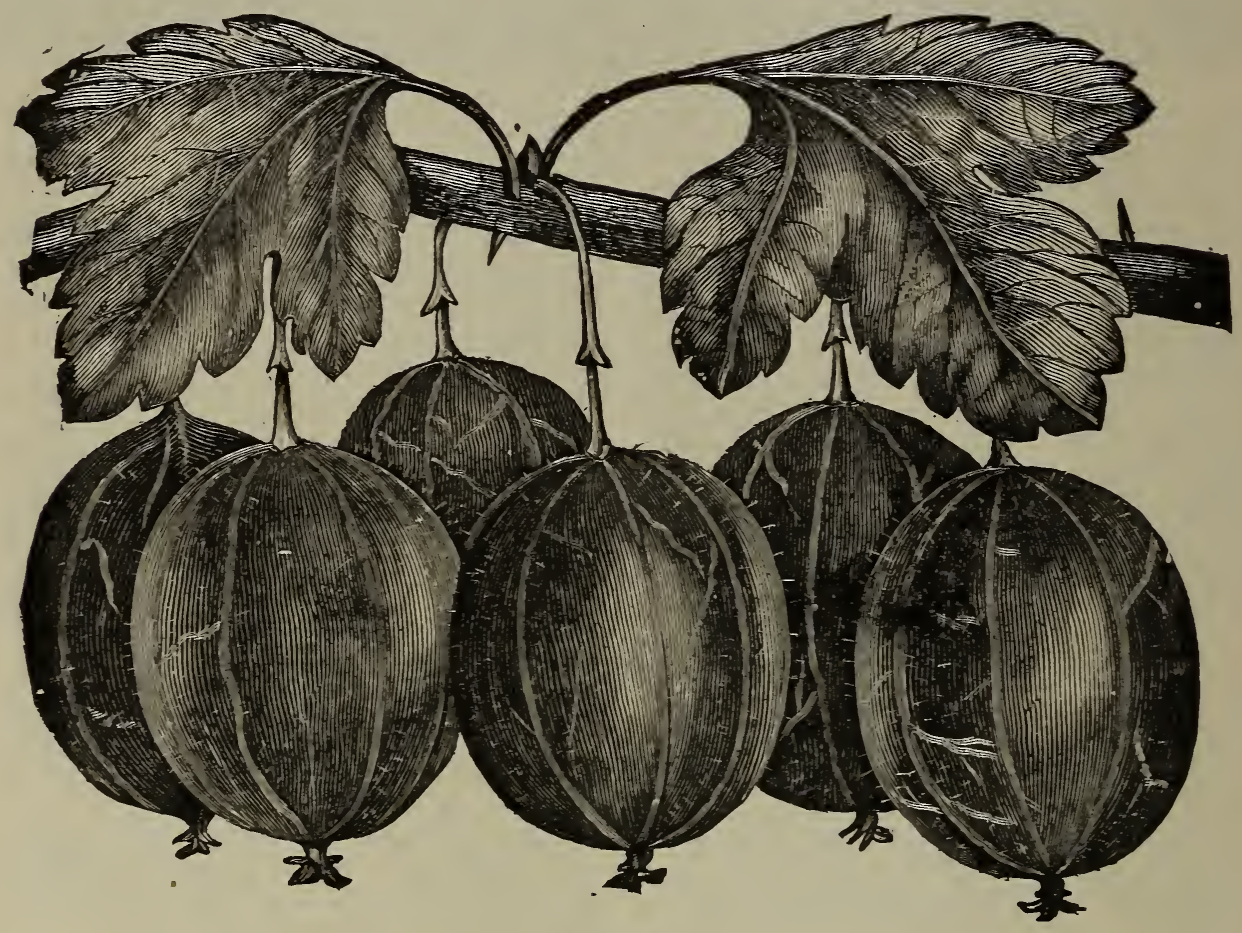

VICTORIA

Keepsake-Color white or light yellow. Quality as good or better than the Industry and more productive than that variety.

Mountain Seedling-From Lebanon, N. Y. Very large, oval, brownish red, with long stalk; skin smooth, thick; flesh sweet; strong, but a rather straggling grower.
Smith's Improved-From Vermont. Large oval, light green, with bloom; flesh moderately firm, sweet and good. Vig. orous grower.

Victoria-This new gooseberry is a wonder. It is the strongest grower the greatest cropper, and finest flavored of Red Gooseberries. It is superior to Industry in its growth, yielding larger crops of its delicious high flavored fruit, which is superb in quality-and ripens ahead of Industry. We bespeak for its great success.

\section{CURRANTS}

Ripe just before Raspberries are gone, continuing in prime order for several weeks, there is no more useful fruit than the currant, and is among the easiest to cultivate.

Plant in rows four feet apart each way, if practicable. Light and air will do as much to enhance the value of currant bushes as with other plants. Keep the ground 
mellow, free from weeds, and in a good state of fertility, and prune freely every spring. Should the currant worm appear, dust a little white hellebore powder from a small, coarse bag, over the bushes when the leaves are damp. In some instances it may be necessary to repeat this process, but the trouble and expense of exterminating the worms is trifling; if the powder is applied as soon as the worms appear.

Black Champion-Bushes large, and flavor of fruit particularly delicious. It haugs long on the bunches, and un. like other varieties, bears the severest pruning without detriment.

Black Naples-Very large; black, rich, tender, and excellent for jellies and wines; very productive.

Cherry-Very large, deep red, rather acid; bunches short. Planits erect, stout, vigorous and productive.

Crandall - Perfectly h a r d y, very strong grower; adapted to all soils, a profitable market variety, as it keeps a long time after being picked; very large, averaging three times as large as huckleberries; sells at highest prices.'

Fay's Prolific-Originated in Chautauqua County, N. Y.

A cross between Cherry and Victoria of large size, fine flavor and claimed to be five times as prolific as the Cherry. A great acquisition.

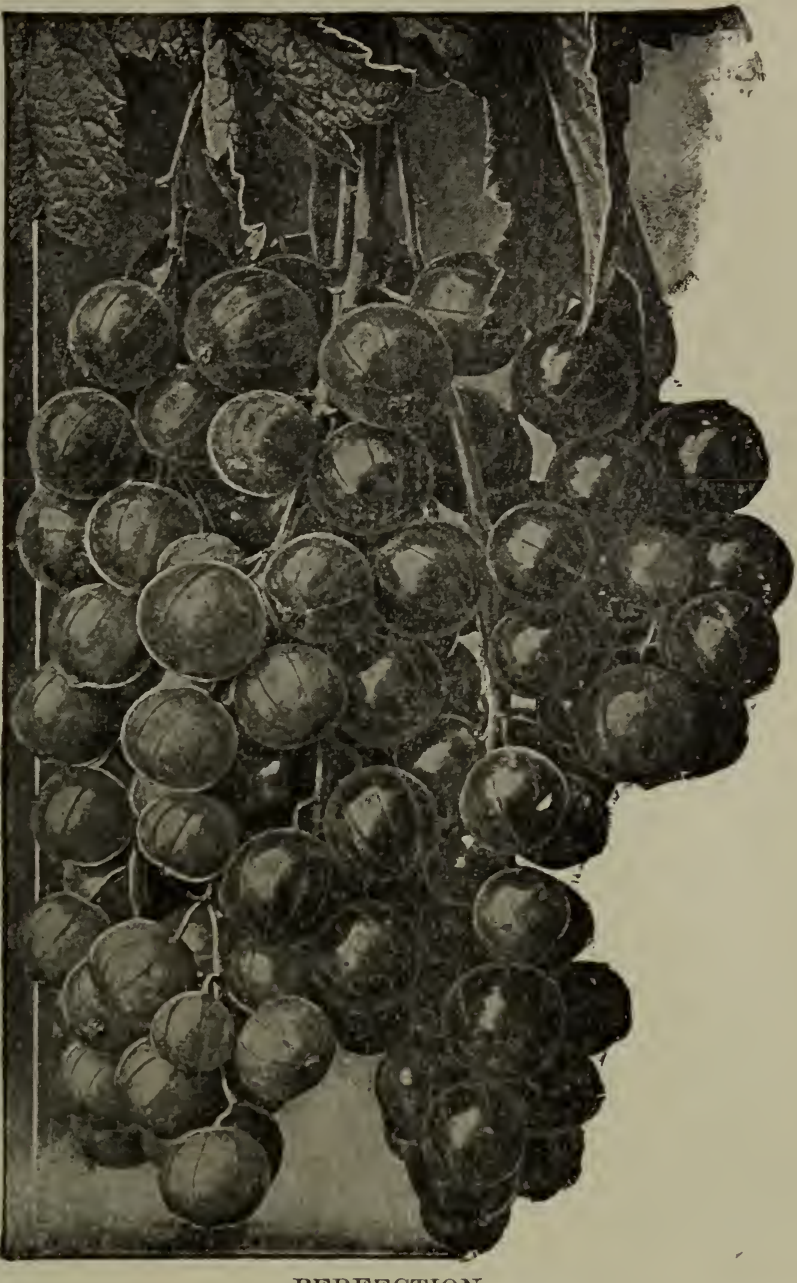

PERFECTION

rich, mild, sub-acid flavor, with plenty of pulp and few seeds, clusters are long and size of berry is maintained to the end.

La Versailles-Very large, red; bunch long, of great beauty and excellent quality; one of the finest and best and should be in every collection. Very productive.

Lee's Prolific Black-A new English variety. The fruit is large and of superior quality; the bush is a rigorous grower and enormously productive, rendering it very profitable.

North Star-It is claimed for this variety that it is the best growing, the best flavored, and the most prolific red currant.

Pomona-A new red currant. One of the best.

Perfection-Berries are of a beautiful bright red and larger than Fay's Prolific. In quality it is said to be superior to anything in the market today;

Red Cross-A new red currant of large size and superior quality; exceedingly vigorous and productive, with long fruit stems.

Red Dutch-An old well known standard variety; berries dark red, sub-acid, sprightly flavor; clusters medium to large.

Victoria-A splendid variety, ripening two or three weeks later than the others and continuing in fine condition for a long period. Bunches extremely long; berries of medium size, brilliant red and of the highest quality.

White Imperial-New and of great value; fruit larger and stems longer than White Grape; enormously productive; quality mild, delicious, sub-acid. 
White Grape-Very large, yellowishwhite, sweet or very mild acid; excellent quality and valuable for the table. The finest of the white sorts. Very distinct from White Dutch, having a low spreading habit, and dark-green foliage. Very productive.
Wilder-Very large, light red, unequaled for table, canning or market; enormously productive; flavor delicious, mild acid.

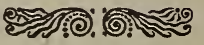

\section{BLACKBERRIES}

This excellent and profitable fruit should be planted for garden use in rows six feet apart, with plants four feet apart in the rows; for market, in rows eight feet apart, with plants three feet apart in the rows. Give the plants the same cultivation as Raspberries.

Agawam-Ripens earlier than other kinds, and has a flavor similar and equal to the wild berry. Perfectly hardy.

Ancient Briton-A new and valuable blackberry. Perfectly hardy and very productive. It ripens early and continues in fruiting a long time.

Blower-Originated in the celebrated small fruit belt of Chautauqua County, N. Y., where it has been thoroughly tested for several seasons. Claimed to be the hardiest, most productive, the finest quality and to bring on the market the highest price of all blackberries. Has produced 2694 berries on one bush, 2720 quarts on $1-3$ acre. Large size, jet black, good shipper, best quality, unexcelled productiveness are the main characteristics of this splendid new sort.

Early Harvest-One of the earliest, berry medium sized, good quality and very prolific; firm and attractive in appearance. A good market sort.

Eldorado-Vine is vigorous and hardy; berries are very large, black, borne in clusters; ripens well together; sweet, melting and pleasing to the taste.

Erie-Very large and very hardy. A strong grower and great bearer, producing larger, sweeter berries, earlier in ripening, than any other sort.

Iceberg-This remarkable berry was originated by Luther Burbank. The fruit is not only white but so transparent that the seeds, which are unusually small, can be seen in the ripe berries. The clusters are larger, and the berries sweeter and more tender and melting than those of the Lawton, its parent. Is quite up to the average in hardiness and productiveness. A great novelty.

Kittatinny-Large, black sweet, soft when black. Very hardy; ripens up gradually like the Lawton. One of the best, except in Northern sections.

Lawton-(New Rochelle)-The wellknown market variety.

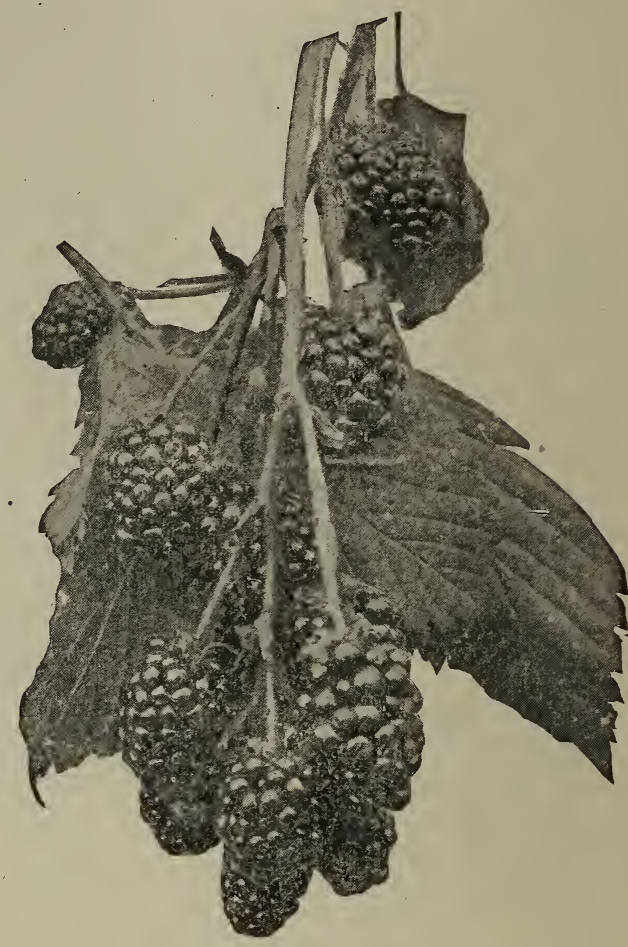

ERIE

Lucretia-(Dewberry)-One of the lowgrowing, trailing blackberries; in size and quality it equals any of the tallgrowing sorts. Perfectly hardy, healthy and remarkably productive, with large, showy flowers. The fruit, which ripens early, is often one and one-half inches long, by one inch in diameter; soft, sweet and luscious throughout, with no hard core; ripe before late raspberries are gone. Should be mulched to keep berries from the ground. We highly recommend this variety.

Maxwell-It is as large or larger than Wilson's Early, and ripens as early as Early Harvest. Rich and luscious, melting in the mouth-no core whatever. The canes are exceedingly prolific, very low, stocky and strong, and free from rust, double blossoms, and all other diseases. 
Mercereau-Remarkable strong grower, upright, producing stout, stocky canes. Claimed to be the hardiest blackberry, standing uninjured 20 degrees below zero without protection. An enormous producer of extra size berries which are brilliant black and retain their color under all conditions; extra quality; sweet, rich and melting, without core. Unsurpassed as a shipper and keeper. Its season is early to midsummer.

Minnewaska-This valuable new berry has the following good qualities: It is extremely hardy, wonderfully productive, of excellent quality, being without the hard core so often found in blackberries, is very early, and continues in fruiting until very late.

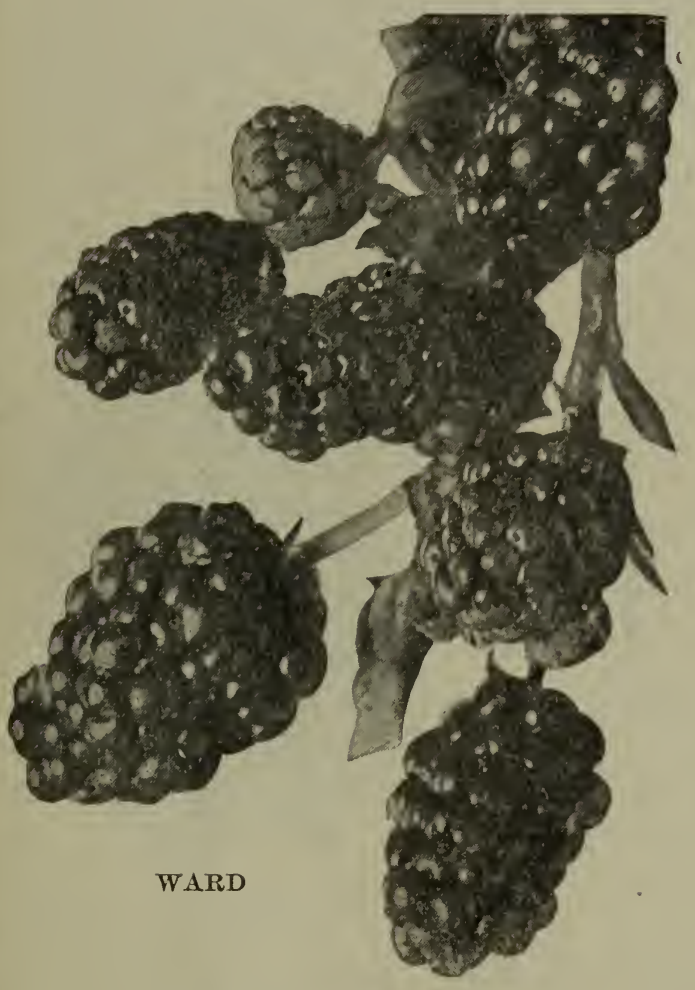

Rathbun-A strong, erect grower, and hardy; fruit is sweet, luscious, without a hard core; high flavor; jet black, small seeds; firm enough to ship and handle well. One of the largest size berries.

Snyder-Extremely hardy; enormously productive; medium size; no hard, sour core; half as many thorns as Lawton or Kittatinny, and they are nearly straight and short.

Taylor's Prolific-It is so extremely hardy as to have stood 30 degrees below zero unharmed. Berries large (nearly as large as Kittatinny) and of the highest quality. Canes of strong, spreading growth, and in productiveness it is simply remarkable, fully equaling in this respect the Snyder, which it nearly doubles in size. It ripens with Kittatinny.

Wachusett Thornless-Of fair size and excellent quality. Canes hardy, of strong, healthy growth. It is almost free from thorns, and fairly productive.

Ward-A New Jersey wonder. Undoubtedly a seedling of the Kittatinny, which it resembles, having all of its qualities and none of its defects. A healthy, strong grower with sturdy canes producing fine large fruit, black throughout, without core, and of excellent quality. Has never suffered from winter injury in New Jersey. An exceedingly prolific sort, the bushes being covered with its fine fruit, produced as many bushels per acre as the Wilson in its prime.

Wilson's Early-Large, sweet, fair flavored; very productive. Ripens up the fruit together, and is earlier than any other variety. Requires protection in some localities.

\section{OLIVES}

Picholine-Synonyms; Lechin, Coleasse, Piquette, Saurin, Plant d'Istres, Coias, Coiasse, etc. A variety much esteemed in California for its rapid growth; makes excellent oil, and stands as the best for picking.

Olives have been cultivated on the Coast of Georgia and South Carolina for many years, and an excellent quality of oil has been produced. A peculiarity of the olive is that it flourishes and its early bearing. The tree is also less subject to damage by insects than most other varieties and ripens its fruit in 12 months, thus bearing a crop annually; bears abundant crops on rocky and barren soils where no other fruit trees are successful. Olive trees begin to bear fruit at from 8 to 10 years of age, but should not be planted farther North than this section, where they are sometimes injured by excessive cold. 


\section{ASPARAGUS}

This earliest and finest of spring vegetable is among the easiest cultivated and most profitable. A bed once planted suffers no deterioration for thirty years or more, if it is properly attended to and well manured.

Cultivation-See that the ground is well drained, naturally or otherwise; work it up fine and deep, and make it very rich with well-rotted barnyard manure. Locate the plants eight inches apart in rows three feet apart. Spread out the roots in a trench made deep enough to permit their crowns to be covered with three or four inches of mellow earth. Give the bed liberal dressings of manure at intervals, and except near the seashore, three pounds of salt per square yard early every spring. Do not cut for use until the plants have grown two seasons.

Conover's Colossal-This variety is much superior in size and quality to any of the old common sorts, being remarkably tender and fine-flavored. The large green shoots, one to two inches in diameter, are sent up thickly from the crowns, making it a very profitable variety.

Palmetto-Until recently we believed that Conover's Colossal was the best sort known, but we are now forced to concede that the Palmetto is earlier and a better yielder and more even and regular in its growth, and that it will eventually supercede the old favorite.It has been tested both north and south, and has proven entirely successful in every instance.

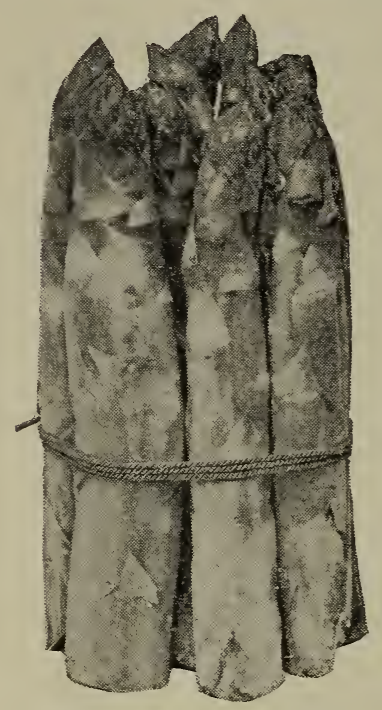

CONOTER'S COLOSSAL

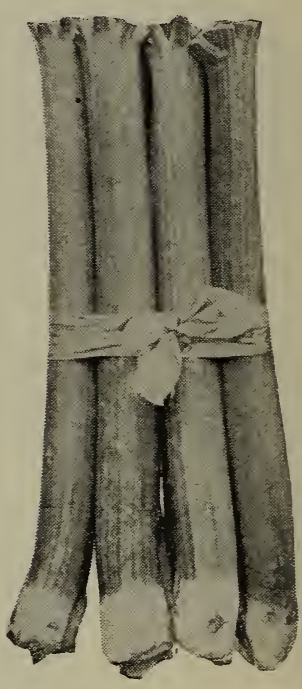

MYATT'S LINNEAUS

\section{RHUBARB OR PIE PLANT}

This deserves to be ranked among the best early products of the garden. It affords the earliest material for fine pies and fresh table sauce, continues long in use, and is valuable for canning. Make the ground rich and deep and thus secure a more tender growth.

Early Scarlet-Rather small, but early and good.

Myatt's Linneaus-Large, early, tender and fine. The very best of all.

\section{POMEG RANATES}

Purple Seeded or Spanish Ruby-Large yellow with crimson cheek; meat purplishcrimson, sweet and of best quality.

Sub-acid-Medium to large, dull red on yellow ground; meat sub-acid, and much esteemed in the preparation of cooling beverages. 


\section{MULBERRIES}

Downing's Everbearing-The beauty of this as a lawn or street tree is quite enough to commend it; but in addition it yields an abundant supply of its large refreshing berries for about three months. "I regard it as an indispensable addition to every fruit garden; and I speak what I think when I say I had rather have one tree of Downing's Everbearing Mulberry than a bed of Strawberries.' -Henry Ward Beecher.

New American-A new variety, forming a very beautiful tree; very hardy and productive. Superior to Downing.

Russian-A very hardy, rapidgrowing timber tree of great value, especially at the West. Introduced by the Mennonites. Foliage abundant; and said to be very desirable in the culture of silk worms. Fruit of good size and produced in great abundance.

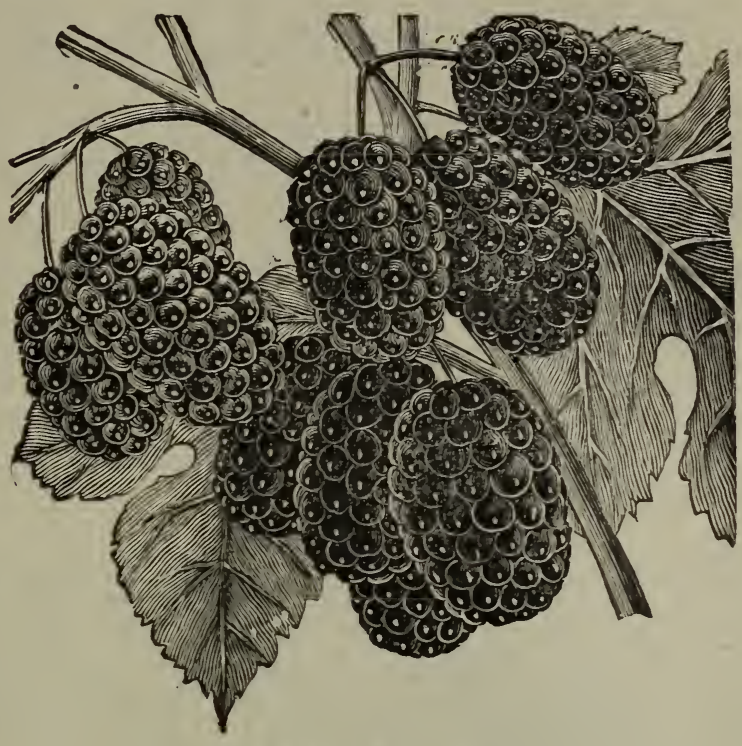

DOWNING MULBERRY

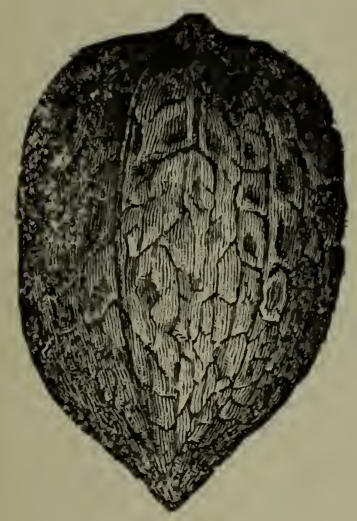

ENGLISH WALNUT

\section{NUTS}

For Description See Ornamental Trees

American Sweet Chestnut
Black Walnut
Butternut
English Walnut
Spanish Chestnut
Shell Bark Hickory

American Sweet Chestnut

English Walnut

Shell Bark Hickory

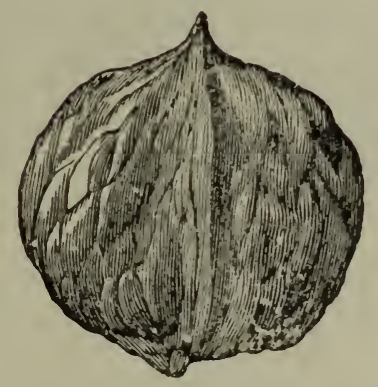

SHELL BARK HICKORY

\section{SCIONS AND STOCKS}

We are prepared to furnish nurserymen and those about starting nurseries, with Scions and Stocks of the very best quality and at low rates.

\section{ORANGE.}

Satsuma, or Oonshiu-A seedless variety of the Mandrin or Kid Glove class; of dwarf habit, and has withstood a cold of 20 degrees below freezing here.
Plants are all grafted upon Citrus Trifoliata, and may be said to be hardy in this latitude. Flowers are produced freely, but fruit does not set profusely. 


\section{ORNAMENTAL DEPARTMENT}

While most people appreciate well arranged and well kept grounds, large or small, many fail to realize that they too can have equally fine grounds. We frequently observe a few roses growing in thick turf, with no attention given to pruning or cultivating. Under such circumstances good results cannot be expected.

Aside from the pleasure of having fine trees, shrubs, vines and flowers in the grounds surrounding a home, few realize how much these add to the commercial value of the place. A purchaser having to decide between a house with a bare and unkept grounds and one surrounded by fine ornamentals, invariably chooses the latter at a marked advance in price, because he sees that he will at once enjoy what it would otherwise take some years to secure. Sagacious men are led by a knowledge of these facts to plant fine trees and shrubs about vacant lots they are intending to put upon the market. Lots thus planted readily secure purchasers at good prices when bare grounds go begging for buyers.

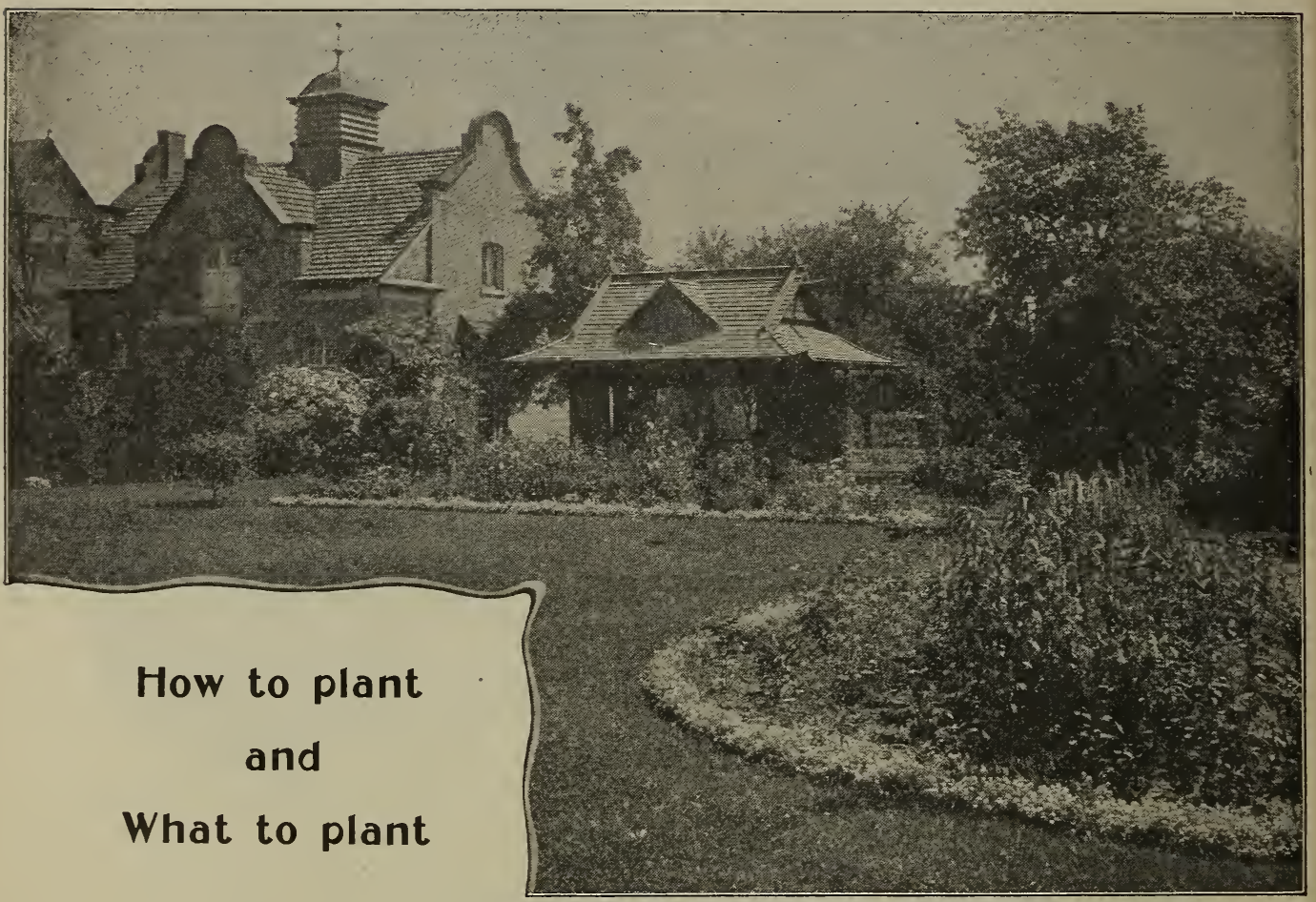

Do not make the mistake of planting at random all over the grounds. A fine, well cut lawn is one of the handsomest features of a place. Trees may be planted along a lane or avenue leading to the house, or dotted about the lawn on lines radiating from the house. This will secure light and air with good views from the house. Upright shrubs and roses should be planted in beds, each class by itself, about the borders of the grounds. These beds should be well cultivated and the plants annually pruned. When the growth of the plants has made them very thick, some should be taken out. It will not do to plant so little that years must elapse before a fine effect will be produced. A surplus should be planted at first and this gradually taken out. Vines should be planted near the house and allowed to climb upon and about it, or they may be trained on posts, arbors or stakes, placed in suitable location on the lawn.

A detailed list of desirable ornamental trees and shrubs would be little less than a recapitulation of our entire list. but as few have room for all, we here present a list of the most desirable in each class, and refer the reader to the proper places in the catalogue for descriptions of them. 
Flowering Trees, May-White Dogwood, Magnolias in variety, Judas Tree, Horse Chestnuts, Double Flowering Cherry; June-White Fringe, Laburnum, Mountain Ash, Thorns in variety, Catalpa, Syringaefolia, Lindens in variety, Virgila Lutea; July-American Sweet Chestnut.

Trees Valuable for their Form and Foliage-Cut-leaved Weeping Birch, Purpleleaved Birch, Kilmarnock Willow, Weeping Mountain Ash, Oak-leaved Mountain Ash, European Weeping Ash, Camperdown Weeping Elm, Purple-leaved Elm, European Linden, White-leaved Weeping Linden, Salisburea, Norway Maple, Wier's Cutleaved Maple, Imperial Cut-leaved Alder, Purple-leaved Beech, Fern-leaved Beech.

Evergreen Trees-Norway Spruce, Austrian Pine, Scotch Pine, Siberian Arbor Vitae, Irish Juniper, American Arbor Vitae, etc.

Upright Flowering Shrubs-April-Daphne Mezeron; May-Forsythia, Japap Quince, Double Flowering Plum, Dwarf Double Flowering Almonds. Spiraea Prunifolia, Lilacs in variety. Tartarian Honeysuckle, Cornus Mascula Variegata; JuneDeutzia Gracilis, Deutzia Crenata flore pleno, Viburnum Plicatum, Snowball, Wiegelia in variety, White Fringe, Syringa, Calycanthus (at intervals through summer), Red Dogwood, Herbaceous Paeonies, Spiraea Lanceolata, Tamarix Africana, Halesia, Japan Globe Flower; July-Spirea Callosa Alba, Spirea Callosa, Herbaceous

Paeonies; August and September-Althea in variety, Hydrangea Grandiflora.

Climbing and Trailing Shrubs-Clematis in variety (flower from June to November) Ampelopsis Veitchii, American Ivy, Climbing Honeysuckle in variety (flower all summer), Aristolochia Sypho (flower in May and June), Akebia Quinata, Wistaria. Evergreen Shrubs-Rhododendron in variety, Mahonia, Dwarf Box.

Roses-Climbing and Moss, blooming in June; Hybrid Perpetual and Perpetual Moss, blooming at intervals all summer; and tender roses, blooming constantly.

\section{UPRIGHT DECIDUOUS TREES}

Alder-(Alnus).

IMPERIAL CUT LEAF(Laciniata Imperialis)-A charming tree of stately graceful growth, having large and deeply cut foliage. Vigorous and hardy; one of the best lawn trees. Apple-(Sorbus).

CHINESE DOUBLE FLOWERING - (Spectabilis)Double white, fragrant flowers in cluster. May. Ash-(Fraxinus).

ACUBA-LEA VED - (Acubaefolia) - A fine tree with variegated gold-blotched leaves, valuable for planting near purple trees.

EUROPEAN-(Excelsior)A lofty tree of rapid growth, with spreading head, pinnate leaves and black buds.

EUROPEAN - FLOWERING -(Ornus) - Grows from 20 to 30 feet high; flowers greenish-white, fringe-like; produced early in June in large clusters at the ends of the twigs.

GOLD-BARKED - (Aurea) -A conspicuous tree at all times, especially in winter, on account of the yellow bark and twisted branches.

WILLOW-LEA VED - (Salicifolia) - A beautiful variety of fine form, rapid growth, having narrow, wavy leaves.

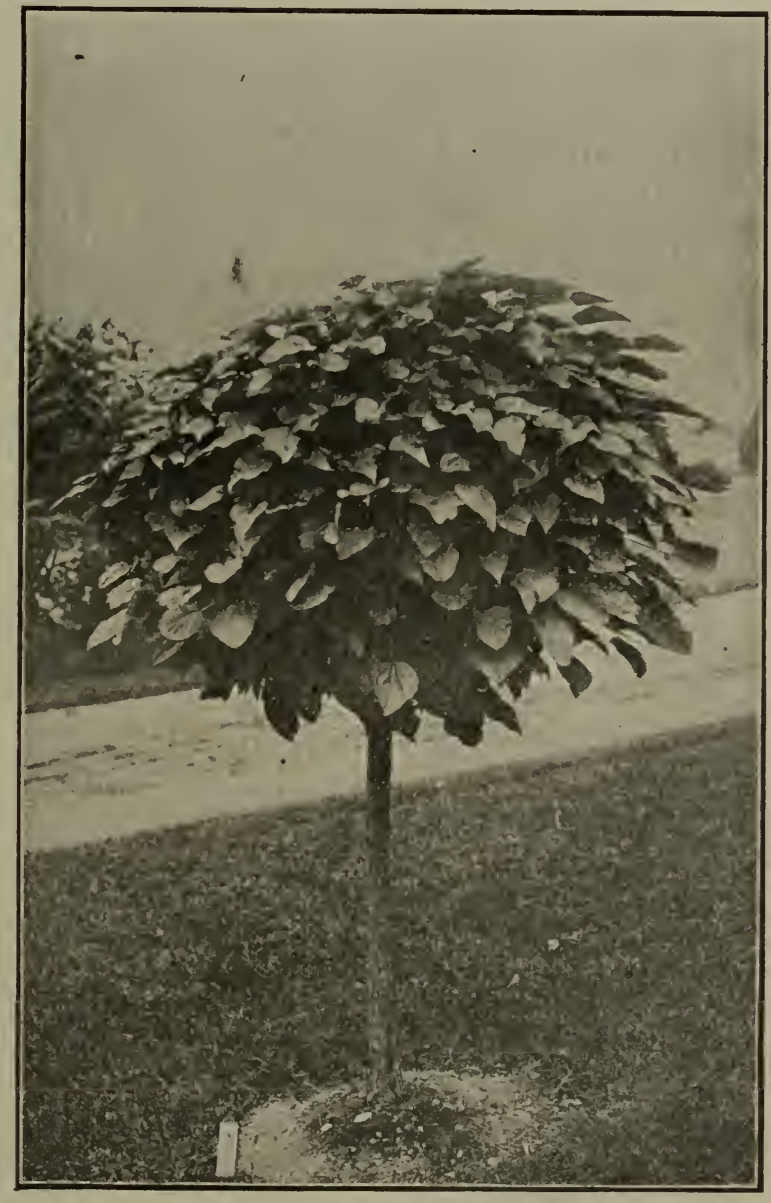

CATALPA BUNGEI 


\section{Beech (Fagus).}

EUROPEAN $\rightarrow$ (Sylvatica) -A beautiful tree, growing to the height of 60 or 80 feet.

FERN-LEAVED-(Heterophylia) - An elegant tree of symmetrical habit, having beautifully cut foliage.

PURPLE-LEAVED-(Purpurea) -Discovered in a German forest. An elegant vigorous tree, growing 40 to 50 feet high. Foliage deep purple, changing to crimson. Like all varieties of the Beech, this is difficult to transplant, hence small trees three feet high are preferable.

\section{Birch (Betula).}

EUROPEAN WHITE-(Alba)-A fine tree of moderate size, with silvery bark and slender branches.

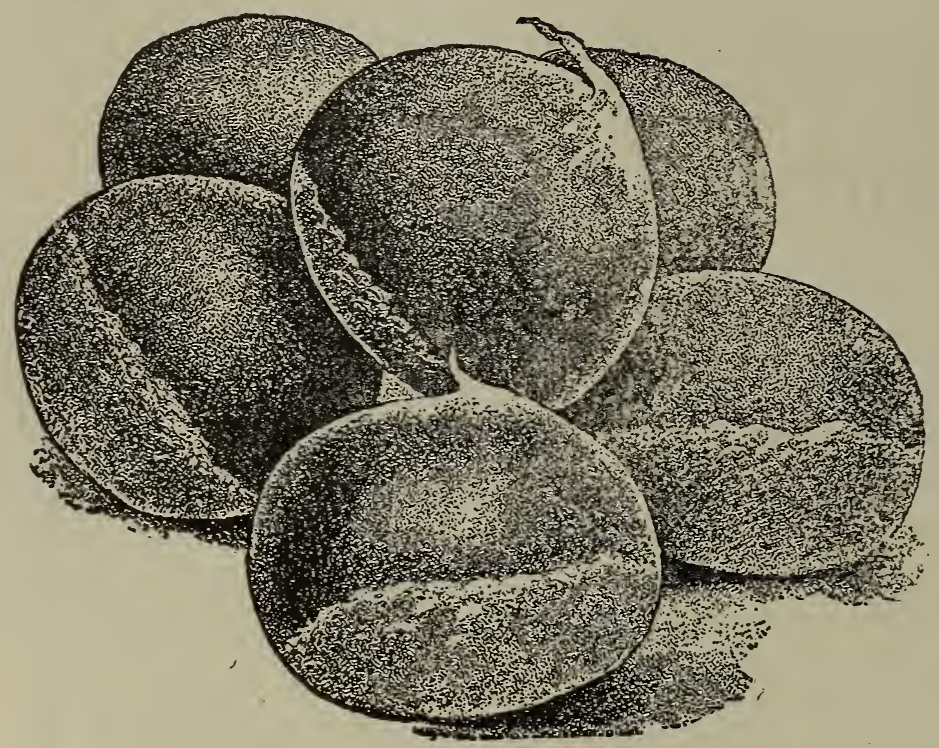

JAPAN CHESTNUTS

PURPLE-LEAVED-(Folis Purpureis) -A variety possessing the vigorous habits of the species, and having the rich purple foliage.

\section{Catalpa.}

BUNGEI-A species from China, of dwarf habit, growing only from 3 to 5 feet high. Foliage large and glossy,

SPECIOSA-A variety originating in the West; more upright and symmetrical in its growth than the common Catalpa (Syringaefolia), and blossoms two or three weeks earlier. Very valuable for timber, fence posts, railroad ties, etc., possessing wonderful durability. A very ornamental and valuable tree.
SYRINGAEFOLIA-A native of the South. A rapid-growing, beautiful tree, with very large, heart-shaped leaves and pyramidal clusters of white and purple flowers a foot long. Late in July.

Cherry (Cerasus).

DWARF WHITE-FLOWERING-(Humilis fl. pl.) -A variety of the Morello, with double white flowers. Both this and the succeeding are very ornamental.

LARGE DOUBLE - FLOWERING (Flore alba pleno) - A variety of the Heart Cherry, with pretty double flowers.

TEAS' JAPANESE HYBRID-It has large, luxuriant foliage, and large, handsome white flowers. In rapidity of growth, it rivals the most luxuriant $t r$ e e $s$ of temperate climates, while its hardiness $\mathrm{h}$ a s been demonstrated by its standin $\mathrm{g}$ uninjured twenty-five d e grees or more below zero.

Chestnut.

AMERICAN - A well-known forest and nut-bearing $\mathrm{tre}$ of great value for ornamental purposes.

SPANISH-A valuable species for both ornamental and $f r u i t$. It for $\mathrm{m} \mathrm{s}$ a handsome lawn tree and produces fruit three or four times as large as the American variety. Not hardy North of Philadelphia, $\mathrm{Pa}$.

NUMBO-A New Jersey seedling of the Spanish Chestnut, and claimed to be as hardy as the American.

JAPAN-Tree medium sized and decidedly ornamental. It fruits when very young; nuts are much larger than the Spanish and equal to it in flavor. Believed to be a great acquisition. Not hardy North of Philadelphia, $\mathrm{Pa}$.

\section{Dogwood.}

AMERICAN WHITE-(Florida) - A native tree of fine form and beautiful foliage, growing from 20 to 25 feet high, producing white flowers three inches in diameter early in spring before the leaves appear. A very desirable tree. 




AMERICAN ELM

RED FLOWERING - First disseminated by Thomas Meehan and considered a great acquisition.

Elm (Ulmus).

AMERICAN WHITE-(Americana)The noble, spreading, drooping tree of our own woods. One of the grandest and hardiest of park or street trees.

ENGLISH - (Campestres)-An erect, lofty tree, with rather small leaves.

PURPLE - (Stricta Purpurea) - A beautiful variety; leaves of rich purple color when young.

SCOTCH or WYCH-(Montana)-A fine spreading tree of rapid growth, foliage large.
Horse Chestnut (Aeculus).

RED-FLOWERING - (Rebicunda) Not so rapid or fine a grower as the white; foliage of a deep green and blooms later, with showy red flowers.

WHITE-FLOWERING -(Hippocas-tanum)-A very beautiful well-known tree, with round, dense head, darkgreen foliage, and an abundance of showy flowers in early spring.

Horse Chestnut, Smooth-Fruited (Pavia).

OHIO BUCKEYE-(Flava)-Has pale green leaves and showy yellow flowers. A fine small tree. A very crooked and irregular grower. 
SMALL BUCKEYE-(Rubra)-A small sized tree with dark red flowers; very crooked and irregular grower.

Judas Tree, or Red Bud (Cereis).

AMERICAN - (Canadensis) - A small growing tree, covered with delicate pink flowers before the leaves appear.

Laburnum (Cytisus).

GOLDEN CHAIN - Bears long pendant racemes of yellow flowers in June, showy and beautiful. Should be in every lawn.

\section{Larch (Larix).}

EUROPEAN - (Europaea) - An excellent, rapid-growing pyramidal tree; also valuable for timber. Small branches drooping.

Linden (Tilia).

AMERICAN - (Americana) - A rapid-growing, beautiful native tree, with very large leaves and fragrant flowers.

EUROPEAN-(Europaea)-A very fine pyramidal tree, with large leaves and fragrant flowers. Only desirable on large grounds. - -

WHITE or SILVER-LEAVED--(Argentea) - A handsome, vigorous growing tree; large leaves, whitish on the under side, and has a beautiful appearance when ruffled by the wind. One of the best.

Magnolia-One of the most beautiful species of flowering trees. Being difficult to transplant, small trees three or four feet high are preferable.

ACUMINATA-(Cucumber Tree) - A beautiful pyramidal growing native species, growing to the height of sixty of seventy feet, with large glossy leaves; flowers yellow, tinted with bluish purple.

CONSPICUA-(Chinese White)-Tree of medium size and shrublike growth. Flowers are large, pure white, very numerous, and appear before the leaves.

LENNEI-(Lennei's Magnolia) - Recently introduced; foliage large; flowers dark purple, and although not a symmetrical grower, a superb variety.

SOULANGEANA - (Soulange's Magnolia)-A French Hybrid; a rather irregular grower; foliage large, glossy and massive; flowers very large, three to five inches in diameter, white and purple. Very effective.

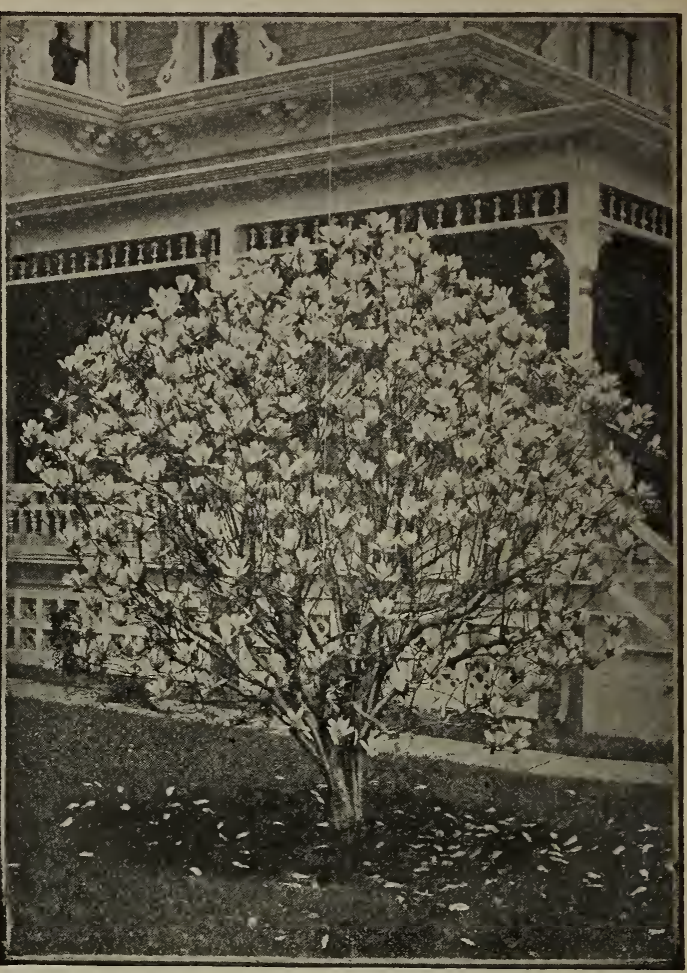

MAGNOLIA

SPECIOSA-(Showy Flowering Magnolia)-A good grower; tree generally round-headed and of fine form; flowers a little smaller and of a lighter color than those of Soulangeana, but being produced in wonderful profusion, this is one of the best varieties.

Maple (Acer).

ASH-LEA VED-(Negundo fraxinifolium)-A fine, rapid-growing variety, with handsome, light-green pinnated foliage and spreading head. Very hardy.

BLOOD-LEAVED JAPAN-Of dwarf habit and rounded form; foliage fivelobed and serrated; reddish crimson in June. A charming variety and one of the best of the Japanese Maples.

JAPAN MAPLE-(Acer Polymorphum)-Growth slow and shruby; foliage small, five-lobed and of a bright cheerful green in spring and summer, changing to a lovely dark crimson in autumn; perfectly hardy and one of the most beautiful and valuable of small sized trees.

NORWAY-(Plantanoides)-A native of Europe. Its large, compact habit, broad, deep green shining foliage, and its vigorous growth, renders it one of the most desirable species for streets, parks and lawns. 


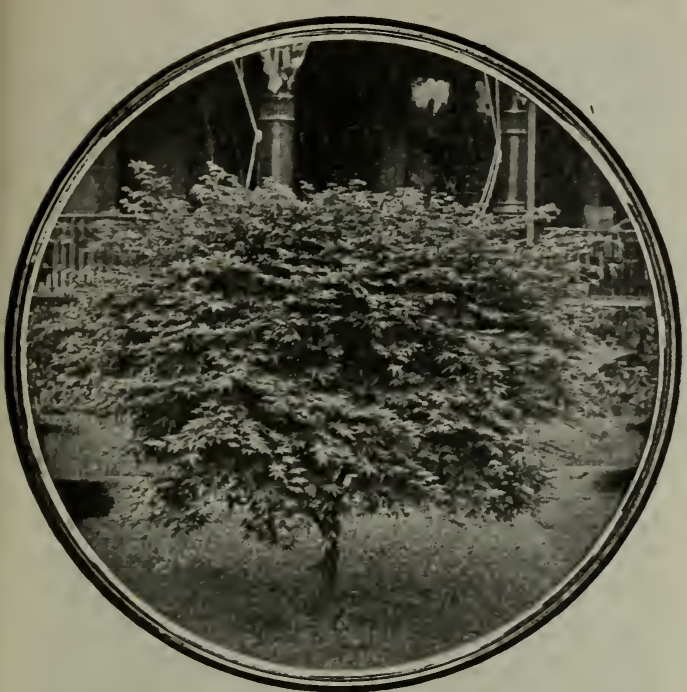

JAPAN MAPLE (ACER POLYMORPHUM)

WEIR'S CUT-LEAVED - (Weirii Laciniatum) -A Silver Maple with remarkable and beautiful dissected foliage. Of rapid growth; shoots slender and drooping, giving it a very graceful appearance. Should be in every collection. While it makes a large tree if undisturbed, it will bear any amount of pruning, and may be easily adapted to small lawns.

PURPLE-LEAVED SYCAMORE (Purpurea)-A strong, rapid grower; foliage deep green on the upper surface and purplish-red underneath. Produces a fine effect with other trees.

SCARLET-(Rubrum)-A native variety of medium size, producing deep red blossoms before the leaves appear. In Autumn the leaves change to a brilliant scarlet, rendering the tree very effective.

SUGAR, or ROCK-(Saccharinum)The well-known native variety, valuable both for the production of sugar and as an ornament in lining unpaved streets and avenues. A stately form and fine rich foliage render it justly popular as a shade tree.

SCHWEDLER'S NORWAY-(Schwedlerii) - A beautiful variety, with the young shoots and leaves of a bright purplish and crimson color, which changes to purplish green in the older leaves. One of the most valuable trees of recent introduction.

SILVER-LEAVED-(A. dasycarpum) -One of the most ornamental of the species; the under surface of the leaves a soft white. It is exceedingly rapid in its growth, often making shoots six feet long in a season; valuable as a street tree.
Mountain Ash (Sorbus).

EUROPEAN - (Aucuparia) - A fine hardy tree; head dense and regular; covered from July till winter with large clusters of bright red berries.

OAK-LEAVED - (Quercifolia) - A hardy tree of fine habit; height and breadth from 20 to 30 feet; foliage simple and deeply lobed. A very fine lawn tree.

Oak (Quercus).

PIN-The Pin Oak is undoubtedly the most valuable variety for all practical purposes. The foliage is dense, finely divided, of a beautiful shining green that colors to sparkling red and yellow in fall. The tree is easily transplanted and grows well on wet or dry ground; is in fact, the quickest growing of all the Oaks. As an avenue and street tree it is unequaled, and it is one of the best for park planting.

Olive (Eleagnus).

RUSSIAN OLIVE (E. Augustifolia)A very large shrub or small tree; leaves narrow and silvery white, flowers yellow and fragrant; very hardy.

Peach (Persica).

DOUBLE ROSE-FLOWERING-(Flore Rosea Pleno)-Flowers pale rose color, double; produced in great abundance and very handsome.

DOUBLE WHITE-FLOWERING (Flore Alba Pleno)-Very ornamental; flowers pure white; hardy.

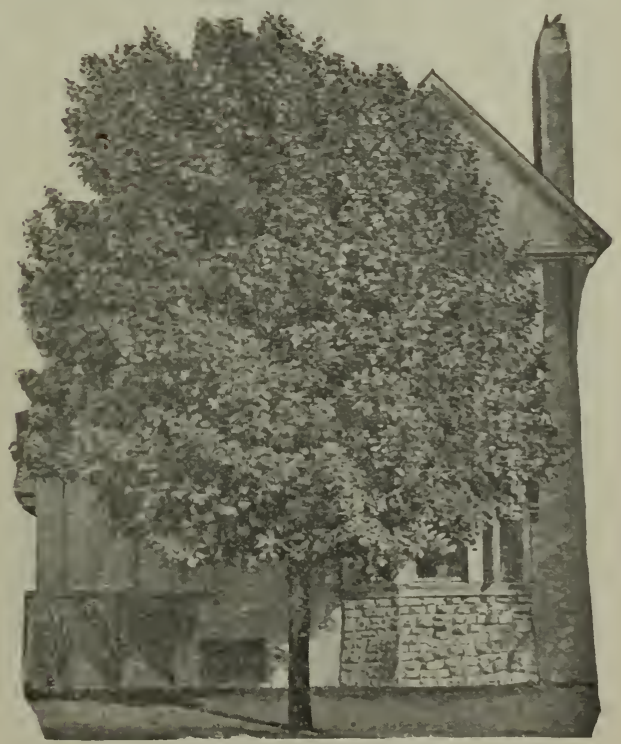

NORWAY MAPLE 
Poplar (Populus).

BOLLEANA-(New) - Pyramidal form, leaves dark green on upper side, brilliant silver beneath. Very beautiful; 8 to 9 feet.

CAROLINA-Pyramidal in form and robust in growth; leaves large, pale to deep green.

LOMBARDY - (Fastigiata) - Well known for its erect, rapid growth and commanding form; very desirable in large grounds and along roads to break the average height and forms of other trees.

SILVER-LEA VED - (Alba) - A tree of wonderful rapid growth and spreading habit; leaves large, dark rich greer above and white as snow beneath.

\section{Salisburia.}

MAIDEN HAIR TREE-(Adiantifolia)-One of the most beautiful of lawn trees. A native of Japan. Of medium size, rapid growth and rich, glossy, fernlike foliage. Rare and elegant.

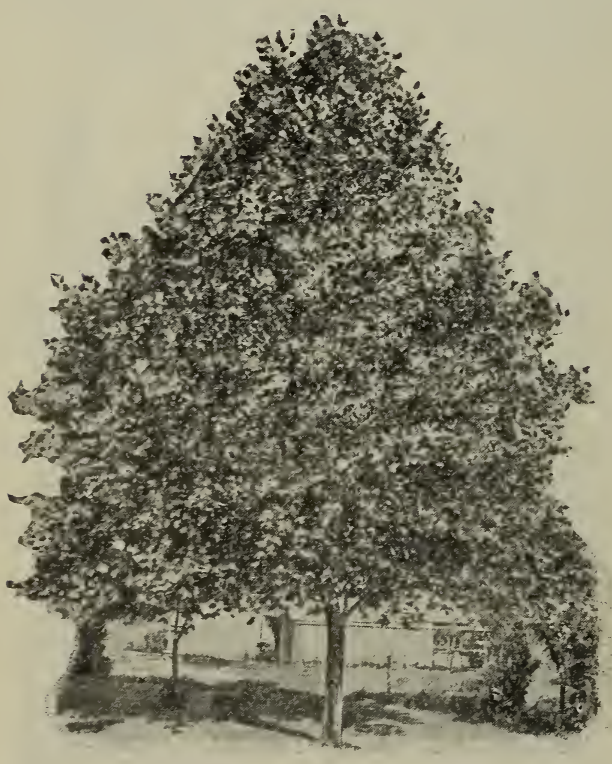

ORIENTAL SYCAMORE

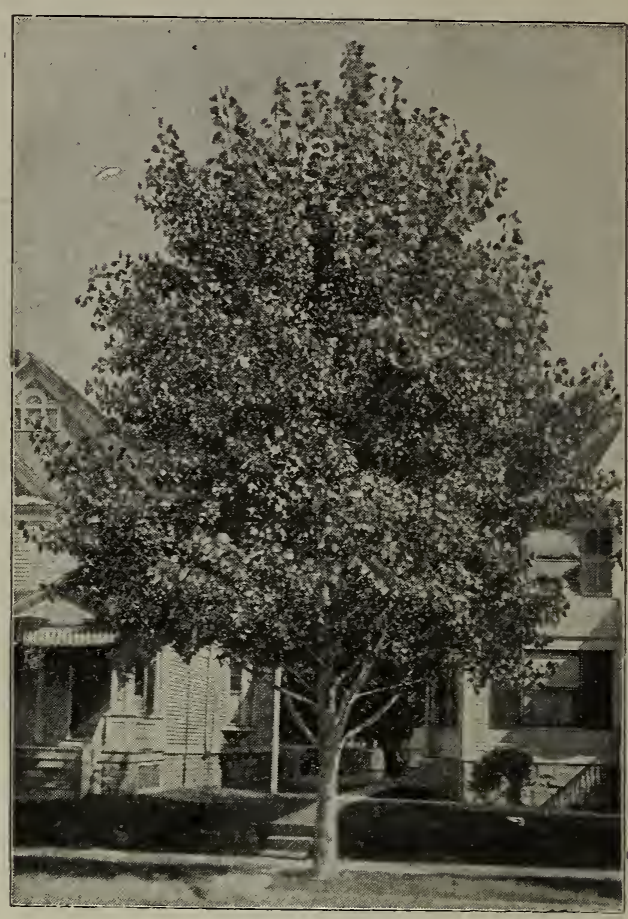

\section{Sycamore.}

CAROLINA POPLAR

ORIENTAL or PLANE TREEAs an ornamental tree for large grounds, or as a shade tree for street planting, this has no superior. A rapid grower, attains a large size, and is very graceful. Foliage heavy, and not subject to the ravages of insects. Especially valuable for city planting, as it is not affected by smoke or gas.

Thorn (Crataegus).

DOUBıE-SCARLET-(Coccinea fl. pl.)-Flowers deep crimson with scarlet shade; very double and considered larger than the double red; fine rich foliage.

DOUBLE-IVHITE-(Alba fl o r e pl.)-Has small double white flowers.

PAUL'S DOUBLE SCARLET(Coccinea fl. pl. Paulii)-Flowers large, deep carmine scarlet. Superior to any other variety.

Tulip Tree (Liriodendron).

TULIPIFERA-A magnificent native tree with broad, glossy, fiddle-shaped leaves and beautiful tulip-like flowers; allied to the Magnolias, difficult to transplant unless of small size. 
Texas Umbrella-A very rapid growing and spreading tree; has light colored, fern-like foliage. Not hardy in the Northern or Middle States.

Walnut (Jugans).

JAPAN WALNUT-Japan Walnuts are found growing wild in the mountains of Northern Japan, and the tree is, without doubt, as hardy as an oak. The nuts which are produced in extreme abundance, grow in clusters of 15 to 20 , and have shells thicker than the Persian Walnut, but not so thick as the Black Walnut. The meat is sweet, of the very best quality, with flavor like that of the butternut, but less oily and much superior. The trees grow with great vigor, assuming a very handsome form; needs no pruning, mature early, bear young, and are more regularly productive than the Persian Walnut. Having an abundance of fibrous roots the Japanese Walnut transplants as safely as the apple.
BLACK . WALNUT-(J. Nigra)-A native species of large size and majestic form; foliage beautiful, being composed of from thirteen to seventeen leaflets.

BUTTERNUT or WHITE WALNUT(J. Cinera)-A native tree of medium size, spreading head and gray. ish-colored bark.

ENGLISH, or MADERIA NUT-(J. Regia)-A handsome tree which produces fine fruit. Should be more extensively planted as it is quite hardy.

Willow (Salix).

ROSEMARY-LEAVED -- (Rosmarinifolia)-Budded five to seven feet from the ground, it makes a very handsome, round-headed small tree; branches feathery, foliage silvery.

Yellow Wood (Virgilia Lutea).

One of the finest of American trees, resembling the Robinias, with long racemes of white, sweet-scented flowers in June.

\section{WEEPING DECIDUOUS TREES}

Much attention is now given to this class of trees, and we place them separately for the convenience of our patrons. The superior grace and beauty of the weeping varieties render them especially adapted to yard, lawn or cemetery. No collection is complete without them; among ornamentals they have no superior.

\section{Ash (Fraxinus).}

EUROPEAN WEEPING-(Excelsior Pendula)-The common well-known sort; one of the finest lawn and arbor trees, covering a great space and growing rapidly.

GOLDEN BARK WEEPING-(Aurea Pendula) - An elegant variety; bark in winter as yellow as gold.

\section{Beech (Fagus).}

WEEPING-(Pendula)-A native of Belgium. A fine, vigorous and beautiful tree, attaining a large size; though ungainly in appearance when divested of its leaves, it is extremely graceful and effective when covered with its rich, luxuriant foliage.

Birch (Betula).

CUT-LEAVED WEEPING-(Pendula Laciniata)-Extremely vigorous and hardy. Mr. Scott, in his "Suburban Home Ground," says of it: "No en- graving can do it justice; like the palm tree of the tropics, it must be seen in motion, swaying in the lightest breeze, its leaves trembling in the heated summer air, its white bark glistening through the bright foliage and sparkling in the sun, to enable us to form a true impression of its character."

ELEGANT WEEPING - (Elegans) First exhibited at the Paris Exposition in 1879, where it attracted great attention. It has beautiful foliage and an elegant weeping habit. It is very desirable in grounds that admit variety.

YOUNG'S WEEPING - (Youngii) Originated near Milfred, Eng., where it was found trailing on the ground. Grafted into stems at some height, it forms pendulous heads, drooping to the ground in fine thread-like shoots; very beautiful. 
Cherry (Cerasus).

EVER-FLOWER-

ING WEEPING

(Semperflorens )

A very fine drooping variety with beautiful globular head that bears flowers and fruit all summer.

Elm (Ulmus).

CAMPERDOWN

WEEPING - A vigorous grower and forms one of the most picturesque drooping trees. Leaves large, dark-green and glossy, and cover the tree with a luxurious mass of verdure; very desirable.

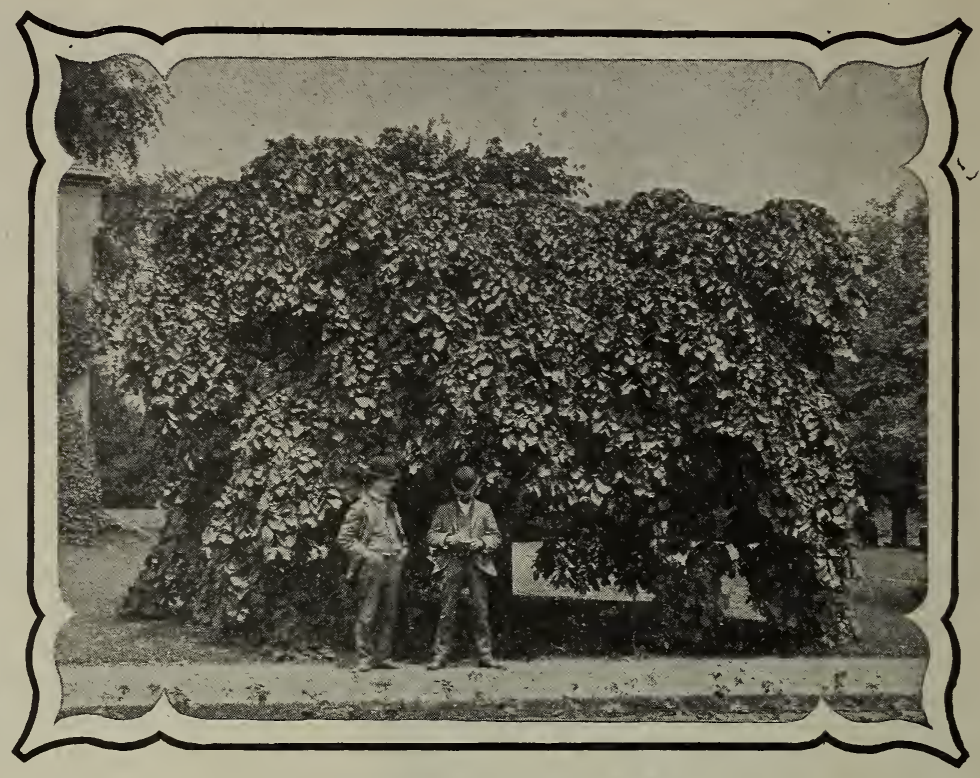

CAMPERDOWN WEEPING ELM

SCOTCH WEEPING-(Montana Pendula)-A vigorous growing tree with graceful drooping branches; very distinct.

Iinden, or Lime Tree (Tilia). WHITE-LEAVED WEEPING-(Alba Pendula)-A fine tree with large leaves and
drooping branches.

Mountain Ash (Sorbus).

WEEPING-- (Aucuparia

Pendula)--A beautiful tree, with straggling, weeping branches; makes a fine tree for the lawn; suitable for covering arbors.

Teas' Weeping Russian Mulberry.

A weeping variety of the now well-known Russian Mulberry; perfectly hardy in summer and winter; withstands ext $\mathrm{r}$ e m e heat and cold, and grows naturally in a very graceful form.

Poplar (Populus).

L A R G E-LE A V E D WEEPING- (Grandidenta Pendula) - A variety having when grafted standard high, long slender branches, like cords, which droop very gracefully; foliage large, dark shining green, and deeply serrated. One of the finest weeping trees in cultivation.

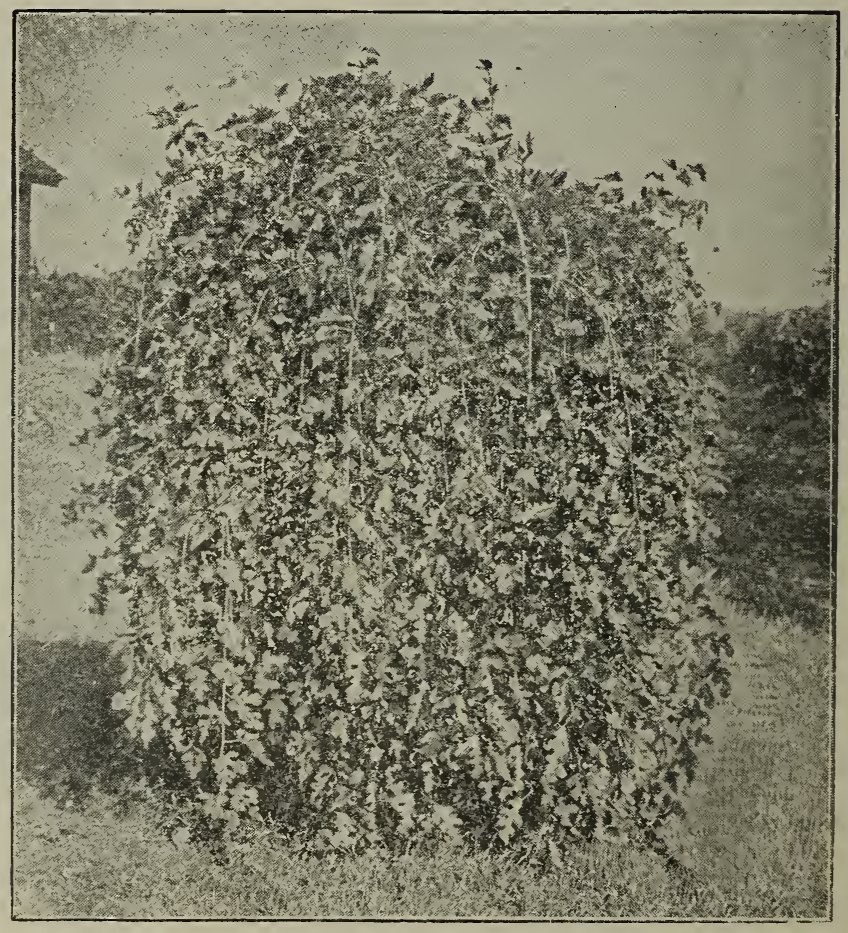

TEA'S WEEPING MULBERRY 
Willow (Salix).

AMERICAN WEEP.

ING - (Purpurea

Pendula)-An Ámer-

ican dwarf, slender-

branched species; grafted five or six feet high, it makes one of the most ornamental of small weeping trees; more hardy than the Babylonica.

B A B Y L O N I C A WEEPING - The well-known co m. mon weeping willow.

K I L M A R N O C K WEEPING - (Caprea Pendula)-An exceedingly graceful tree with large, glossy leaves; very hardy.

WISCONSIN WEEPING-Of drooping habit and hardier than Babylonica. Valuable on account of its ability to resist severe cold.

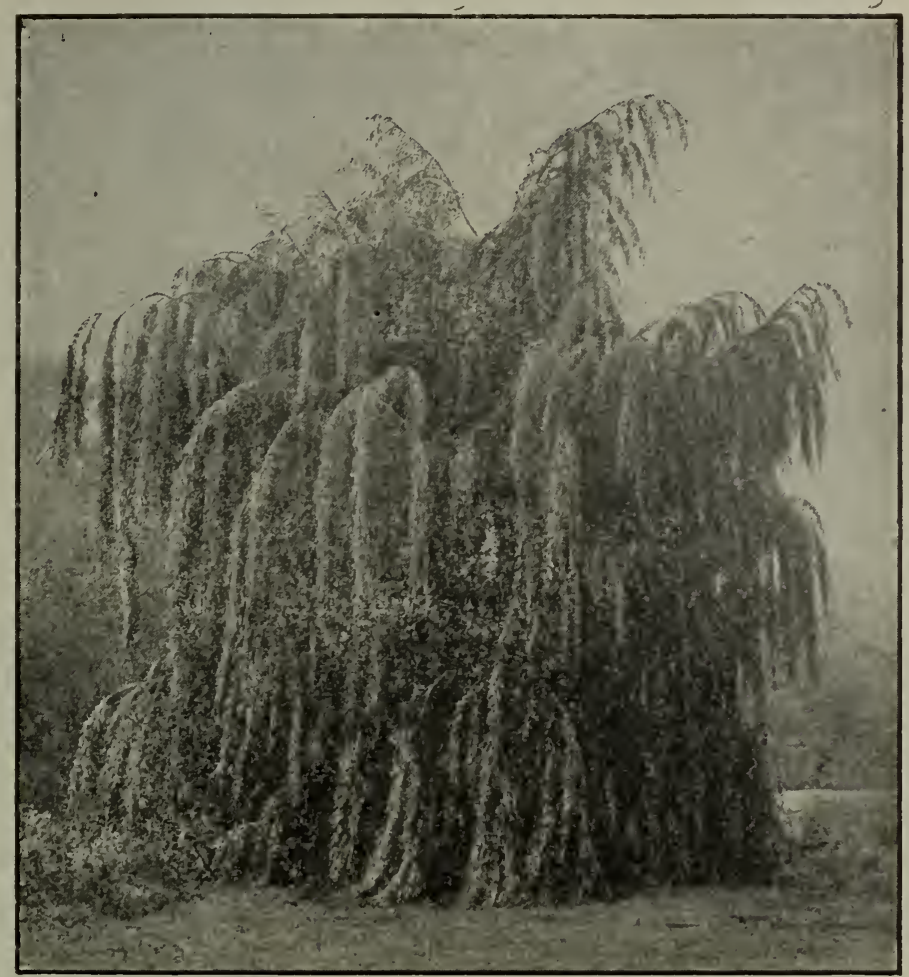

BABYLONICA WEEPING WILLOW

\section{EVERGREENS}

Evergreens are very desirable, but they are difficult to transplant, and both the time and manner of transplanting should be looked to. They should never be set in the fall after the growth of other trees has ceased. They may be set in August, or after they have started in May, but they should be subjected to as little exposure as possible and be set with great care.

\section{Arbor Vitae (Thuja).}

AMERICAN-(Occidentalis)-This is one of the very finest evergreens for hedges. It is very hardy, and if set at the proper time, with care and without due exposure, it may be relied upon to live, but small plants 12 to 18 inches high, which have been transplanted several times, are preferable. It bears shearing better than any other variety and may be made a very beautiful and dense hedge or screen to divide grounds or for any purpose where it is not required to resist cattle or other animals.

COMPACTA-A dwarf, compact variety, with a conical head; of bright green color; perfectly hardy. A native of Japan.

PYRAMIDALIS-(New)-Of upright, compact habit; similar to the Irish Juniper. Very desirable.
SIBERIAN-(Siberica)-One of the best of the genus of this country; exceedingly hardy, keeping color well in winter; growth compact and pyra. midal; makes an elegant lawn tree.

TOM THUMB-Similar to the HeathLeaved, but more desirable; remarkable for slow, compact growth; valu. able for planting in cemeteries and small places where large trees are not admissible.

Cedar, Red.

J. VIRGINIANA-A well-known American tree, with deep green foliage; makes a fine ornamental hedge plant.

Fir.

BALSAM or SILVER-Leaves dark green above, silvery beneath, retain. ing their color during the severest winter; grows rapidly and is very hardy. 
CONCOLOR-The Concolor is the Queen of Firs, clothed in robes of ermine and emerald. Its delicate, feathery foliage and handsome shades of coloring render this one of the most beautiful lawn trees.

Juniper (Juniperus).

AMERICAN UPRIGHT - A remarkable pretty little tree, with dense upright growth and handsome fastigiate form. The ends of the young shoots have a recurving habit, which renders the foliage quite graceful.

IRISH-(Hibernica)-Very erect and tapering in its growth, forming a column of deep green foliage; a pretty little tree or shrub, and for its beauty and hardiness is a general favorite.

SCALEY-LEAVED - (Squamata) - A very striking, hardy variety, spreading widely upon the ground and forming a very handsome evergreen bed.

SAVIN-(Sabina)-A low spreading tree, with handsome, dark green foliage; very hardy, and suitable for lawns and cemeteries; can be pruned to any desired shape and made very ornamental.

SWEDISH - (Suecica) - Similar to the Irish, though not so erect, with yellowish green foliage of somewhat lighter color than the preceding, forming a beautiful pyramidal small tree.

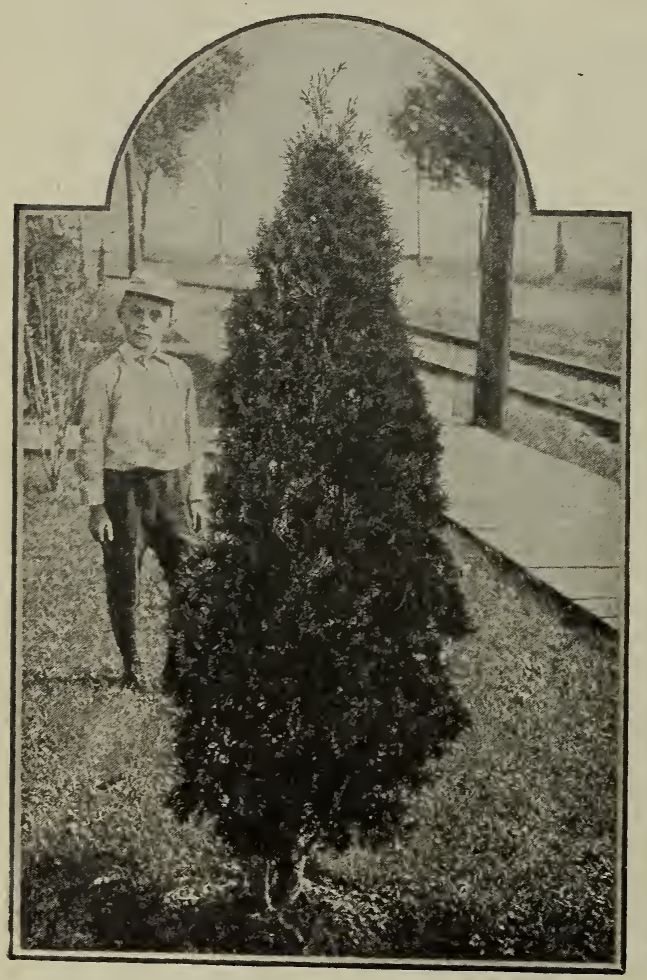

ARBOR VITAE PYRAMIDALIS
Pine (Pinus).

AUSTRIAN or BLACK-(Austriaca)A remarkable robust, hardy spreading tree; leaves long, stiff and dark green; growth rapid; valuable for this country.

MUGHO (Dwarf) - Very distinct, leaves short, stiff, a little twisted and thickly distributed over the branches; does not grow tall, but spreads over the ground, generally assuming a globular form; very dense.

SCOTCH-(Sylvestris) - A fine, robust, rapid-growing tree, with stout, erect shoots and silver-green foliage.

WHITE-(Strobus)-The most ornamental of all our native pines; foliage light, delicate or silvery green; flourishes in the poorest soils.

\section{Retinospora.}

RETINOSPORA PLUMOSA-An exceedingly handsome small evergreen from Japan, with a feathery, light green foliage.

RETINOSPORA PLUMOSA AUREALike the preceding, a plant of great beauty; foliage soft plume-like, of a golden yellow color; close and compact habit; should be in every amateur collection.

RETINOSPORA OBTUSA NANAOne of the finest of the family in showy arrangement of foliage, dwarf, dense, slow-growing habit, and depth of color.

RETINOSPORA OBTUSA N A N A AUREA - A beautiful golden form of above, foliage full, rich yellow, the deepest shade of all golden evergreens.

RETINOSPORA ARGENTEA - The bright green foliage is silver tipped and mottled with creamy white.

RETINOSPORA SQUARROSA-Dense growth; soft beautiful silvery blue foliage, arranged in spirals.

RETINOSPORA GRACILIS AUREAA graceful small ìree, the fern like young shoots of a lignt golden color.

Spruce (Abies).

COLORADO BLUE-(Picea Pungens) A rare, elegant tree with foliage of a rich blue. Ona of the most distinct and striking of all the spruce family. A free grower and perfectly hardy.

HEMLOCK or WEEPING-(Canadensis)-An elegant, pyramidal tree, with drooping branches and delicate dirk foliage like that of the Yew; distinct from all other trees. It is a beautiful lawn tree, and makes a highly ornamental hedge. 
NORWAY -(Excelsa) -A lofty, elegant, tree of perfect pyramidal habit, remarkably elegant and rich, and as it gets age, has fine, graceful pendulous branches; it is exceedingly picturesque and beautiful. Very popular, and deservedly so, and should be largely planted. One of the best evergreens for hedges.

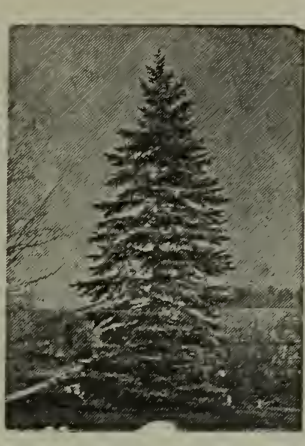

NORWAY SPRUCE
PYGMAEA-A dwarf variety of the Norway; grows from three to four feet high; very compact.

Yew (Taxis).

ERECT ENGLISH-A very fine pyramidal variety of the English Yew, with dark green toliage; hardy and desirable. Much used for hedges.

\section{UPRIGHT AND DECIDUOUS SHRUBS}

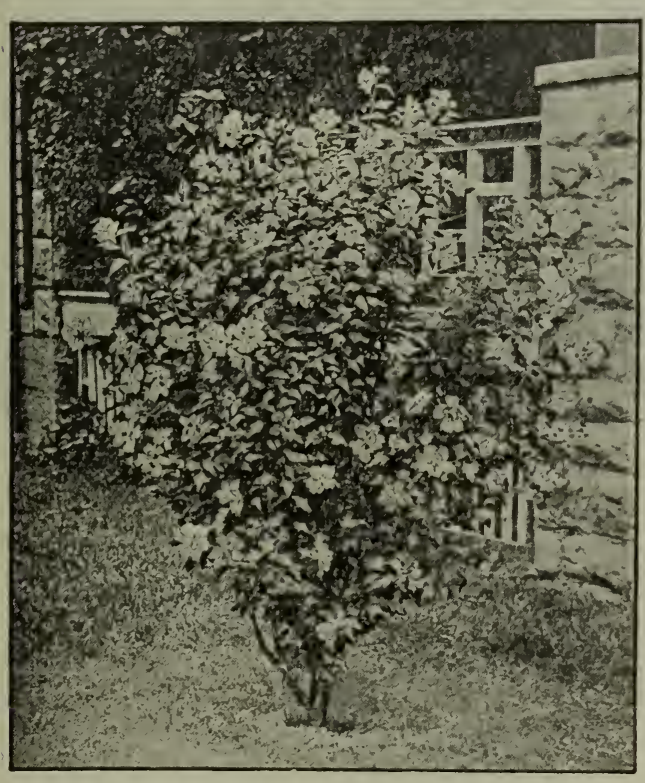

ALT'HEA

Althea (Hibiscus Syriacus).

The Altheas are fine, free-growing Howering shrubs of very easy cultivation. Desirable on account of flowering in August and September, when nearly every other shrub or tree is out of bloom. They are of good size, many colored, trim and attractive. Tree Altheas are very desirable, and the handsomest flowering tree we know of. Perfectly hardy and can be had in various colors if desired. Entirely free from all irsect pests; always gives delight and satisfaction. Require pruning each spring. We can supply double or single flowering Altheas in the following colors: Blue, Pink, Purple, Rec, White and Variegated.
Aralia.

SPINOSA-Imported trom Europe. A very wonderful largé shrub, or small tree, which resembles the Palm. It has dark green fern-like foliage of enormous size and bears long panicles of white flowers in August. It has been thoroughly tested and found perfectly hardy. Invaluable, as it gives a tropical appearance to the lawn.

JAPONICA-Of same family as above, but of Japanese origin. Very promising.

Azalea.

A. MOLLIS-A hardy species from Japan, and one of the most valuable flowering shrubs; flowers large and showy, yellow and different shades of red.

GHENT AZALEA-(A. Pontica)Grows three to four feet high, with small hairy leaves and yellow, red and orange flowers.

\section{Almond (Prunus).}

DOUBLE ROSE FLOWERING-(Japonica rubra fl. pl.) - A beautiful small shrub bearing in May, before the leaves appear; small, double rose-like flowers closely set upon the twigs.

DOUBLE WHITE FLOWERING(Japonica alba fl. pl.)-Produces beautiful white flowers in May. 


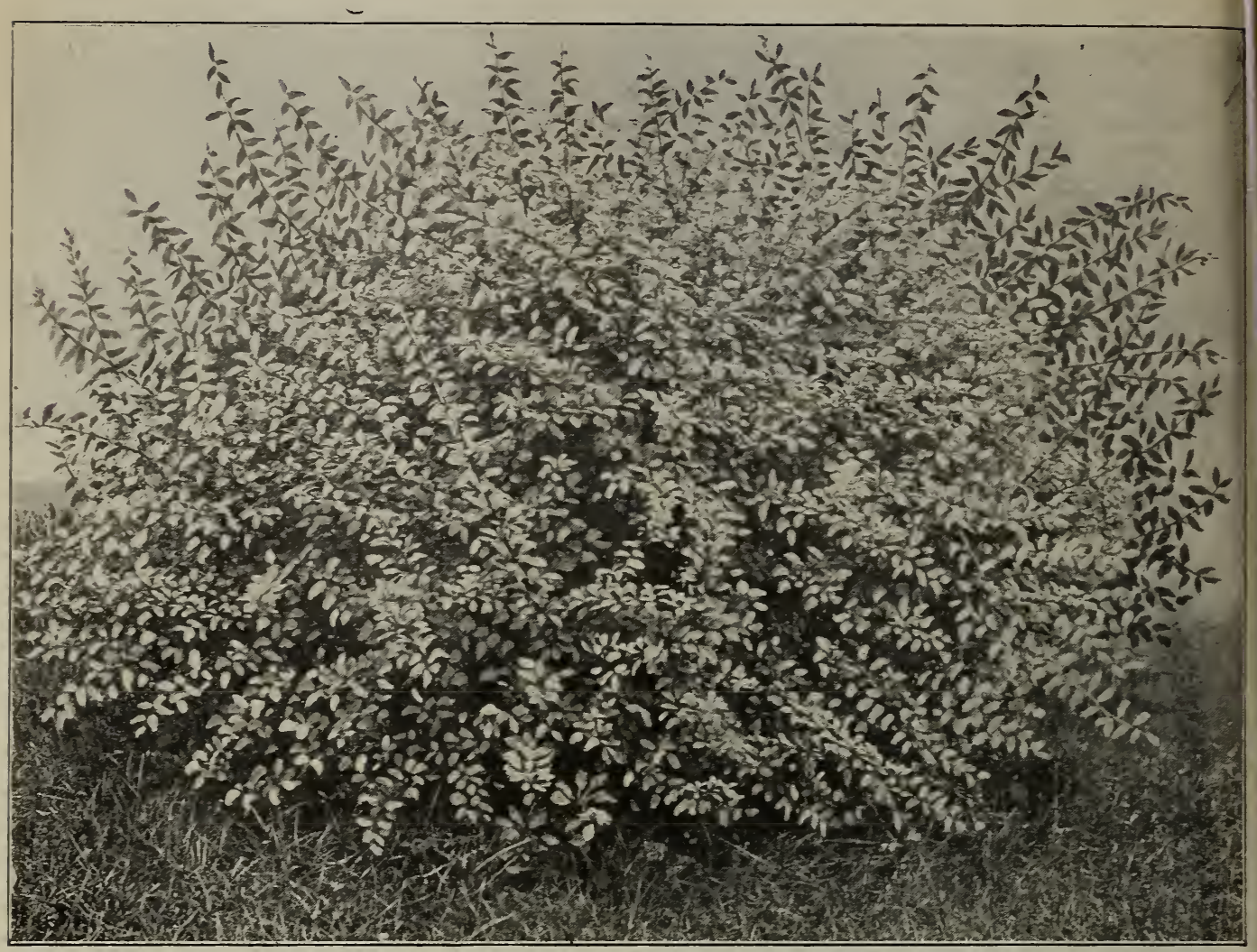

BARBERRY THUNBERGII

Barberry (Berberis).

PURPLE-LEAVED - (Purpurea) - A very handsome shrub, growing from three to four feet high, with violet purple leaves and fruit. Makes a fine ornamental hedge.

EUROPEAN-(Vulgaris)--A fine shrub with yellow flowers in drooping racemes produced in May or June, followed with orange-scarlet fruit.

THUNBERGII-A native of Japan. A pretty species, of dwarf habit, small foliage, changing to a beautiful coppery-red in autumn. Taluable as an ornamental hedge.

Calycanthus, or Sweet-Scented Shrub

The rood is fragrant, foliage rich, flowers of rare chocolate color, having a peculiarly agreeable odor. Flowers in June and at intervals afterward.

\section{Clethra.}

ALNIFOLIA-(White Alder) - A native shrub of low and dense growth; leaves abundant and light green; has numerous spikes of small, white fragrant flowers. Blooms abundantly in July.
Crab.

BECHTEL'S DOUBLE-FLOWERING AMERICAN CRAB-(Pyrus Augustifolia)-A medium-sized, hardy ornamental tree of great beauty. When in bloom this tree presents the appearance of being covered with roses, scenting the atmosphere for a long distance with a perfume equal to that of any rose. Unlike many other trees, it does not bloom until the leaves-are fully developed, which adds greatly to its beauty.

Currant (Ribes).

CRIMISON FLOTERING-Produces an abundance of crimson.flowers in early spring.

YELLOW FLOWERING - A native species with yellow flowers.

Daisy.

SHASTA-Probably no hardy plant has been so highly spoken of in American Horticultural Press as this production of Luther Burbank, the result of crossing our native field Daisy with some of the choicer European varieties, and bearing beautiful clear, glistening white flowers, and bloom ing continuously from early summer until late fall; perfectly hardy without protection, even in the most exposed location. 


\section{Daphne.}

COMMON MEZEREON-A native of Northern Europe. Small, branches erect, with clusters of pink flowers in March. The earliest flowering shrub we have.

WHITE - (Alba) - A variety with white flowers.

\section{Deutzia.}

This valuable species of plants comes to us from Japan. Their hardiness, luxuriant foliage and profusion of attractive flowers render them deservedly among the most popular of flowering shrubs. The flowers are produced in June in racemes four to six inches long.

- CRENATA - (Double-flowering, flore pleno)-Flowers double white, tinged with rose. One of the most desirable flowering shrubs in cultivation.

GRACILIS-(Slender Branched) - A charming variety introduced by Dr. Siebold. Flowers pure white and so delicate that they are very desirable for decorative purposes.

LEMOINEII-A hybrid obtained by Mons. Lemoine, of France, by crossing the well-known Deutzia Gracilis with Deutzia Parviflora. Flowers pure white, borne on stout branches which are of upright growth. Habit dwarf and free-flowering. A decided acquisition.

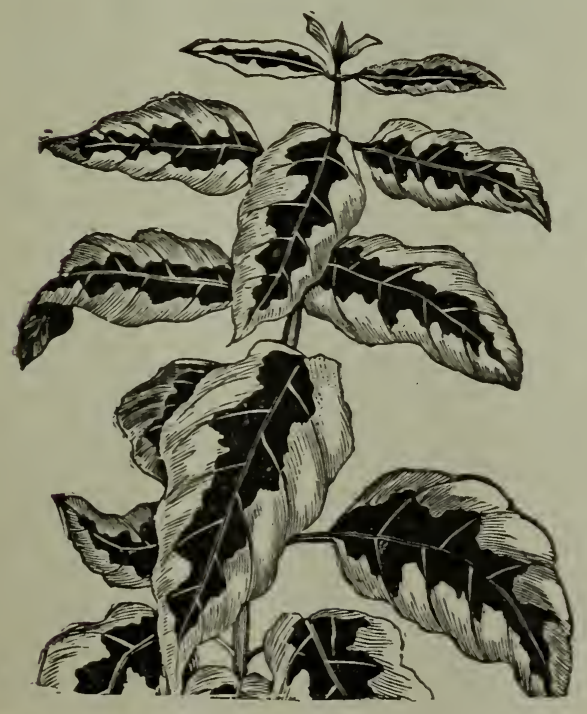

CORNUS-ELEGANTISSIMA VAR.

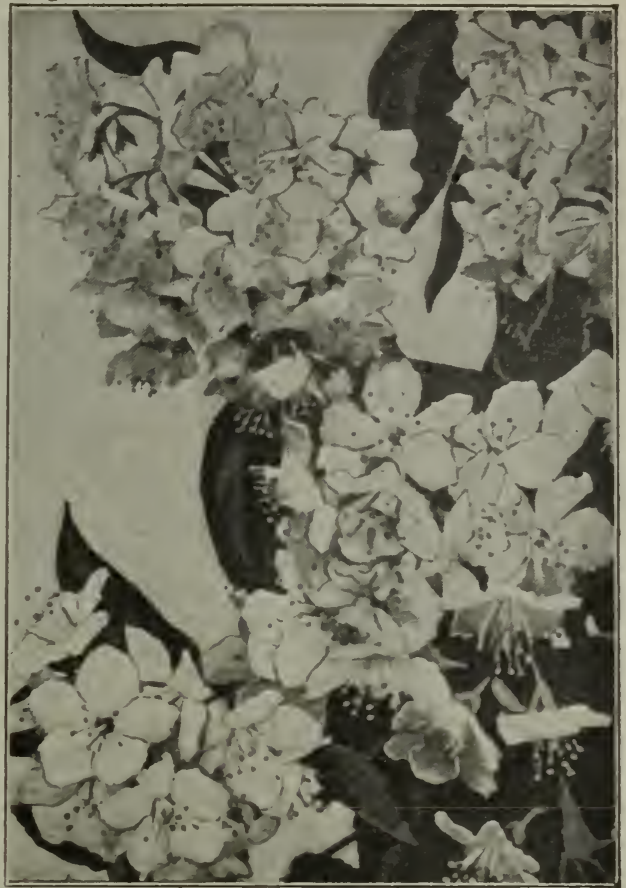

\section{DEUTZIA LEMOINEII}

PRIDE OF ROCHESTER-A new variety raised from Deutzia Crenata, and exceeding all others in size of flowers, length of panicle, profuseness of bloom and vigorous habit; a charming acquisition to the list of Deutzias.

SCABRA-(Rough-Leaved) - An exceedingly profuse white flowering shrub.

Dogwood (Cornus).

RED BRANCHED - (Sanguinea) - A native species, very conspicuous and ornamental in the winter, when the bark is a blood red.

VAR. CORNELIAN CHERRY (Cornus Mascula Variegat a)A small tree or shrub producing clusters of bright yellow flowers early in spring before the leaves appear. Has beautiful foliage, variegated with white. Decidedly the prettiest variegated shrub in cultivation.

ELEGANTISSIMA VARIEGATA-An improvement on the preceding, and one of the finest variegated shrubs; of rapid growth, foliage beautifully marked with creamy white and tinged with red, while some leaves are entirely white; should be in every collection. 
Elder (Sambucus).

A well-known shrub, which blos soms in spring and afterward is covered with handsome berries; there are several varieties.

GOLDEN-(S. Aurea)A beautiful variet $y$ with light yellow leaves, which hold their color well and render the plant very conspicuous and effective.

Euonymus-(Burning Bush or strawberry tree)A very ornamental and showy bush, whose chief beauty consists in its brilliant berries, which hang in clusters from the branches until midwinter; berries rosecolored; planted with a background of Evergreens the effect of contrast is very fine.

\section{Elaeagnus Longipes.}

A well-known shrub of spreading habit, dark green foliage, silverywhite beneath, with yellow flowers and bright red fruit that is beautiful as an ornament on the bush and is esteemed very highly by many for use in place of cranberries. Within the last few years there have been many thousand plants imported from Europe, the demand having far exceeded the supply of American nurserymen.

Filbert.

PURPLE-LEAVED-(Corylus avellana atropurpurea)-A vigorous shrub, with large, deep purple leaves; very ornamental; produces good fruit.

F'ringe.

PURPLE or SMOKE TREE- A very elegant and ornamental large shrub, with curious, hair-like flowers, which, being a pinkish brown color, give it the names, "Purple Fringe" and "Smoke Tree." The blossoms are in July, sometimes literally covering the tree and remaining all summer.

WHITE-(Chinonanthus Virginica)An entirely different plant from the preceding; has handsome, large foliage and racemes of delicate white flowers that hang like finely-cut shreds or fringe of white paper. 


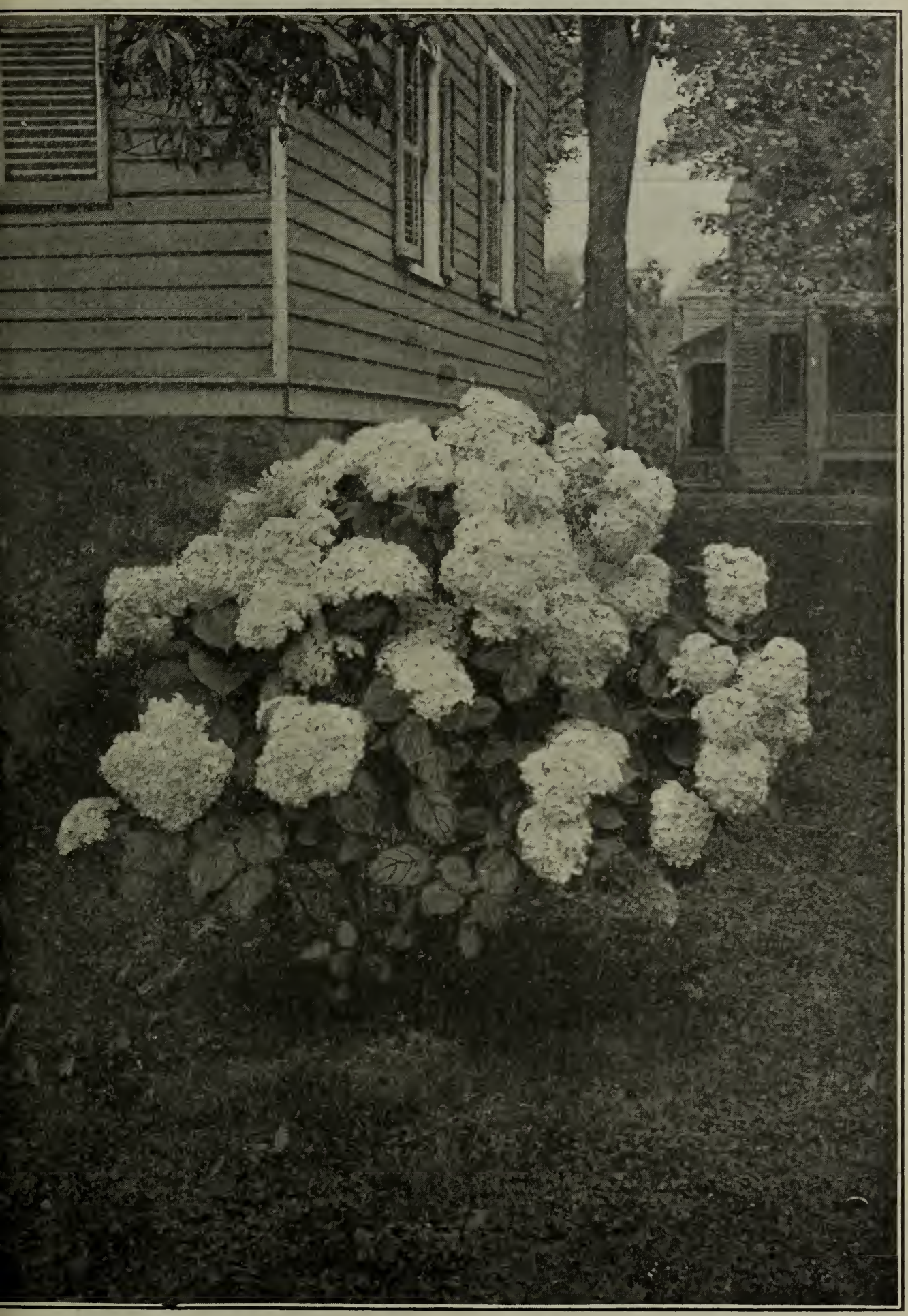


Honeysuckle (Lonicera).

RED TARTARIAN - A beautiful shrub; vigorous and producing large bright red flowers striped with white, in June.

WHITE TARTARIAN-A large shrub having white flowers, in May and June.

Hop Tree, or Shrubby Trefoil (Ptelea).

A large shrub, or small tree, of rapid growth and robust habit. Fruit winged and in clusters. Flowers in June.

\section{Hydrangea.}

ARBORESCENS STERILIS (Hills of Snow)-This superb new Hydrangea is a variety of the hardy native species $H$. arborescens, commonly found "wild" in most of the states east of the Mississippi river. The sterilis is likewise absolutely hardy and is, moreover, of easy culture and is an exceedingly prolific bloomer. A five year old plant has produced one hundred and twenty-six perfect blooms at one time.

OTAKSA-Foliage a beautiful deepgreen. Produces immense clusters of rose-colored flowers in profusion, in July. Should be planted in tubs.

PANICULATA GRANDIFLORA - A fine, hardy shrub, growing to the height of eight or ten feet; flower white, in great pyramidal panicles a foot long, produced in August or September, when most other shrubs are out of bloom.

RED-BRANCHED-The highest authorities pronounce it the grandest plant for the house or verandas that has ever been introduced. The wood is distinct red and the flowers pink, of great beauty and immense size.

THOMAS HOGG-A half-hardy variety of great beauty; flowers pure white, produced from July to September. Requires some winter protection.

TREE FORM HYURANGEA-The Hydrangea Paniculata Grandiflora is one of the very finest of hardy shrubs, but when grown in standard or tree shape it is especiallv showy and striking. It forms a graceful and dwarfish tree, not reaching more than eight to ten feet in height, and is extremely effective for lawn decorations, whether standing singly or in masses. The immense trusses of bloom appear at just the time when other flowers are scarce, and last from the first of August until frost comes. It is entirely hardy and very easy to grow.
Japan Maple.

Very beautiful and very expensive.

BLOOD-LEAVED-A bushy shrub with deep cut leaves. The young growth is of a very brilliant crimson. One of the best.

GOLDEN-LEAVED-A beautiful variety. Foliage richly shaded with gold and green.

RED-LEAVED-An interesting variety. The young growth is of a deep red, changing to a brilliant green.

ROSE PINKED LEAVED-A slow grower, with small leaves margined with rosy pink; distinct and beautiful.

\section{Lilac (Syringa).}

The lilacs are well-known, beautiful shrubs, indispensable in every collection.

PERSIAN LILAC - (S. Persica) Grows four to six feet high, foliage small and flowers a bright purple.

PERSIAN WHITE LILAC-(S. Persica, var. Alba)-Delicate white, fragrant flowers, shaded with purple.

PURPLE LILAC-(S. Vulgaris)-The well-known purple variety; always a standard sort.

WHITE LILAC-(S. Vulgaris Alba)Too well-known to need description; flowers white and fragrant.

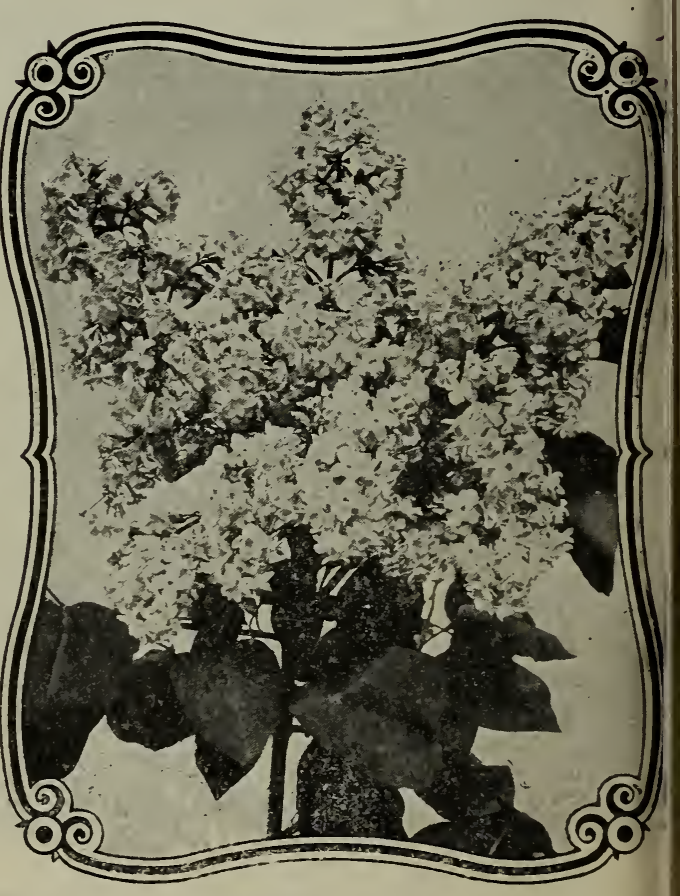

PERSIAN LILAC 


\section{Single Lilacs.}

CHARLES X.-A strong rapid growing variety; large shining leaves; flowers reddish purple.

LUDWIG SPAETH-Flowers a dark purple borne in large panicles; the best of the dark varieties.

MARIE LE GRAYE-Large panicles of white flowers; the finest white lilac.

RUBRA DE MARLAY-Flowers very dark lilac.

\section{Double Lilacs.}

ALPHONSE LAVALLE-Flowers a bluish lilac.

BELLE DE NANCY-Flowers pink with a white center.

MME. ABEL CHATENAY-Flowers white, borne in compact panicles.

MME. CASIMIR PERIER-Flowers are white, borne in large, graceful panicles.

PRESIDENT GREVY-Panicles large, pale blue and very double.

VILLOSA or TREE-A remarkable new species from Japan, becoming a good-sized tree; foliage dark-green, glossy; Howers small, feathery, but formed in great panicles, often 18 inches long; very light straw color; blooms a month later than other lilacs.

WEEPING-New-A beautiful weeping tree; produces large clusters of beautiful, intensesy sweet flowers. A great acquisition.

\section{Plum (Prunus).}

DOUBLE FLOWERING-(P. Triloba) -A very desirable shrub, introduced from Japan. Flowers semi-double, of delicate pink, upwards of an inch in diameter, thickly set; hardy; flowers in May.

PRUNUS PISSARDII-The tree is a decided contrast in itself. The leaves, as they first appear, on the tips are a beautiful orange color, and they mature to a rich purple, clear and distinct, groming darker as the season advances. The leaves remain untu late in the fall-a decided contrast to other shrubs.

\section{Privet.}

AMOOR RIVER-(L. Amurense)-A valuable ornamental shrub for hedges and borders; very hardy; foliage glossy green and holds its color almost the entire year; will stand shearing to any extent.

CALIFORNIA-(L. Ovalifolium)-The well-known variety; vigorous and hardy; deep glossv green; useful for hedges and borders.
Quince Japan (Cydonia).

SCARLET-Has bright scarlet crimson flowers in great profusion, early in spring. One of the best hardy shrubs; makes a beautiful ornamental hedge.

BLUSH-A beautiful variety with white and blush flower.

Snowball (Viburnum).

COMMON-(V. opulus) - A well-known favorite shrub of large size, with globular clusters of pure white flowers in the latter part of May.

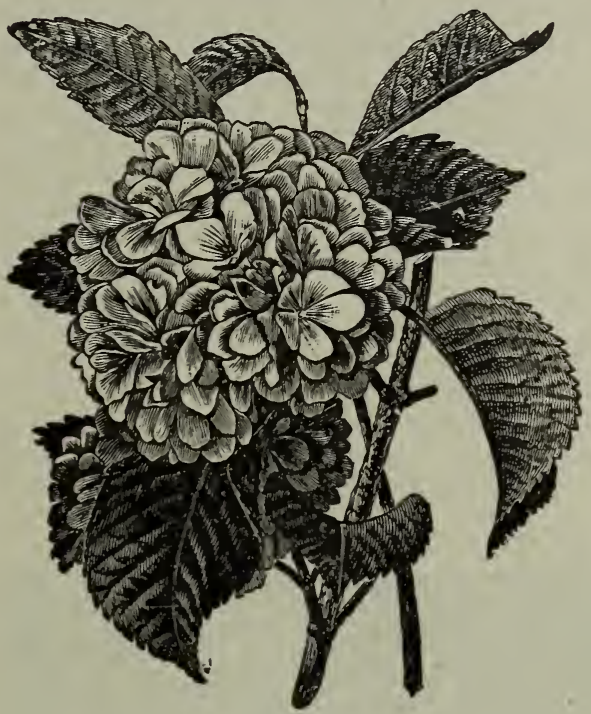

JAPANESE SNOWBALL

JAPANESE-(Virburnum Plicatum)From North China; has very rich deep green foliage, of handsome form and beautiful globular heads of pure white flowers, quite distinct from those of the common sort. A very desirable shrub.

TREE SNOWBALL-(Viburnum Opulus)-This is the old fashioned and very showy Snowball grown in tree form and is one of the best early bloomers. It is very conspicuous and attractive in tree form and far more handsome than the bush form. This is the first time this grand old favorite has been offered in tree form, and we recommend it as a novelty; worthy of a place everywhere.

Spiraea (Meadow Sweet).

ANTHONY WATERER-This beautiful variety has the same habits as its parent, the Bumalda. It blooms about the close of June, continuing throughout the entire season. It is useful for edging, planting in masses or a single specimen, where a low, bushy shrub is required. 


\section{Spirea,}

B I L L A R D I - (Billard 's Spirea) Rose-colored; blooms nearly all sum. mer.

BLUE SPIREA-(Caryopteris Mastocanthus)-A fine, low-growing shrub, from China, growing from 2 to 3 feet; blooms during entire season and until late in the fall; flowers of the most pleasing rich lavender blue. A great acquisition.

BUMALDA-New, and considered one of the finest or this class. Flowers brilliant pink with variegated foliage.

CALLOSA ALBA-A white flowering variety of dwarf habit; very fine; remains in flower all summer.

GOLDEN-LEAVED-(Foliis Aureis)A beautiful dwarf plant with goldenyellow toliage. It keeps its color the entire season, and creates a very pleasing effect among other shrubs.

PRUNTFOLIA FLORE PLENO - A beautiful shrub from Japan, with double white flowers in May.

REEVESII, or LANCE-LEAVED-A charming shrub, with narrow-pointed leaves and large, round clusters of white flowers that covers the whole plant.

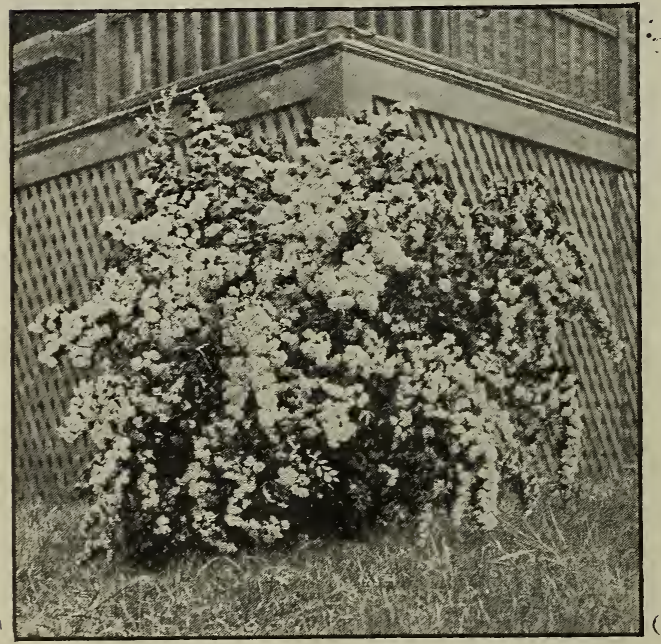

\section{SPIREA VAN HOUTTEI}

VAN HOUTTEI-(S. Van Houttei)The most showy of all the Spiraeas, and one of the very best flowering shrubs in cultivation. The plant is a rather tall, upright grower, with long, slender branches that aroop gracefully with their. weight of foliage and flowers. Flowers pure white, in great clusters and whorls, forming cylindrical plumes two or three feet long. This is one of the hardiest of all the Spiraeas
Strawberry Tree. (See Euonymus.)

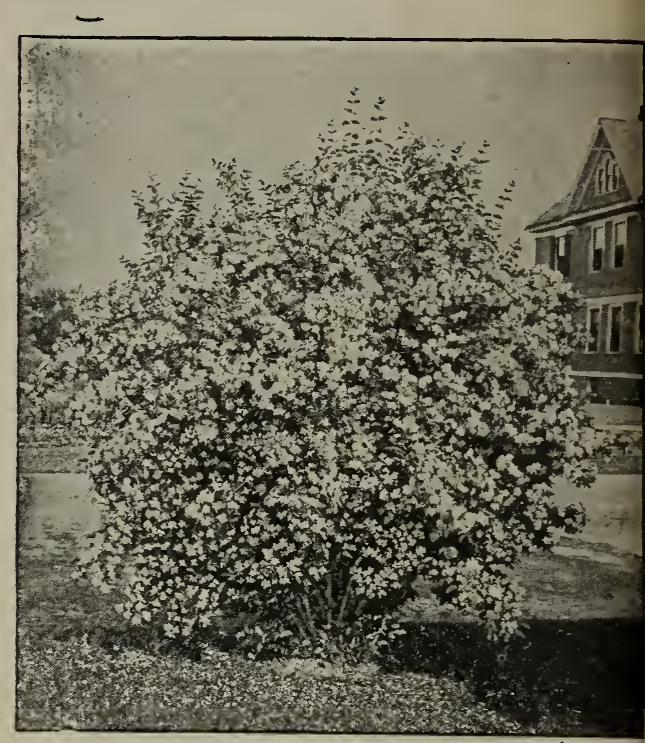

Syringa.

\section{SYRINGA}

MOCK ORANGE-(Philadelphia coronarius)-A well-known very hardy shrub, with showy white flowers, which are very fragrant.

LARGE FLOWERING-(E. Grandiflorus)-Large, showy flowers. A valuable variety.

GOLDEN-LEAVED-(P. Foliis Aureis) A beautiful new variety with bright yellow foliage, which affords pretty contrasts with other shrubs, especially with the purple-leaved variety.

VARIEGATED-A magnificent new variety, with beautiful foliage, somewhat similar to the Variegated Altheas. Very rare as yet; a great acquisition.

Symphoricarpus (St. Peter's Wort, or Wax Berry).

RACEMOSUS-(Snowberry) - A wellknown shrub, with small pink flowers, and large white berries that hang on the plant through part of the winter.

VULGARIS (Red-fruited or Indian Currant Coral Berry) - A shrub of very pretty habit. Foliage, flowers and fruit small; fruit purple; hangs all winter.

\section{Tamarix.}

AFRICANA - A beautiful shrub with small leaves similar to the Juniper; flowers are pink, small and delicate, borne on long spikes; blooms in May. 


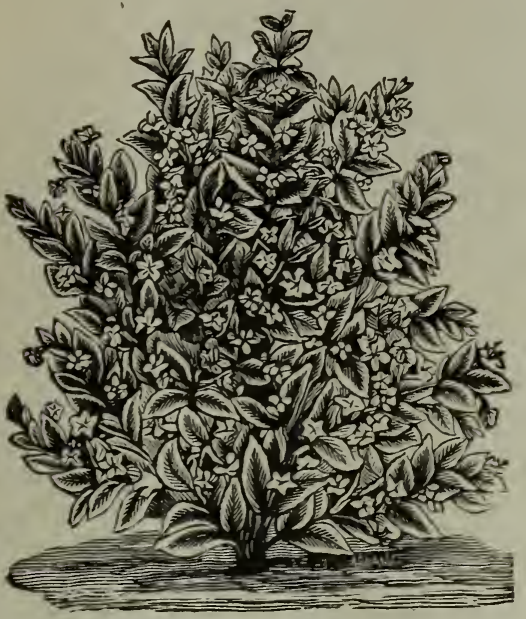

WEIGELA, VAR. LEAVED

Weigela (Diervilla).

AMABILIS, or SPLENDENS-Of robust habit, large foliage and pink flowers. Blooms freely in Autumn; a great acquisition.

CANDIDA-Thought by some to be the best of all. Of vigorous habit, an erect grower; flowers pure white, produced in great profusion in June, the plants continuing in bloom through the summer.
DESBOISII-A beautiful variety with deep rose-colored flowers resembling Roses, but much darker.

EVA RATHKE-New. A remarkably free bloomer. Very distinct color, being a rich red, quite different from anything heretofore offered.

FLORIBUNDA-(Crimson Weigela)The flowers are dark crimson, with white stamens projecting from them reminding one somewhat of Fuschia flowers. It blooms in the spring with other Weigelas, but if plants are topped off after young growth has been made, they bloom profusely in the fall. One of the best.

HORTENSIS NIVEA-Flowers pure white, retaining their purity during the whole time of flowering; foliage large.

ROSEA-An elegant shrub with fine rose-colored flowers. Introduced from China by Mr. Fortune, and considered one of the finest plants he has discovered. Quite hardy; blooms in May.

VARIEGATED-LEAVED-(Fol Variegata)-Leaves bordered with yellowish-white, finely marked; flowers bright pink.

\section{EVERGREEN SHRUBS}

Ashberry (Mahonia).

HOLLY-LEA VED - (Aquifolia) - A most beautiful shrub, with glossy, holly-like leaves, which change to brownish-green in winter, with clusters of bright, yellow flowers in May.

Box (Buxus).

DWARF - (Suffruticosa) - The wellknown variety for hedge.

TREE BOX-Several sorts.

\section{Euonymus.}

RADICANS VARIEGATA-A charming shrub of dwarf and trailing habit; it is perfectly hardy and has foliage beautifully variegated with silvery white tinted with red in the winter. Unsurpassed for edging.

Rhododendron-In variety.

These are the most magnificent of all evergreen shrubs, with rich, green foliage and superb clusters of showy flowers. They require a peaty soil, free from lime, and a somewhat shaded situation; they do best near the seashore and will repay all the care that may be bestowed in preparing a bed suited to their wants.
Thorn, Evergreen-(Crataegus Pyracantha)-The Evergreen Thorn is a low, bushy shrub, compact, dwarf habit, retaining its foliage well. Bears orange-scarlet berries; makes a pretty hedge.

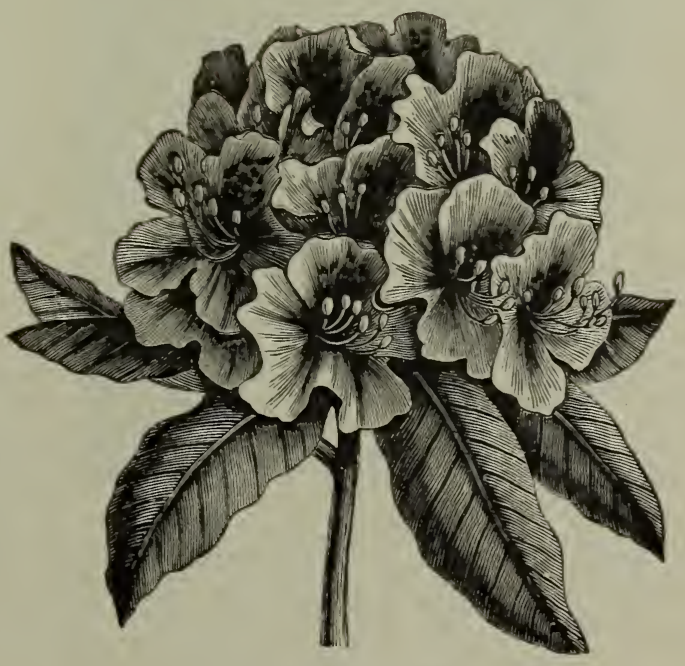

RHODODENDRON 


\section{HARDY CLIMBING SHRUBS}

Ampelopsis.

AMERICAN IVY, or VIR G IN I A CREEPER (A. Quinquefolia) - A native vine of rapid growth, with large, luxuriant foliage, which in Autumn assumes the most gorgeous crimson and purple coloring.

A. VEITCHII-(Veitchi's Ampelopsis) -Japan. Leaves a trifle smaller and more ivy like in form than the preceding. Overlapping each other they form a dense sheet of green. It grows rapidly and clings to the surface of even a painted brick wall with great tenacity. The foliage is especially handsome in summer and changes to a scarlet crimson in autumn. For covering walls, stumps of trees, rocks, etc.

WOODBINE or ENGELMAN'S IVY (A. Quinquefolia, var. Engelmanni) -A type of Quinquefolia, which has long been desired. It has shorter joints and smaller and thicker foliage. It is better equipped with tendrils, by which it will climb walls of stone or brick as closely as the Veitchii (Boston Ivy). It should be planted in the Central and Northwestern states, in place of the Veitchii, as it is perfectly hardy, withstanding heat and cold much better.

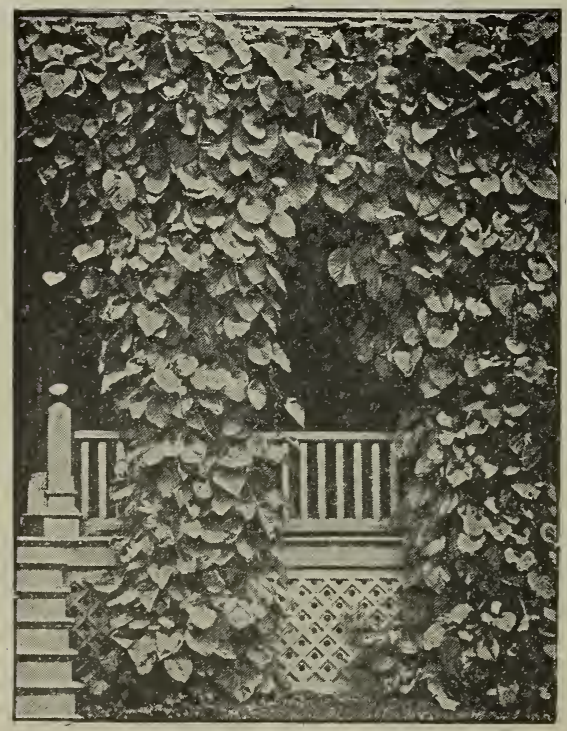

DUTCHMAN'S PIPE

Aristolochia, or Dutchman's Pipe.

SIPHO-A rapid growing vine, with magnificent foliage, ten to twelve inches in diameter, and curious pipeshaped, yellowish-brown flowers.
Hydrangea, Climbing.

A handsome, rapid-growing vine with almost the characteristic in flower and foliage of the Hydrangea Paniculata. It clings with tenacity to any object by which it may be planted and attains a height of fifty feet; has large white flowers.

Honeysuckle (Lonicera).

CHINESE TWINING-(Japonica) - A well-known vine, holding its foliage nearly all winter. Blooms in July and September and is very sweet.

H A L L'S JAPAN - (Halleana) - A strong vigorous evergreen variety, with pure white flowers, changing to yellow. Very fragrant, covered with flowers from June to November.

JAPAN GOLDEN-LEAVED - (Aurea reticulata) - A handsome variety, having foliage beautifully netted or rariegated with yellow.

MONTHLY FRAGRANT-(Belgica)Blooms all summer. Flowers red and yellow. Very sweet.

SCARLET TRUMPET--(Sempervirens) A strong grower and produces scarlet, inodorous flowers all summer.

Ivy.

COMMON ENGLISH-(Hedera Helix)

The Ivy, being an evergreen, not very hardy, and suffering from exposure to the winter sun, should be planted on the north side of buildings or walls. It is very effective grown in pots for inside decoration.

Iatrimony Vine (Lycium).

A vigorous hardy climber. It will soon cover any desired space. It has dark green foliage and beautiful flowers and loads of small berries, which are seen in all parts of the country at Christmas time.

Trumpet Vine-(Bignonia Radicans)-A splendid climber and hardy, with clusters of large trumpet-shaped, scarlet flowers in August.

Wistaria.

CHINESE PURPLE - (Sinensis) - A most beautiful climber of rapid growth and producing long, pendulous clusters of pale blue flowers. When well established, makes an enormous growth; it is very hardy and one of the most superb vines ever introduced.

CHINESE WHITE-(Sinensis Alba)Introduced by Mr. Fortune, from China, and regarded as one of his greatest acquisitions. Rather tender. 


\section{CLEMATIS OR VIRGIN'S BOWER}

None among hardy perennials exceed in beauty and effectiveness the finer sorts of Clematis. As a climber for the veranda, a screen for fences, for pillars along garden walks, for training on walls or arbors, in masses on rockwork, or cultivation in pots, it has no rival among strong-growing blossoming plants. The Clematis should be grown in rich, deep, sandy loam, and be well mulched with rotten manure in winter. Tho richest sheets of bloom and largest flowers are obtained where it has partial shude and a liberal supply of water at the roots.

\section{SIMALL FLOWERING.}

Coccinea-Distinct from other varieties; bright coral scarlet flowers. July to Ociober.

Crispa- $A$ handsome native variety, with nostin', Lell-shaped lavender purple tragrant tlorvers, which are an inch or a little more in lenoch and breadth with revolute sepals; very distinct.

Paniculata-A native of Japan. A beautiful and rapid growing climber, which in a very brief time will cover any ordinary veranda. The flowers are small, pure white and delightfully fragrant, and are borne in enormous masses, almost concealing the foliage. Entirely free from blight and regarded as a great acquisition.

\section{LARGE FLOWERING.}

Alexandra-This is one of the continuous blooming sorts of real merit. The flowers are large and of a pale reddish-violet color. Desirable. July to October.

Baron Veillard-(New)-Flowers large and very abundant; a handsome rose color. One of the best of its class.

Duchess of Edinburg-This is one of the best of the double white varieties. The flowers are pure white, four inches across; very deep. They are also remarkably sweet scented.

Fair Rosamond-Free growing and handsome. The flower is fully six inches across; the color is white with a bluish cast, having a light wine-red bar up the center of each sepal. Flowers very fragrant.

Gem-A new and perpetual-blooming variety. The flowers are of a deep lavender blue. June to October.

Henryii-This is the finest of all white Clematis and should find a place in every collection. It is not only a vigorous grower, it is a remarkably free and continuous bloomer, beginning with the earliest and holding on with the latest. Flowers large, of a beautiful creamy white, with reddishchocolate anthers. June to October.

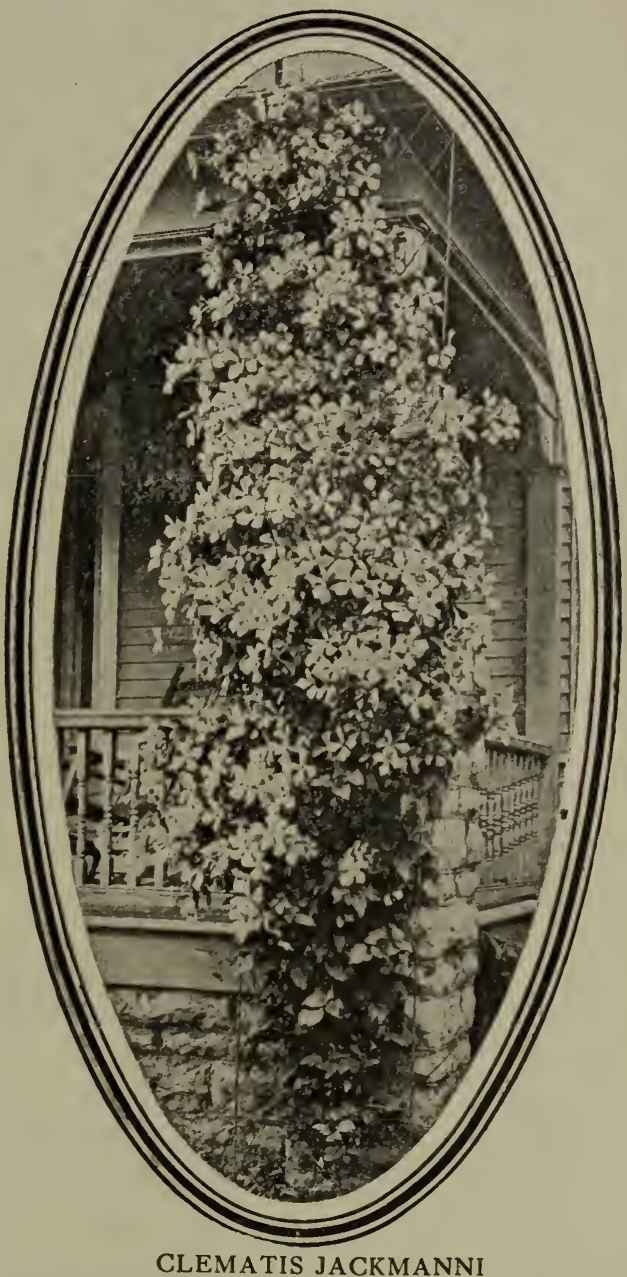

Jackmanni-This is, perhaps, the bestknown of the fine perpetual Clematis, and should have credit for the great popularity now attending this family of beautiful climbers. The plant is free in its form of growth and an abundant and successful bloomer, producing flowers until frozen up. The flowers are large, of an intense violet-purple, remarkable for its velvety richness. Jackmanni has no superior and very few, if any equals. July to October. 
John Gould Veitch-Sent from Japan in 1862. The flowers are very handsome, distinct, large, double, and of light blue or lavender color. June.

Kermessina Splendida-This is the most profuse bloomer of all the Clematis, commencing in early summer and continuing through the season; literally covered with scarlet crimson flowers. Not subject to blight, and is a vigorous grower.

Languinosa Candida-A variety of the above, having large delicately-tinted grayish-white flowers, which become white after the flowers are fully expanded. One of the best. July to October.

Lawsoniana-One of the finest of all; a vigorous grower and continuous bloomer. The flowers are very large, often nine inches in diameter. Opening a rich glistening, rosy purple, they gradually change to a mauve purple. - June to October.

Lucie Lemonie-New. Flowers white, double, large and well formed; composed of 75 to 90 petals; very showy. Junis:

Madam Edouard Andre-First seen in this country at the World's Fair, at Chicago; flowers large, abundant and a beautiful crimson purple. Beyond doubt the finest of its class.

Miss Bateman-One of the most charming of the spring flowering hybrids, having large white flowers with chocolate-red anthers and somewhat fragrant. May and June.

Prince of Wales-This is one of the very profuse flowering varieties of vigorous habit; showy and free. The flow. ers are of a deep purple, with a red bar in the center of each flower leaf.

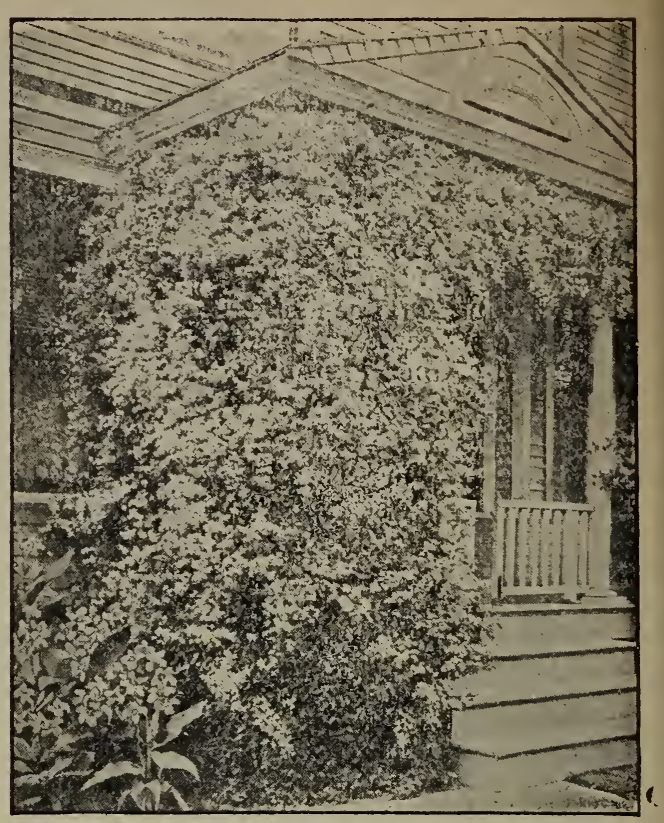

CLEMATIS PANICULATA

Ramona-Said to be an American seedling of the Jackmanni type, one of the strongest growers; flowers lav. ender blue, similar to the Gem.

Star of India-A very showy, very free flowering sort, with large flowers; first of a reddish plum color, chang. ing to a violet purple, with turkey red bar in the center of each flower leaf. A distinct variety of great merit. July to October.

\section{BULBOUS AND TUBEROUS R00TED PLANTS}

The ease with which bulbous-rooted plants are cultivated is no small thing in their favor. While seeds of annuals often fail to come up, or when, after growing, the plants die in transplanting, or are otherwise checked in their growth, and while bedding plants are frequently discouraged by the change from the hot house to the border-while shrubs require frequent pruning, trimming and constant watching and training to keep them in proper condition for blooming, a bulb only requires to be put in the ground at the proper time and place, and it will afterwards take care of itself, abundantly rewarding the grower for affording it an opportunity to become "a thing of beauty," and consequently "a joy forever."

Early in the spring, usually by March 1st, we see the Snow Drop and Crocus forcing themselves through the still frozen ground. These are followed in quick succession by Crown Imperials, Hyacinths and Tulips, all of which will be in flower long before it is generally considered time to " "make garden." As there is not a week through the season that there is not the natural flowering time for some of this class of plants, a bed planted with them alone would never be out of bloom from early spring till the autumnal frosts, and with a little attention at the time of planting, a succession of the most gorgeous flowers can be had through the entire season. 
FOR FALI PLANTING

Anemones, Colchicum, Spring and Autumnal flowering. Crocus, named or mixed. Crown Imperials. Iris, (Fleur de Lis). Jonquils-(See Bulbs for spring planting). Ranunclus. Snow Drops.-Double and Single.

FOR SPRING PLANTING

Caladium Esculentum. Dahlias. Day Lily (Funkia. Gladiolus. Lily, Auratum(Gold Banded Lily). Lancifolium Album-(White Japan.) Lancifolium Rubrum-(Red Japan). Lily, Iancifolium Roseum-(Rose Japan). Candidum -(Common White Lily). Lily of the Valley. Madeira Vine. Trigridi-(Tiger Flower). Tritoma-(Red Hot Poker). Tuberoses.

\section{PAEONIES}

A SPLENDID CLASS OF SHRUBS, flowering in all shades, from red and lilac to white, with blooms from four to eight inches in diameter. Many of them are very double and have a delicate and refreshing fragrance; they are easily cultivated and require but little protection.

\section{CLASS I-PAEONIA MOUNTAN-TREE PAEONIES}

Alba Plena-Double white, shaded with purple at the center.

Banksii-(Chinese Double Blush Paeony) - Very large, fragrant flowers; rosy blush with purple center. One of the finest.

Moutan-The parent species is a native of China. The varieties are hand- some flowering shrubs, attaining from six to eight feet in height, in about ten years, with proper care. The flowers are remarkably striking, of gorgeous colors, very numerous and enormous in size, often measuring from six to nine inches across, and appearing in May.

\section{CLASS II-CHINESE HERBACEOUS PAEONIES}

These are beautiful, showy, and easily cultivated plants, blooming from the beginning of May till the end of July. They should be placed in every garden. A selection will give a continuous bloom for three months. We offer the best sorts varying from pure white, pink, rose, dark red, purple and deep crimson.
Fringed Leaved Paeonies-(Paeony Tenuifolia, fl. pl.)-Foliage a bright lively green, in long thread-like filaments, giving it the appearance of fringe. Scarlet crimson; a choice variety; perfectly hardy.

\section{ANEMONE JAPONICA (Wind Flower)}

Red Flowering-A distinct and beautiful species; flowers $2 \frac{1}{2}$ inches in diameter, bright purplish rose, with golden yellow centers, borne in great profusion from September to Novem. ber. Height $21 / 2$ feet; habit neat and compact; very desirable and effective as a pot plant, and in lines or masses in beds or mixed borders.
White Flowering-A distinct and beautiful variety of the preceding; flowers $21 / 2$ inches in diameter, pure white, center golden yellow, borne in great profusion from September to Novem. ber.

Whirlwind, Double White Flowering$\mathrm{New}$ and beautiful, with ragged edges.

\section{CANNA, CROCUS, DAHLIAS, ETC.}

CANNA.

Stately and highly ornamental plants, for both flowers and foliage. They attain a height of 2 to 5 feet, and may be grown single or in masses. Leaves green or brownish red; flowers scarlet, crimson, yellow, cream, etc., variously marked.

CROCUS-A universal favorite and one of the earliest garden ornaments; should be planted about two inches deep. Color, blue, white, yellow and striped.

DAHLIAS-There is nothing that, with the same amount of money invested, will give more show of flowers than Dahlias. We offer dry bulbs or tubers.
GLADIOLUS-The Gladiolus is the most attractive of all the summer flowering bulbs, and deserves a place in every garden, as it is sure to flower and do well with very little care. Set the bulbs from 6 to 9 inches apart, and about 4 inches deep. Plant from middle of March to first of June.

\section{HYACINTHS.}

The most beautiful and fragrant of early spring flowering bulbs, much used for winter forcing. 
IRIS (German).

The true "Fleur de Lis," the na. tional flower of France. They are perfectly hardy. Plants well established produce from 50 to 100 spikes of bloom, deliciously fragrant and fine for cutting. In beauty the flowers rival the finest Orchids.

Kaemferii (Japan).

Finest of all the Iris family. The flowers are of immense size, from 6 to 8 inches in diameter, and of the most beautiful and delicate shades. They are perfectly hardy, and flower in great profusion during June and July. The Iris thrives best if planted in moist soil.

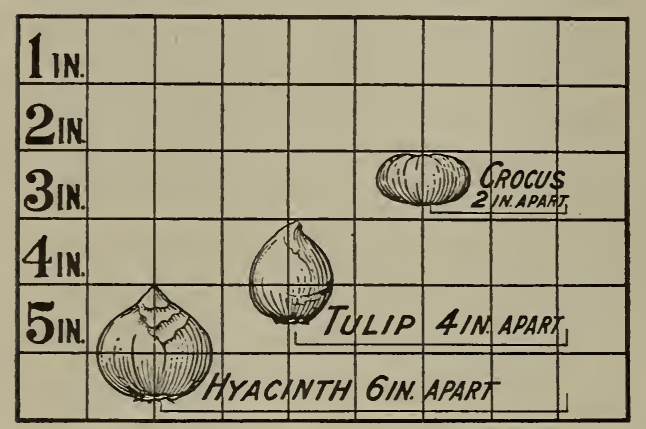

JONQUILS (Narcissus Jonquils).

Pretty varieties of the Narcissus, having a very agreeable fragrance; adapted to either pots or outdoor culture. The bulbs being small, six or eight may be put in a 6-inch pot.

\section{IIIY-OF-THE-VALIEY.}

This is as hardy as any plant can possibly be, and when planted in the open ground will increase rapidly. We can ship either in the spring or autumn.

TULIPS-Without these bulbs, for one or two months of beautiful spring weather, our gardens would present a bare appearance. We know of nothing that for the money invested will give a more gorgeous show during early spring and there is nothing more easily grow than the Tulip. Should be planted in October or November.

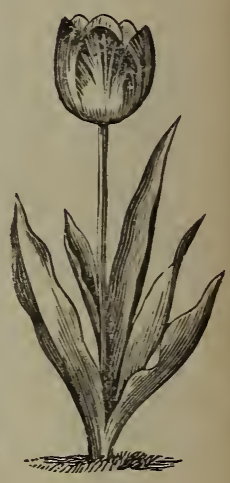

IIIIES (Iilium)

No class of plants capable of being cultivated out of doors possesses so many charms; rich and varied in color, stately and handsome in habit, profuse in variety, and of delicious fragrance. They thrive best in dry, rich soil, where water will not stand in winter. After planting they require very little care, and should not be disturbed for several years. Established plants bloom more freely than if taken up annually.

Auratum-(Gold Banded Lily of Japan) -Flowers very large, of a delicate ivory white color, thickly dotted with rich chocolate crimson spots, with a bright golden band through the center of each petal. The finest of all lilies.

Candidum-The old-fashioned pure white garden lily. One of the hardiest.

Farrisi-('The Bermuda Easter Lily)Flowers large, trumpet shaped, pure waxy white, gracefully formed and delightfully fragrant. The ease with which it can be forced into flower in winter has made it wonderfully popular as a winter flower.
Iongiflorum-A well known and beautiful variety, with snow-white trumpetshaped' flowers that are very fragrant, quite hardy and blooms freely in the open ground in June and July.

Tiger Lily-Bright orange scarlet with dark spots; a strong growing, showy variety, and entirely hardy. Suc. ceeds well everywhere.

Speciosum Rubrum-White, beautifully spotted red; flowers in August. One of the most useful of the Lily family, hardy and flowering well under all circumstances.

Speciosum Album-Very fragrant large flowers, pure white with a green running through the center of each petal.

\section{HEDGE PLANTS}

Hedges are valuable as a defense against animals, as wind-breaks, to protect orchards, gardens or farms unduly exposed, and as ornamental fences or screens to mark the baundaries of a lawn or cemetery lot.

\section{DIRECTIONS FOR SETTING}

Evergreens must be handled with care, so as not to allow the roots to become dried by the wind. Plants for hedges should be placed about twelve inches apart; larger sized plants will require more space.

California Privet, Honey Locust, and Osage Orange are generally planted in double rows about nine inches apart.

Other deciduous shrubs for hedges should be planted about twelve inches apart. 
DEFENSE AND ORNAMENT HEDGES

Buckthorn-(Rhamus)-One of the most popular and effective plants. A fine, robust grower, of European origin, with dark green foliage, white flowers and small black fruit in fall.

Honey Locust-For turning cattle and as a farm hedge, is much the best in the Northern States. It is of vigorous growth, perfectly hardy, thrives with ordinary care and is sufficiently thorny to be impenetrable.

Osage Orange-In the South and Southwest is in great favor.
Quince, Japan-See description, page 61. HEDGE FOR WIND-BREAKS

Norway Spruce is the best. Its vigorous habit, rapid dense growth, when properly sheared or pruned, large size and entire hardiness, are characteristics not easily obtained in any other evergreen.

American Arbor Vitae comes next. Belts of pine are also useful as a protection.

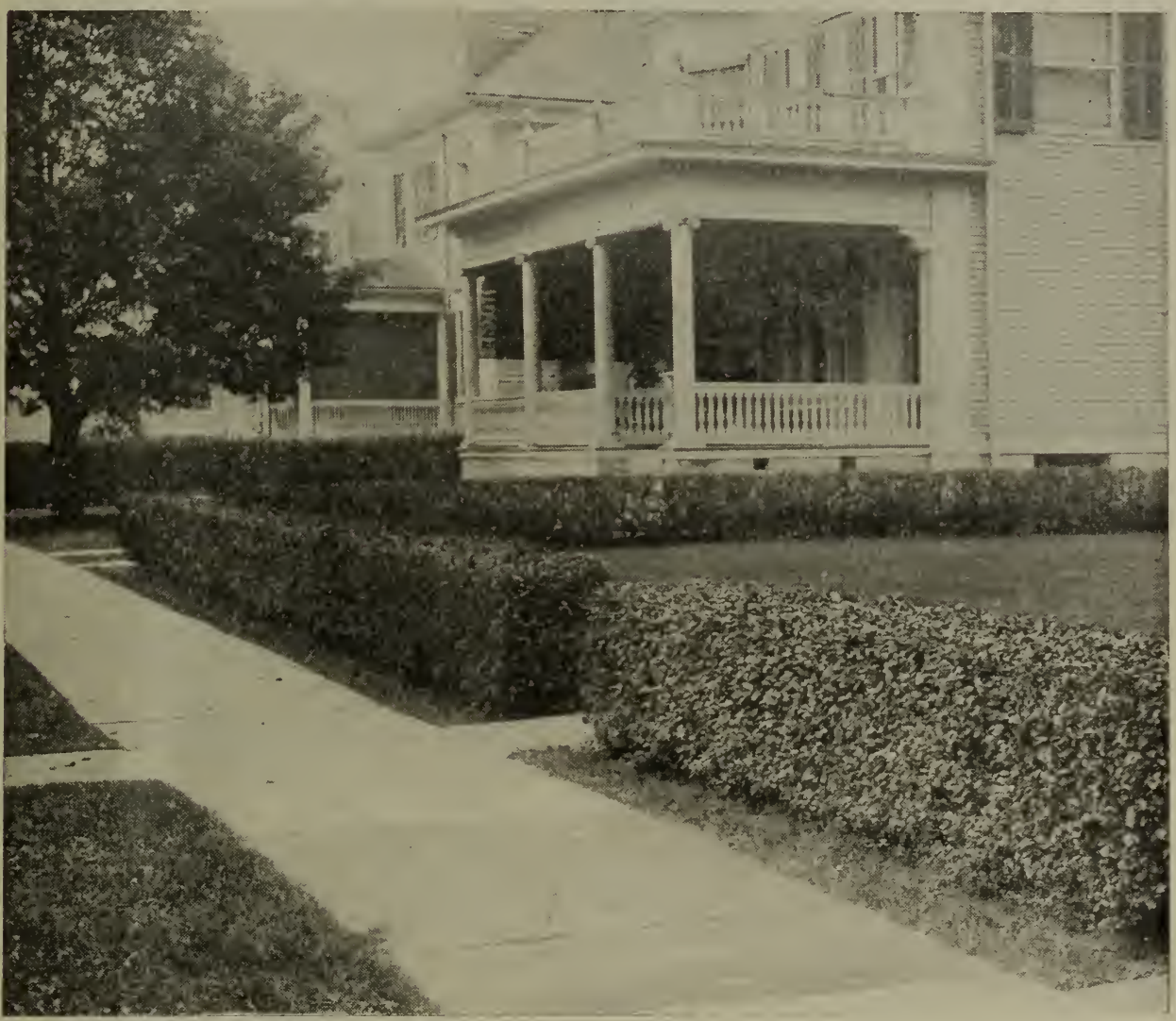

CALIFORNIA PRIVET

American and Siberian Arbor Vitae, Norway Spruce, and especially Japan Quince and Purple Barberry, all described in their appropriate places in this Catalogue, make be a u if u l screens or hedges.

The Crimson Rambler Hedge-This rose is such a strong, rampant rapid grower that it soon makes a most desirable hedge or screen for a fence. Trained along a wire fence and planted three to four feet apart, they form a perfect screen and when in full bloom with its thousands of miniature crimson roses in clusters makes a truly magnificent sight.
Privet, California-This well-known hedge is probably used more extensively than any other variety. In fact our plantings each season exceed that of any other ten varieties. In many towns and cities the Privet is used more than all other varieties of plants or evergreens put together. In this state the leaves do not usually drop before the middle of January, hence it is almost evergreen. 


\section{BORDER PLANTS}

We offer a fine assortment of the best varieties of these useful plants, which are exceedingly valuable on account of their hardiness, easy culture and showy appearance. They will mostly live all winter in the open ground and bloom freely every vear. We name our leading sorts.

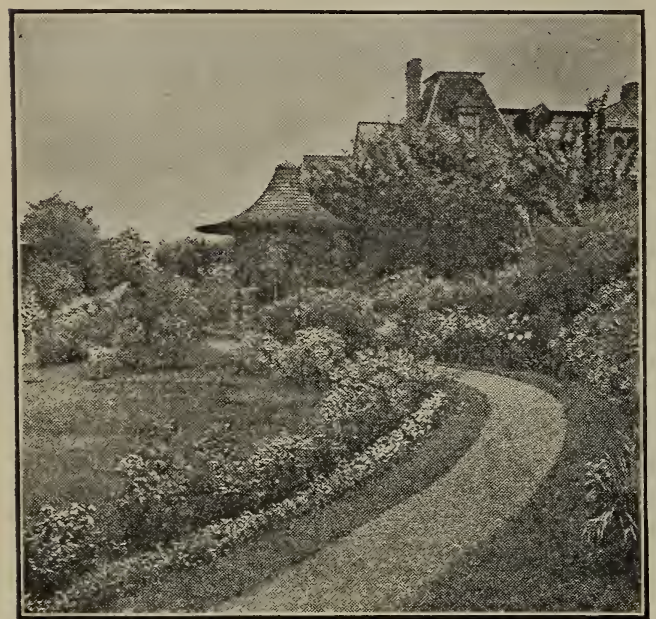

Anchusa Italica-(Heavenly Blue Flower)-Dropmore variety-true - The most important Blue Flowered Hardy Border Plant we have. It is a strong, vigorous plant of branching habit and perfectly hardy. July and August.

Dielytra-(Bleeding Heart)--Rosy, heartshaped flowers hanging in great profusion from a gracefully curved stem. May and June.

Fox-Glove-(Digitalis).

Long bell shaped flowers on stems three to four feet high; white and red; very showy. July to September.

Gaillardia Grandiflora-(Blanket Flower)

Flowers large, brightly colored and of perfect form.

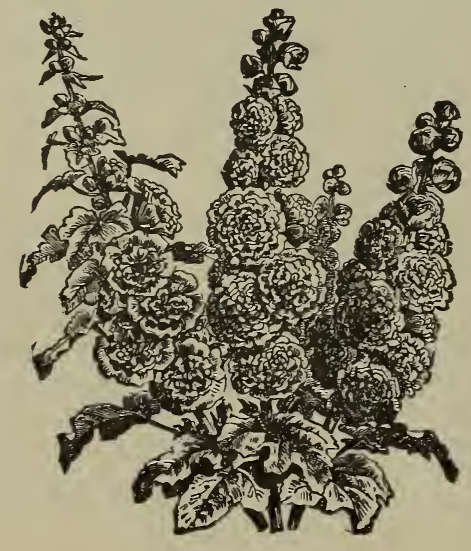

HOLLYHOCKS

Hollyhocks-A fine collection of colors.
Larkspur-(Delphinum).

Flowers in terminal spikes in brilliant blue, purple, white or red. June to August.

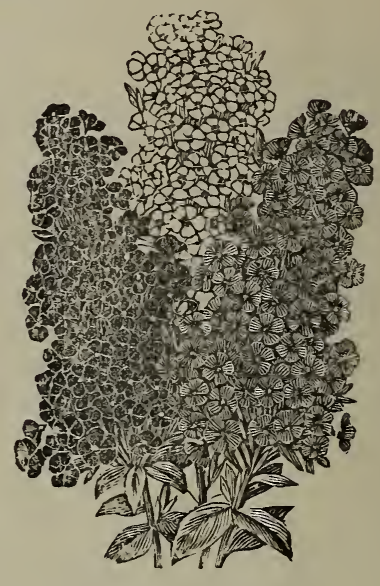

Phlox.

\section{LARKSPUR}

The Phlox is one of the most interesting of all our herbaceous perennial plants, and commends itself to everyone.

Veronica Longifolia Subsessilis.

The handsomest hardy border-plant. Color of flowers, a lovely amethystine blue. It is a superb hardy perennial, growing to the height of two feet, flowering persistently in summer and late fall. It succeeds in any soil.

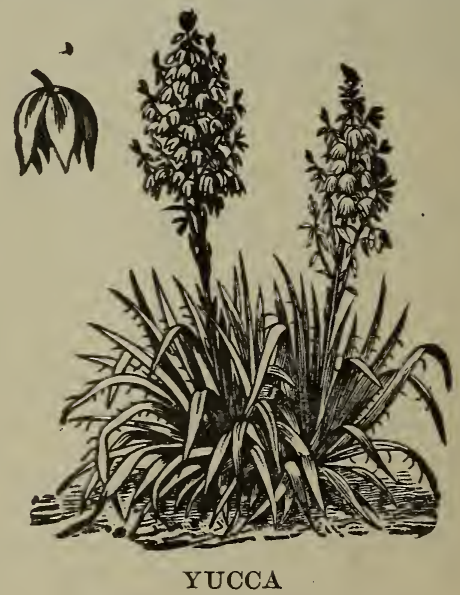

Yucca-(Adam's Needle).

Handsome evergreen plants, with long, narrow, palm-like leaves, and tall upright stems, bearing showy, creamlike flowers. July. 


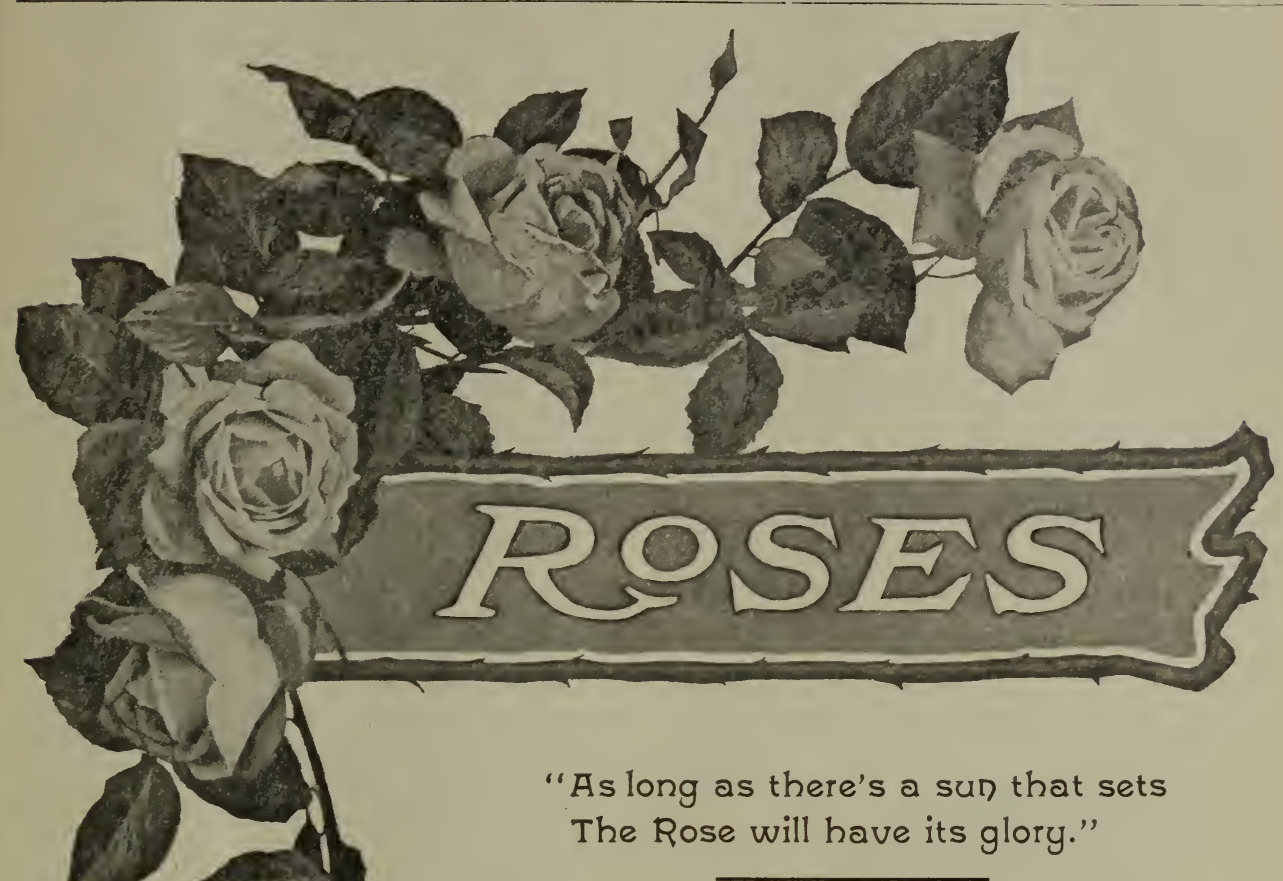

WE are constantly adding the most promising new kinds to our list,

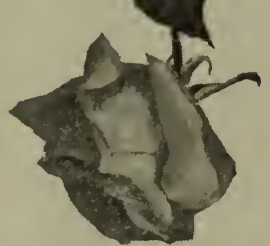
and have one of the best grown and best selected stocks of Roses in the country.

Cultivation-Roses require plenty of manure and good cultivation. Old and decayed branches and at least half the previous season's growth should be cut away early each spring, and a little cutting back after the first blooming will insure more late flowers. The so-called tender Roses must be carefully protected in winter by covering them with leaves and evergreen boughs; and the hardy sorts will be rendered more vigorous and productive of fine flowers, if they, too, are similarly protected.

Insects-See page 82.

Our Roses are strong plants grown out of doors, well rooted and every way desirable. They have already bloomed before being sent out, and are in every respect much better and stronger plants than the ones that are so fully advertised and sent out by mail, which are small, tender shoots, started in a greenhouse, and after a few weeks sent out before they have established growth and constitution enough to stand the shock of transpianting.

\section{CLASS A-HARDY PERPETUAL OR REMONTANT ROSES}

In this class are included the so-called "Hybrid Noisette," also a few of the "Hybrid Teas." These two groups contain some very beautiful varieties which cannot be omitted from any good list of Roses for outdoor cultivation, but as they are much more tender than any other in this class, they must be thoroughly protected in winter by a covering of forest leaves or other light litter. We also include Summer Roses (Hybrid China and others), blooming but once in the season, but very hardy and beautiful. As for the rest of this class, it comprises many of the most beautiful Roses in cultivation, and as they are hardy and easy of culture, they must be, as a class the most popular and reliable for the multitude of planters. To insure their blooming freely in the autumn, however, they must be cut back in the summer, and a portion of the first crop of flowers sacrificed.

The most of our Roses are propagated on their own roots from cuttings. They are never liable to throw up suckers of an inferior kind. 
Alfred Colomb-Brilliant carmine crim. son, very large, full, of fine globular form and extremely fragrant.

Anne de Diesbach-One of the best and most satisfactory Hybrid Perpetual Roses. A strong, vigorous grower, extremely hardy, producing very large, double flowers, of a lovely shade of carmine and delightfully fragrant.

American Beauty-Large, globular; deep pink, shaded with carmine; delicious odor; has proved to be a most delightful variety for forcing and may be found valuable for cultivation out of doors.

Augusta Mie-Delicate pink, finely cupped. A vigorous grower.

Baron de Bonstetten-Rich, velvety, maroon; large, full. A splendid sort.

Black Prince-Dark velvety crimson, almost black. A good grower and most magnificent rose.

Bessie Brown-This is a noble rose of extra fine quality and bears large full flowers of extraordinary depth and fullness and is deliciously sweet; color, pure white, clouded and flushed with flesh pink.

Caprice-A true hybrid perpetual, perfectly hardy; a strong grower, a great bloomer. It has attracted a great deal of attention both on the Pacific Coast and the East. Valued chiefly as a novelty, being striped pink and white.

Caroline de Sansal-Clear delicate flesh color; fine form; a strong grower and one of the best of its color.

Caroline Marniesse-(Noisette)-Creamywhite, flowers small and full, and borne in very pretty clusters; an exceedingly free bloomer; low growing (18 inches) and especially desirable for the border of a bed; entirely hardy.

Clio-A rose of remarkable beauty. On the style of Baron Rothschild, having like it, large handsome flowers, of fine globular form, which are produced in great abundance. Color a delicate flesh, shaded in center with rosy pink. A magnificent rose in every particular.

Conrad F. Meyer-Splendid, large, elegantly formed buds and flow. ers, $3 \frac{1}{2}$ to 4 inches across and perfectly double-color, r i c h peachy yellow, delicately tinged with silver rose; very fragrant, entirely hardy and valuable in every way.

Coquette des Alps-White, slightly shaded with carmine; form semicupped; wood long jointed; large handsome flowers. The strongest grower of the entire class.
Coquette des Blanches-Pure white, somewhat flat, but full and very pretty; growth more bushy and symmetrical than any of the others; one of the hardiest.

Dinsmore-Scarlet crimson, large, double, very fragrant; free bloomer; one of the finest roses.

Duchess of Albany-Vivid crimson; flowers expand, and developing a beautiful shade; autumnal bloomer. Budded plants.

Duke of Edinburgh-Bright crimson, large, double flowers, slightly fragrant. Foliage large and attractive. A free bloomer early in the season.

Earl of Dufferin-One of the finest roses of recent years; red and velvety crimson, shaded with dark maroon. Large flower, finely formed, vigorous grower. One of the very finest dark roses and should be in every garden.

Etoile de Lyon-(Star of Lyons)-The best pure deep yellow rose for garden planting, hardy and beautiful.

Etoile de France-(Star of France)-One of the most magnificent new roses introduced in the past few years. It is a strong healthy grower, quite hardy and a quick and abundant bloomer, makes beautiful la r g e pointed buds and extra large fully double flowers, three and one-half to four and one-half inches across. Color, intense brilliant crimson, very fragrant.

Frau Karl Druschki or (Snow Queen)It is perfectly hardy everywhere and a most vigorous grower, throwing up enormous shoots which are covered with snow white blossoms. Although we have many so-called white roses, it is a fact that before the introduc.

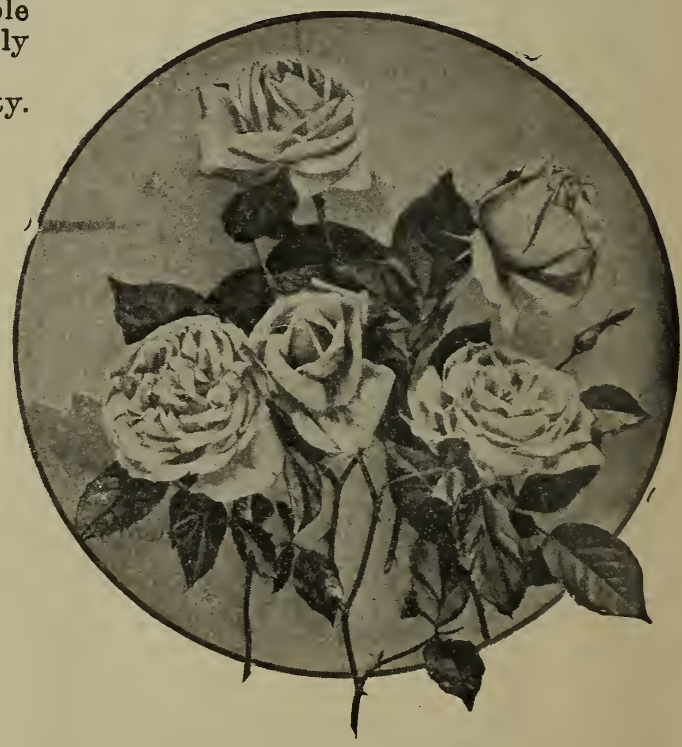

FRAU KARL DRUSCHKI 
tion of Frau Karl Druschki we have not had a pure snow-white hardy rose. Heretofore the white roses have been tinged with pale pink or cream color. A grand rose sure to be in great demand.

Fisher Holmes-One of the choicest of perpetual roses. Bush is vigorous and produces freely of superb blossoms. Color brilliant carmine crimson.

Francois Levet-Cherry $r$ ed; medium size; well formed; one of the Paul Verdier style; very free bloomer and vigorous grower.

General Jacqueminot-Brilliant crimson, large and very fine; one of the handsomest and most showy roses of this color. Beautiful in the bud, semidouble when full grown. Of fine free growth; a universal favorite.

General Washington-Fine crimson; very full and double; a moderate grower; one of the handsomest roses when well grown.

Glorie de Margottin-New. This is the brightest colored rose yet introduced and is in every way a most desirable variety, being a good, strong, vigorous grower and free bloomer; good for either forcing or outdoor culture.

Golden Gate-A rose of surprising beauty, extra large, very double and full also delightfully fragrant. $\mathrm{R}$ i c h creamy white; beautifully tinged with golden yellow and bordered with clear rose, a constant bloomer, extra fine.

Gruss an Teplitz-(Virginia R. Cox, or Crimson Hermosa)-This grand rose has proved one of the best and most valuable hardy crimson ever-bloom. ing roses for garden planting ever introduced. The color is dark rich crimson passing to velvety fiery red, one of the very brightest colored roses we know. Flowers large, full and sweet; very showy and handsome; blooms constantly, throwing up fresh buds and flowers the whole growing season. It is a healthy vigorous grower, entirely hardy here. Cannot be recommended too highly; everyone should have it.

Helen Gould-The most satisfactory rose of its color for general planting ever introduced. Better than American Beauty. Beautiful long-pointed buds, and immense, full and perfectly double flowers. Color warm, rosy crimson.

Her Majesty-A remarkably strong-growing variety, often throwing up shoots six feet in length; the flowers are of unusual size, specimens having been exhibited that were fully six inches across. Color a beautiful, clear, satiny pink.
Helen Keller-Flowers large, of most perfect form and fragrant. Color brilliant rosy cerise. A vigorous grower and very free bloomer. A most distinct and lovely rose.

J. B. Clark-A strong and upright grower. Exceedingly vigorous. Very fragrant. A genuine treat is in store for every. one who plants it.

John Hopper-A seedling from Jules Margottin; fertilized by Mme. Vidot. Bright rose with carmine center; large and full; light red thorns, not numerous; a profuse bloomer and standard sort.

John Keynes-A strong grower and as hardy as any of the perpetual fam. ily. Flowers very large and fine; brilliant carmine. A splendid rose.

Jubilee-Flowers very large; color described as intense crimson, maroon red; fragrant, strong and lasting. Plant very vigatous; large, dark green foliage.

Jules Margottin-Bright cherry-red; large and full; free flowering and hardy.

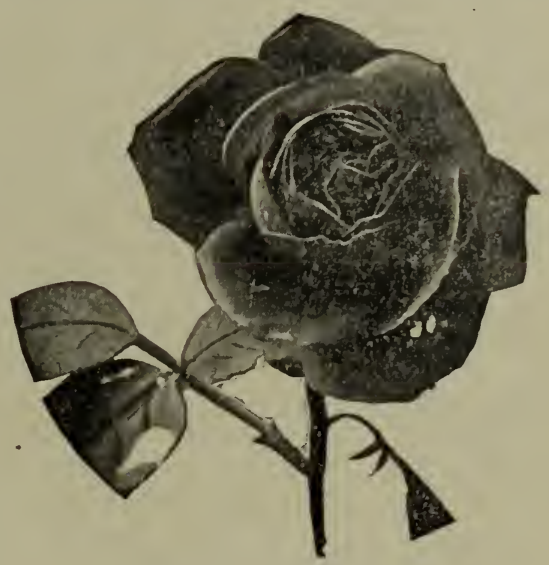

GRUSS AN TEPLITZ

Killarney-The best hardy garden rose. The color is an exquisite soft pink, of fine satin texture, with a rare and delightful fragrance. The buds are remarkably beautiful. The more they expand the richer and more beautiful becomes the color. It flowers continually from June until November. It is perfectly hardy and will stand our severest winters.

La France-Delicate silvery rose; very large and full; an almost constant bloomer; equal in delicacy to a Tea Rose; the most pleasing fragrance of all roses; only a moderate grower, but most desirable.

La Reine-Brilliant, glossy rose, very large, cupped and beautiful; a very hardy useful rose.

Iady Helen Stewart-Another beautiful and valuable variety. Bright crimson, scarlet; large, full and of perfect form; highly perfumed. 
Liberty-Deep bright crimson scarlet, one of the richest colored roses we have; beautiful buds and large full flowers, very fragrant; a constant bloomer; fine for house culture and cut flowers.

Louis Van Houtte-Crimson, maroon, medium size, sometimes large, full. A tender sort, but very free blooming and altogether the best crimson rose we have. A moderate grower.

Lord Penzance-(Sweet Brier)-Foliage sweetly scented; strong grower, perfectly hardv. Colors in variety.

Mme. Charles Wood-Bright rich cherry red; earlv; profuse bloomer.

Margaret Dickson-Of magnificent form, white with pale flesh center; petals very large, shell shaped, and of great substance; foliage very large, dark green.

Mabel Morrison-A sport from Baroness Rothschild. Flesh white, changing to pure white; in the autumn tinged with rose; double cup-shaped flowers, freely produced. It is one of the best white hybrid perpetuals.

Madam Gabriel Iuizet-For loveliness in color, fragrance, size and freedom of blooming qualities, this rose has no equal to-day; equally good as a bedding rose out doors. Pink, distinct, very large, cup-shaped, somewhat fragrant. As an exhibition rose will rank with its rival, Baroness Rothschild.

Madam Plantier-Pure white, medium size, full; flowers produced in great abundance early in the season.

Mad. F. Kruger-Named after the wife of Com Paul Kruger, President of the late South Africa Republic. Fine large buds and flowers fully double and borne well up on strong, vigorous bushes; color soft rose nink, elegantly shaded with crimson and amber; very handsome and showy and delightfully sweet.

Mamam Cochet-Silvery pink; a most wonderfully beautiful French rose of great value. The beautiful, big, elongated buds and full blown double flowers are exquisitely charming, while the fragrance is rich and delicious. The color is fleshy pink, with the inner side of petals silvery rose. Grows vigorously and blooms with great freedom.

Marie Bauman-Brilliant carmine crimson; large, full, of exquisite color and form; very fragrant, extra fine. Budded plants.

Marchioness of Dufferin-A new rose which has attained much popularity. It is of enormous size; beautiful rosy pink, suffused with vellow at the base of petals; a very strong rapid grower; considered one of the finest.
Marie Rady-Vermillion, shaded with crimson; large, very full, of fine glo. bular form. A fragrant, superb sort.

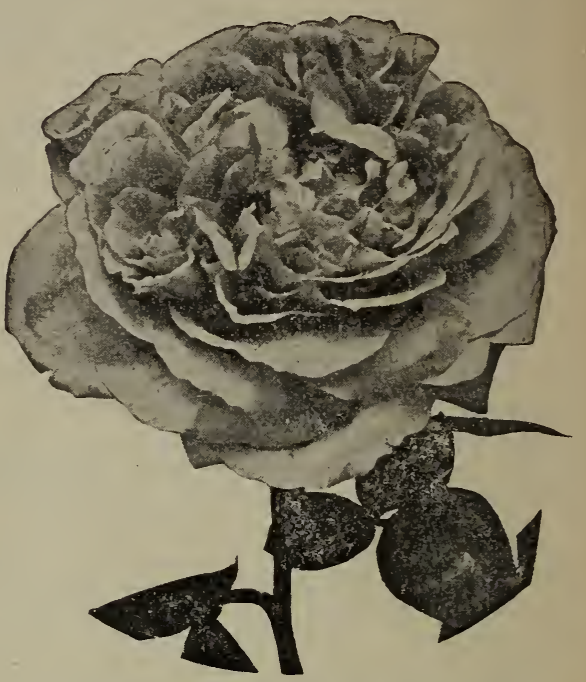

MARCHIONESS OF LONDONDERRY

IViarchioness of Londonderry - I v o r y white, fine form, highly perfumed; plants vigorous and free flowering. Unquestionably one of the largest roses, blooms attaining a diameter of six inches when fully developed, and one of the sweetest of the Hybrid Perpetuals.

Magna Charta-Bright pink, suffused with carmine; very large, full and fragrant with magnificent foliage. A free bloomer. For the earliest deep color is still the best.

Marshall P. Wilder-Raised from the seed of the General Jacqueminot. It is of vigorous growth, with healthy foliage; flowers large, semi-globular, full, well-formed; color cherry-carmine. In wood, foliage, form and flower, it resembles Alfred Colomb.

Mrs. John Laing-New. As a budding rose this is undoubtedly one of the best varieties yet introduced, being hardly ever out of bloom all summer. Color a beautiful shade of delicate pink; of large size and very fragrant. It is also a good forcer from January onwards.

Mrs. R. G. Sherman Crawford-Color deep rosy pink, outer petals shaded with pale flesh, white at base of petals; flowers large, of perfect inbricated form and freely produced, flowering from early summer until late in autumn. Growth vigorous. Awarded gold medal of the National Rose Society of England and many first-class certificates. A valuable addition. 
Merveille de Lyon-Pure white, shaded and marked with satin; flowers very large, double and of beautiful cup shape. A seedling from Baroness Rothschild. A superb variety.

Meteor-As a dark crimson perpetual blooming rose, this ranks as one of the best yet introduced of any class. It is especially valuable for summer and fall, blooming either in the greenhouse or in open ground, and where there is a demand for fine roses in summer this variety will become a great favorite.

Madam George Bruant - (White) - A seedling from the Japan Rose-Rosa Rugosa and Tea Rose-Sombrieul. From these it gets exquisite sweetness and its everblooming character. Considered by the best judges to be of great value.

My Maryland-Growth robust and very free flowering; flowers medium size, full; color bright salmon pink with paler edges; delightfully fragrant. Promises to be one of the most popular varieties in this country.

Paul Neyron-This magnificent rose, by far the largest variety in cultivation; very double and full, of beautiful deep rose color, and deligbtfully fragrant; borne upon vigorous, upright shoots in great abundance throughout the entire season. IVe recommend this variety very highly for general planting as it is calculated to give more satisfaction to the masses than any other known variety.

Persian Yellow-Deep, bright yellow; small but handsome; double; a very early bloomer, and much the finest hardy yellow rose.

Plerre Notting-Blackish-red, shaded with velvet; globular form, very large and full, and one of the finest dark roses. Needs some winter protection.

Pius IX.-Deep rose, tinged with carmine, large and full; a robust grower and profuse bloomer.

Prince Camille de Rohan-Deep, velvety crimson, large, moderately full. One of the darkest in cultivation and a splendid rose.

Rhea Reid-This is the best Rose introduced in 1908. It is a rich red, very double, fine form and a constant bloonier.

Soliel D'Or-(Golden Sun)-New. Mardy yellow rose; foliage glossy. Robust in growth and is sure to be popular.

Bunrise-This is one of the most beautiful everblooming Roses in cultivation; the flowers are extra large, perfectly double and delightfully tea-scented. Dark peachy red, ele- gantly shaded with orange and crimson-like the Sunrise tints seen in the summer sky-a strong, healthy grower and free bloomer.

Sunset-The new orange yellow Rose; ground color deep orange yellow, thickly shaded with dark ruddy crimson; beautiful buds and large full flowers, deliciously tea-scented. A strong, healthy grower and abundant bloomer.

Ulrich Brunner-A superb rose; a seedling from Paul Neyron; extra large, bold flowers; full and globular; petal large and of good substance; color rich, glowing crimson, e le ga n t ly lighted with scarlet; fragrant.

Victor Verdier-Fine, bright rose, shaded with carmine; very hardy and a fine bloomer; a splendid rose.

\section{ROSA RUGOSA}

This is a very interesting group, of Japanese origin. The flowers are mostly single. The plant is highly ornamental on account of its good.habit and beautiful glossy foliage.

Rugosa Alba-A species from Japan. Single, pure white flowers of five petals; highly scented; a splendid shrub.

Rugosa Rubra-Another Japan variety. Flowers single, of a most beautiful bright rosy crimson, succeeled by large berries of a rich rosy red color, and are a great addition to the ornamental character of the plant. Makes a beautiful low hedge.

\section{HARDY CLIMBING ROSES}

Baltimore Belle-Pale blush, nearly white; double; the best white climb. ing rose.

Blue Rambler-(Veilchenblau) - Violet Blue. Hailed by the German rose growers as the forerunner of a gen. uine cornflower blue rose. It is a seedling of Crimson Rambler. The blossoms massed in large umbels, are semi-double, of medium size. The color, on first unfolling, is either reddish pink or purplish pink then turns amethyst, and finally steel blue as the flower fades.

Crimson Rambler-(Climbing Polyantha) -A wonderful rose from Japan, bearing immense trusses of deep crimson flowers, which hold their beautiful color a long time without fading. It is a very vigorous grower and thus makes a splendid climbing rose, though it may also be grown in bush or villar form. When in full bloom and covered as it is with its great trusses of flowers, containing thirty to fifty blossoms each, it is 


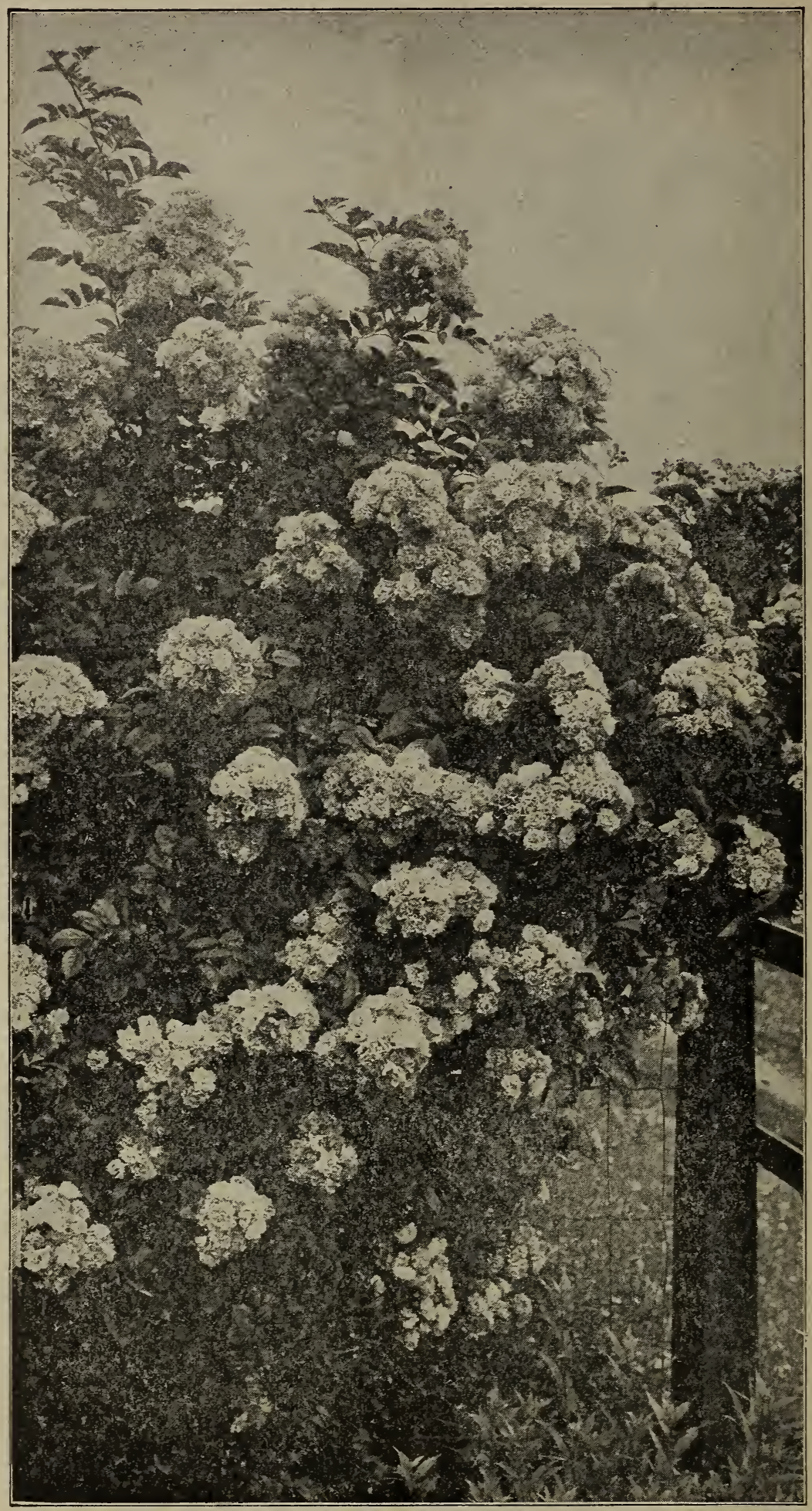


a most magnificent sight. It has proved entirely hardy in this country, and is a very great acquisition to our rose garden.

Climbing Jules Margottin-Carmine rose, fine in open flower and in bud; the best of all climbing sorts. It may be grown either as a pillar Rose or by pruning, kept in bush form, it should be in every collection.

Climbing Meteor-(Red)-One of the finest bright crimson hardy Everblooming Climbing Roses ever introduced; makes exquisite buds and large beautifully shaped flowers of the true Jacqueminot color.

Dorothy Perkins-A Hybrid of Rosa Wichuraiana and Mme. G a b riel Luizet. In its foliage, growth, and habit of blooming, it is remarkably like Crimson Rambler, but the flowers are more double and of a beautiful shell-pink color, and hold a long time without fading. The flowers are also very sweetly scented, a characteristic not possessed by most other Roses of the Rambler family.

Empress of China-A perpetual blooming climber. The color is a dark red in the bud, and changes as the flower opens and grows older to a lighter red or pink.

Flower of Fairfield-(The Everblooming Crimson Rambler)-For many years it has been the aim of every Rose grower to raise a Rambler that would be ever-blooming, and now we are able to offer such a rose. This new variety is a sport from the famous and beautiful Crimson Ram. bler, similar in color but more brilliant and more lasting than the old favorite. It possesses a further advantage over any other Rambler in the fact that it flowers profusely on the young wood in its first year. The new "Flower of Fairfield" is of vigorous growth, and when in bloom supersedes anything else by the wonderful display of its brilliant crimson clusters of blossoms. It starts blooming in the early spring, and continues to flower till late in autumn, thus it is rightly termed "Perpetual Blooming." "This new climber is not only most effective for covering walls or trellises, arches, etc., but most attractive for table decorations and other cut purposes.

Gem of the Prairie-Cermine crimson occasionally blotched with white; a cross hybrid between Madam Laffay and Queen of the Prairie.
Greville, or Seven Sisters-Crimson, changes to blush; flowers in large clusters.

Lady Gay-This Rose is superior to Crimson Rambler of which it is a seedling and which it closely resembles in habit of bloom and vigor of growth. The flowers (in large, loose clusters) are of a delicate cherry pink color, fading to soft tinted white. The effect of a plant in full bloom with the combination of soft white flowers, cherry pink buds and deep green of the foliage is indeed charming. It is perfectly hardy and unsurpassed for climbing work.

Mary Washington-One of the hardiest of ever-blooming climbers, a remarkably free bloomer, producing medium-sized pure white flowers in large clusters. An extra strong grower when established.

Philadelphia Rambler-An improvement on the famous Crimson Rambler, flowers being larger, much more double, and of a lighter crimson color.

Pink Rambler-Flowers medium size, pink in clusters. Very pretty.

Queen of the Prairio-Bright rosy red, frequently striped with white; large, compact and globular.

Tausendschon-(Thousand Beauties) New. Imagine a luxuriant climbing rose literally covered with thousands of bright blossoms, borne in clusters and quite double. Colors of every imaginable shade, from white to deep pink. A hardy vigorous grower with few thorns and handsome foliage.

Victor Verdier Climbing-Resembles Victor Verdier, of which it is a seedling, but having a decided climbing habit. This variety is particularly desirable on account of its vigorous constitution and free flowering habit.

White Rambler-Similar in origin, habit of bush and bloom to Crimson Ram. bler, but not so strong a grower.

Wichuriana-(Memorial Rose) - Charming trailer from Japan; produces numerous clusters of white fragrant flowers in July. Very hardy and vigorous. Valuable as a covering for banks, rockeries, otc., and for use in cemeteries.

Yellow Rambler-(Aglaia) - The hardiest yellow climbing rose yet introduced. Very fragrant and very vigorous grower; a worthy companion to the wonderful Crimson Rambler. 


\section{DWARF PERPETUAL RAMBLERS \\ Ideal Bedding Roses}

Baby Rambler (Red) -This new Rose is a cross between Crimson $\mathrm{R}$ a $\mathrm{mble} \mathrm{r}$ and Glory of Polyanthus, and may be described as a dwarf form of the widely known and popular climbing rose, C r i m s on Rambler, being har$\mathrm{dy}$, vigorous and perpetual flowering. The flowers are large, well formed, of a crimson red color and borne in clusters.

\section{Pixk Baby Rambler} -(Anny Muller) -This new Pink Baby Rambler is of the same free flowering Polyan-

tha class as the Crimson Baby Rambler. The blossoms are a fascinating shade of deep rose with petals curled and twisted, producing a fluffy effect. Its hardiness, vigorous habit of growth, with well branched bushes and healthy, rich green foliage, are all qualities which (just as in the case of the Crimson Baby Rambler) commend it to the careful buyer.

White Baby Rambler-(Schneewittchen or Snow)-One of the most charming Roses in the Polyantha class is this little rose. It continues to bloom all Summer through with amazing ireedom and fullness. Bushes candelabra shaped and each branch bearing from 15 to 50 little flowers, creamy-white passing to snow-white. A truly charming rose and affords an abundance of flowers for cutting.

MOSS ROSES.

This is a favorite class with everyone, on account of the beautiful buds, which, for bouquets and cut flowers, are invaluable.

Blanche Moreau-Pure white, large, full and of perfect form; the buds and flowers produced in clusters and freely furnished with a deep green moss. A valuable variety.

Blanche Robert-Flower pure white, large and full; buds very beautiful. A rampant grower.

Countess de Murinais-Pure white, large, very desirable; th? finest white

Crested-Deep pink buds, surrounded with mossy fringe and crest; very beautiful and fragrant; growth slender.

Glory of Mosses-A moderate grower. Flowers very large, appear to best advantage when full; color pale rose.

Luxemburg-Deep c:imson; fine grower.

Princess Adelaide-A vigorous grower, pale rose, of medium size and good form.

Perpetual White-Pure white.

Salet-A vigorous grower and perpetual blooner. Light rose, large, full. The best of the class. A true perpetual moss, blooming at intervals from June to November.

White Bath-White, sometimes tinged with flesh; attractive in bud and open flower. This is by far the best white moss.

PERPETUAI TENDER ROSES.

Under this head we include all cl.sses of Tender Roses-Bourbon, China, Noisette and Tea, and indicate the class to which each variety belongs with the letter $\mathrm{B}, \mathrm{C}, \mathrm{N}$, or $\mathrm{T}$, respectively.

Agrippina- (C)-Red, velvety crimson; moderately double; fine in buds; valuable for planting out. One of the best.

Bon Silene-(T)-Rosy carmine, shaded with salmon; fragrant and very free flowering. Valuable for the buds. 


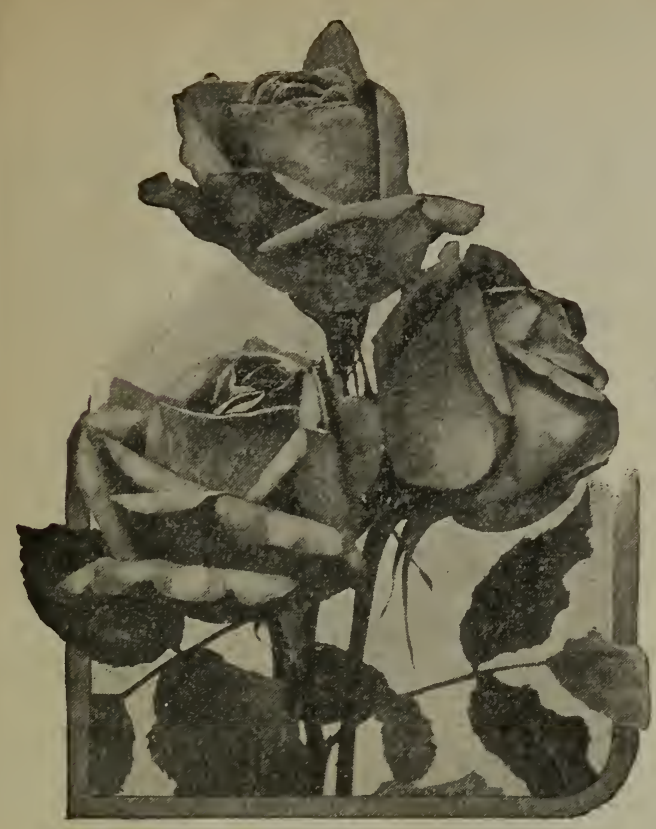

RICHMOND

Bride-(T) - A lovely pure white Tea Rose of large size. Admirable for forcing as well as for summer flowering. The buds have more substance than Niphetos, are full and double, and possess the good characteristics of Catherine Mermet.

Bridesmaid-An exquisite rose, both in bud and open flower; bright, clear pink, large and very double, stems long and stiff; foliage handsome and glossy. Excellent for both summer and winter flowering.

Catherine Mermet-(T)-Brig h t flesh color, with the same peculiar lustre possessed by La France. Large, full and beautiful. One of the finest Teas.

Cornelia Cook-(T)-Pale yellow is h white, tinged with flesh. A superb rose when well grown.

Glorie de Dijon-(T)- Climber. A combination of salmon, orange and buff; early; large, and of good globular form; hardy.

Hermosa-(B)-Bright rose; a most constant bloomer; hardy; one of the best.

Kaiserin Augusta Victoria-(T)-A superb rose, to which too much praise cannot be given. It is of soft pearly white, fragrant, a strong, healthy grower, with bold, beautiful foliage. Flowers borne in profusion, on long, graceful stems, every shoot being crowned with a magnificent flower.

Iyon-A splendid new Hybrid Tea direct from France. A rose of rare excellence. The form is full and globular with large broad petals of good texture. The flowers are romarkably rich in color, being a "shrimp pink at ends of the petals, center coral red or salmon pink shaded with chrome yellow." It is "very fragrant" and above all a "perpetual and incessant bloomer." At Lyons it received the "Prize of Honor with warmest congratulations of the judges." One of the best new roses.

Marechal Neil-(N)-Deep yellow; very large, very tull, globular, highly scented; requires careful treatment. It should be severely pruned. The finest yellow rose.

Mad. Caroline Testout-A very handsome rose. A profuse bloomer. Flowers large and of a pretty rose color.

Niphetos-(T) - Pale, yellowish-white, often snowy-white. Long, large buds. Very beautiful.

Papa Gontier- (T) - Rich cherry red, reverse of petal crimson; large, semidouble, fragrant, free flowering; very popular for winter forcing.

Perle des Jardins-( $T)-A$ b e a $u$ if $u l$ straw color, s 'metimes deep canary; very large, full, and of fine form; stiff shoots or stems, and very freo flowering.

Richmond-Last Winter during the Annual Convention of the American Rose Society in Washington, some 200 members called on President Taft and presented him with the finest bouquet from their Exhi. bition. It was a vase of Richmond Roses. It is a grand Rose for house culture and forcing, producing splendid buds and flowers on fine long stems. Bright glowing scarlet crimson, exceedingly bright and beautiful.

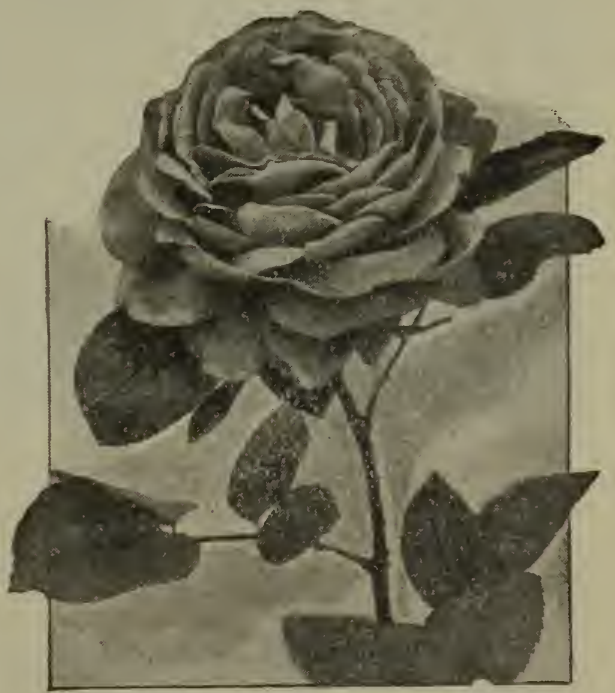

KAISERIN AUGUSTA VICTORLA 
safrano-(T)-Saffron and apricot. A very free bloomer. One of the oldest and best varieties, especially when used in the bud state.

Souvenir de la Malmaison-(B)-Pale flesh with a fawn shade; very large, showy, beautiful. An old favorite.

White Ia France-(Augustine Guinoissea)-Buds and flowers are extra large, very fus and finely formed, and delightfully perfumed. It blooms all through the season and is a rose that everyone will like to have.

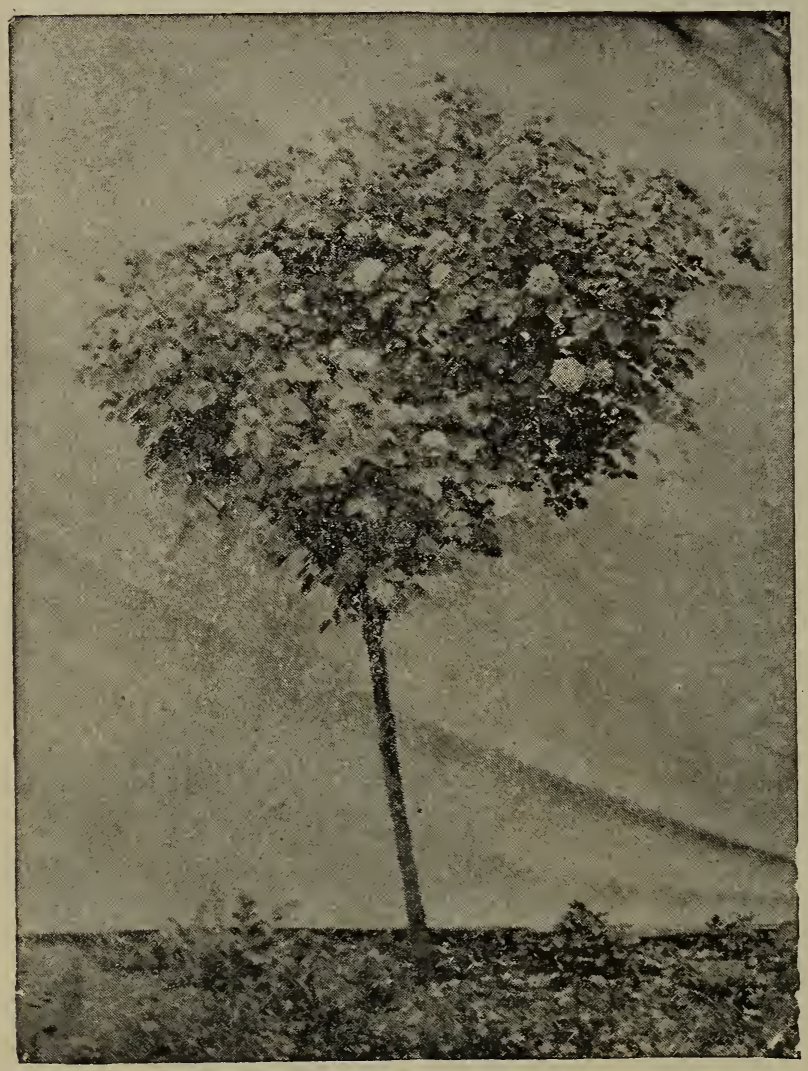

CRIMSON RAMBLER TREE ROSE
POLYANTHA ROSES.

This charming class is from Japan and of recent introduction. The foliage and flowers are very small, the latter being produced in clusters. They are of slender growth and produce extremely beautiful little flowers. They are quite as hardy as many well known varieties that are considered perfectly hardy. We offer four of the best.

Cecil Brunner-Salmon pink, deep scarlet center. Very small flower, delicately scented.

Clothilde Soupert-Medium sized, very double, produced in clusters; pearly white, with rose lake center, sometimes producing red and white flow. ers on same plant. Considered one of the best, if not the best of its class.

Parquette-An old standard white, variety; flower pure white, about an inch in diameter. Flowers in clusters from five to fifty blos. soms.

Perle D'Or-Nankeen yellow with orange center. Bush very branching, blooming in clusters of twenty to thirty flowers.

\section{TREE ROSES}

These are top-grafted or budded upon strong growing wild stocks at a distance of $3 \frac{1}{2}$ to $4 \frac{1}{2}$ feet from the ground. They thus form tree-shaped plants, nicely headed, and with proper care they are very desirable. We offer them in all colors.

Crimson Rambler Tree Rose The beauty and vigor of this remarkable rose is now well known from ocean to ocean, but grown as a tree, it is a novelty sure to be. come even more popular than in bush form. Its great vigor and hardiness make it especially adapted for this form of growth. 


\section{INSECT ENEMIES AND HOW TO DESTROY THEM}

We embody herewith brief but plain descriptions of the various insects which attack different classes of trees and plants, and in each case the best known remedy. Our directions can be relied upon implicitly, and we need only ask our friends and customers to follow the directions in cach case to the letter.

\section{DIRECTIONS FOR PREPARING THE REMIEDIES.}

Paris Green or London Purple-These poisons are used either in solution or dry form. In solution one pound is mixed with from 100 to 300 gallons of water, the streng:h depending on the plant sprayed and the insects to be destroyed. The poison should first be mixed with enough water to form a paste, after which the full quantity may be added. It is always best to add one or two pounds of lime for each pound of the green, as the danger to foliage will be much lessened thereby. Paris Green alone is sometimes applied in dry form. It is best, however, to mix each pound with ten pounds of flour or plaster. The liquid is much less objectionable, and we would in all cases recommend it.

Kerosene Emulsion-Take common bar soap, one-half a pound, water one gallon, and kero. sene two gallons. Shave the soap into the water, then beat the whole until all the soap is disselved; add the soap liquid, boiling hot, to the kerosene, and churn for ten minutes by pumping it back into itself; when cool, the emulsion sliould have the consistency of thick cream or soft butter, this depending somewhat upon the kind of soap used.

\section{INSECTS AFFECTING THE GRAPE-The Flee Beetle}

This small, steel blue insect, appears in early spring, and at once begins eating the tender foliage. After eating about a moment the female beetle deposits small vellow eggs on the foliage. 'These soon hatch into small larvae, which continue the work of destruction.

Remedies-Spray with Paris Green, one pound, and one and nne-half pounds lime to 200 gallons of water, as soon as the beetles are noticed. Two applications of this solution at intervals of a week or ten days, will usually destroy all the insects.

\section{The Rose Bug}

It makes its appearance early in the summer, devouring flowers, young fruit and leaves. The beetle is about half an inch long and of a brown color.

Remedies-The best results have followed the use of Pyrethrum, which should be applied in solution at the rate of one ounce to two gallons of water.

\section{INSECTS AFFECTING THE APPLE-The Coddling Moth}

The little white caterpillar, whose affects are so familiar to everyone, is the larvae of a small, nocturual, gray moth. The moth deposits her eggs on the blossom end of the fruit. As soon as the eggs hatch the larvae eats its way into the young fruit; the rest of the story is well known to everyone.

Remedie- - Spray the trees with Paris Green or Iondon Purple at the rate of one pound to 250 gallons of water, add one and a half pounds of lime, first when the flowers are falling and again when the fruit is the size of peas.

\section{The Canker Worm}

This measuring worm eats the green portion of the leaf, giving the tree a brownish color, as though scorched by fire. The worms appear in early spring, and when full grown are an inch long.

Remedies-Spray the trees when the leaves are one-third grown, with Paris Green s^lution, one pound to 200 gallons of water, add one and a half pounds of lime. Usually one spraying will be sufficient, but if the worms appear to be on the increase a second application will be advisable.

\section{Apple Tree Tent-Caterpillar}

The large silken nests made by this insect are familiar to everyone. The caterpillars appear in May or June, and in five or six weeks have attained their full size.

Remedies-Cut out and burn the nests as soon as they are seen, taking the precaution to do this in the morning when the caterpillars are all in. This, together with one or two sprayings of Paris Green solution, having a strength of one pound to 200 gallons of water, and one and a half pounds of lime, will effectually rid the trees of the pest.

\section{The Apple Aphis}

Apple trees are often attacked early in the season by this insect. The lice are quite small and green in color. By sucking the juices from the young growth they greatly interfere with the functions of the latter, and as a result the tree has a sickly, yellow appearance.

Remedies-Spray with kerosene emulsion at the rate of one gallon to twenty of water. as soon as the lice appear. Repeat the treatment in eight or ten days if necessary. A decoction made by soaking over night four or five pounds of tobacco stems, or refuse tobacco of any kind, in five gallons of water, will also be found an excellent remedy against the lice.

\section{The Oyster Shell Bark I.ouse}

There are frequently seen on the trunks, branches and twigs of the apple tree, small, whitish shells, resembling in shape those of an cyster. Under these shells are numerous small lice busily engaged in sucking the sap from the tree.

Remedies-Scrape the trees thoroughly in spring before the leares appear and then paint the trunk and large limbs with a thick solution made by dissolving one quart of soft soap in half a gallon of hot water. Two ounces of crude carbolic acid added to this will also increase its efficacr. Make no further treatment wntil the middle of May, when kerosene emulsion, one gallon to twenty-five gallons of water, shonld be applied. It is always best to apply the emulsion soon after the lice hatch. 


\section{INSECTS AFFECTING THE PEACH-The Black Aphis}

Numbers of this small, shiny black insect may be seen in the spring on the leaves and twigs of the peach. The lice often do a great deal of damage above ground as well as below on the roots.

Remedies-For the form above ground, spraying with kerosene emulsion, one gallon to thirty-five gallons of water, is the most effective reliedy. The first spraying should be made as soon as the lice appear; if necessary, this should be followed by others at intervals of a few days until the trees are rid of the pest. Under the ground the lice are best destroyed by digging in tobacco stems or dust among the trees. The tobacco is scattered on the ground to the deptn of hatf au inch or more, then dug in with a spade or fork.

\section{Peach Yellows}

This is one of the few diseases as to which very little is positively known, except its effects. It usually makes its appearance about mid-summer, causing the foliage of the tree to turn yellow, and soon thereafter the body and large limbs will throw out a considerable number of weak, yellow leaved suckers. If the tree is loaded with fruit it will be under size, little or no flavor, and ripen prematurely.

Remedies-The moment that $\mathrm{ycu}$ fcel sure that a tree is affected with yellows, dig it up root and branches and burn it, and planı any tree that you like, other than a peach tree, in its place.

\section{INSECTS AFPECTING THE PEAR-The Pear Tree \$lug}

This insect attacks the leares, eating away the green portion so that nothing remains but the parchment-like tissues and veins. It appears usually the latter part of June and again in August.

Remedies-Spraying with a simple solution of milk of lime, made by mixing two pounds of lime, in twenty gulluns of water, will often rid the tree of this pest. The first application sliould be made as socn as the slugs are noticed; if necessary, others should follow in a week or ten days. By adding a little Paris Green, say one ounce to the lime of milk, the latter will be made more effectual.

\section{The Scurfy Bark Louse}

This insect resembles the Oyster Shell Bark Louse already described as attacking the apple. Remedies-The same as for Oyster Shell Bark Louse.

\section{Pear Blight}

It is understood by the best authorities, both practical and scientific, that the cause of the disease is absolutely unknown, and there is but one certain remedy, namely to cut out the blighted parts promptly on appearance of the disease and burn them.

\section{INSECTS AFFECTING THE PLUM-The Curculio}

This little grub originates from eggs deposited by a small, dirty gray beetle, when the flowers are still small.

Remedies-The most reliable way now known of dealing with Curculio is to spray it with Paris Green. The first application should be made when the flowers are falling, using a solution made by mixing one pound of Paris Green in 200 gallons of water, and adding one and a half pounds of lime. In a week or ten days make a second application, and follow this by another after the lapse of same length of time.

\section{The Plum Tree Aphis}

This insect resembles the one occurring on the peach, and like it may be destroyed by spraying with kerosene emulsion, made by mixing one gallon of the concentrated emulsion in twenty gallons of water.

\section{Black Knot}

The most scientific as well as practical fruit growers in the country are by no means agreed as to the cause of Black Knot on plum and cherry trees, but they are entirely agreed as to the only known remedy, namely: Just as soon as the Black Knot appears cut it uut, removing the branch at least two inches below where the knot appears. Burn the affected parts and follow this method promptly, thoroughly, and in most cases, you will have exterminated the disease before it has done serious damage.

\section{INSECTS AFFECTING THE CHERRY}

The Cherry is injured by plant lice, resembling those occurring on the peach or plum. The Pear Tree Slug also attacks the leaves, while the fruit is infested by the Plum Curculio.

Remedies-The remedies given under peach and pear insects should be adopted in this case.

\section{Black Knot}

Cherry trees are affected with Black Knot the sime as the plum trees, and the same remedies should be used.

INSECTS AFFECTING THE CURRANT AND GOOSEBERRY-The Currant Worm

The perfect form of the worm is a small fly, which lays its eggs on the leaves in early spring. As soon as the eggs hatcli, the worms eat circular holes in the fuliage. As the worms increase in size, they become more voracious, often riddling the leaves.

Remedies-As soon as the worms are seen, spray the plants with a solution made by mixing one ounce of He? ebore in two gallons of water.

\section{The Currant Aphis}

The insect ittacks the leaves, causing them to curl and turn brown. The lice are usually abundant in early summer, but as hot weather advances tiley disaplear.

Remedies-Spray with kerosene emulsion, one gallon to twenty gallons of water, as soon as the lice are noticed.

\section{INSECTS AFFECTING THE ROSE}

The Rose Bug-The same as sometimes attacks the grape. Remedies-The same.

The Green, Aphis-The same that attacks the apples. Rcmedies-The same.

The Black Aphis-The same that attacks the peach and other trees. Remedies-The sanif 


\section{N D EX}

Page

6-12

Apples

Apricots

42

Asparagus

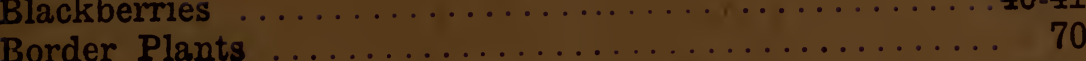

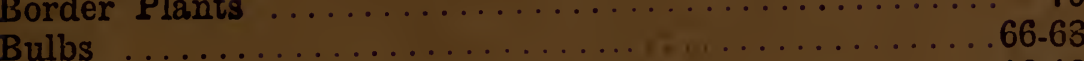

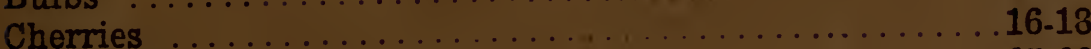

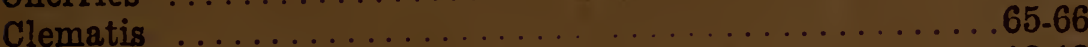

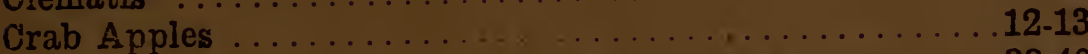

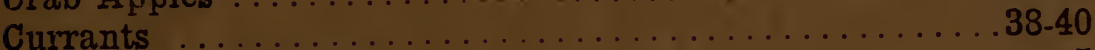

Distance for Planting ....................... 5

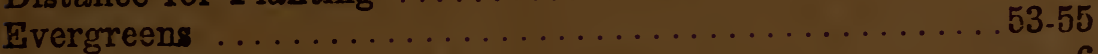

Fruit Department $\ldots \ldots \ldots \ldots \ldots \ldots \ldots \ldots \ldots \ldots \ldots$

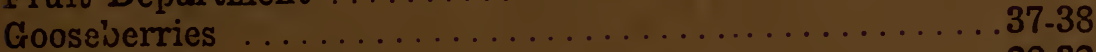

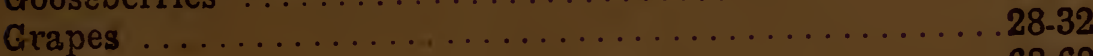

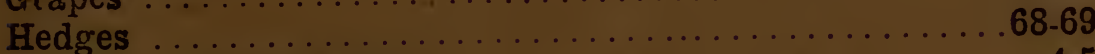

Hints on Transplanting $\ldots \ldots \ldots \ldots \ldots \ldots \ldots \ldots \ldots . \ldots \ldots$

Insect Fnemies $\quad \ldots \ldots \ldots \ldots \ldots \ldots \ldots \ldots \ldots \ldots$

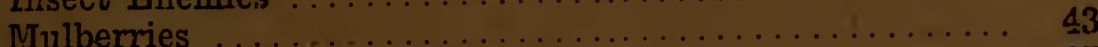

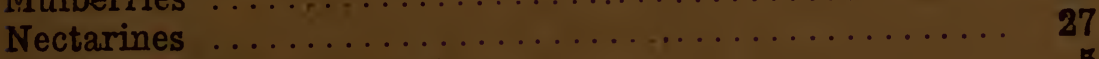

Number of Trees on an Acre ................. b

Puts ............................ 43

Oranges ................................ 43

Ornamental Department $\ldots \ldots \ldots \ldots 4$

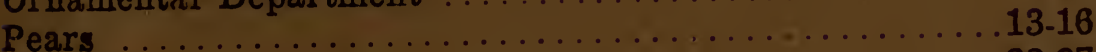

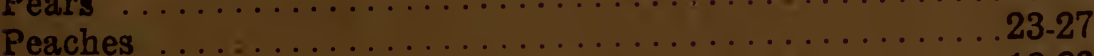

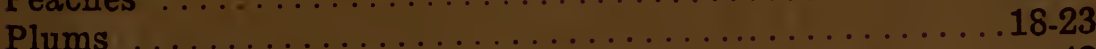

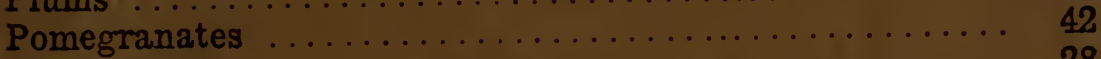

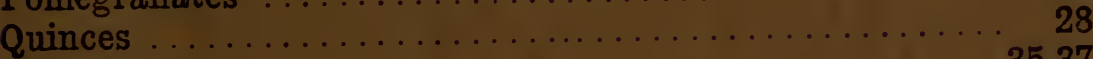

Raspberries ......................... 35-37

Rhubarb .

Roses . . . . . . . . . . 71-80

“ Hardy . . . . . . . . . . . . . . . . . . . . . 72-75

“Climbing

“Dwarf

“Moss .............................. 78

“Tender ............................ $78-80$

“ Polyantha ........................ 80

“ Rosa Rugosa ......................... 75

“Tree Form $\ldots \ldots \ldots . \ldots 80$

Scions and Stocks . . . . . . . . 43

Shrubs, Climbing $\quad \ldots \ldots \ldots \ldots . \ldots .6 .66$

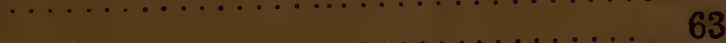

“ Upright . . . . . . . .55.63

Strawberries ..................................

Trees, Upright . . . . . . . . . . . . . . . . . . . 45-51

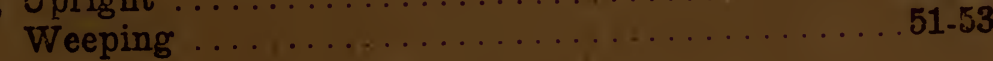




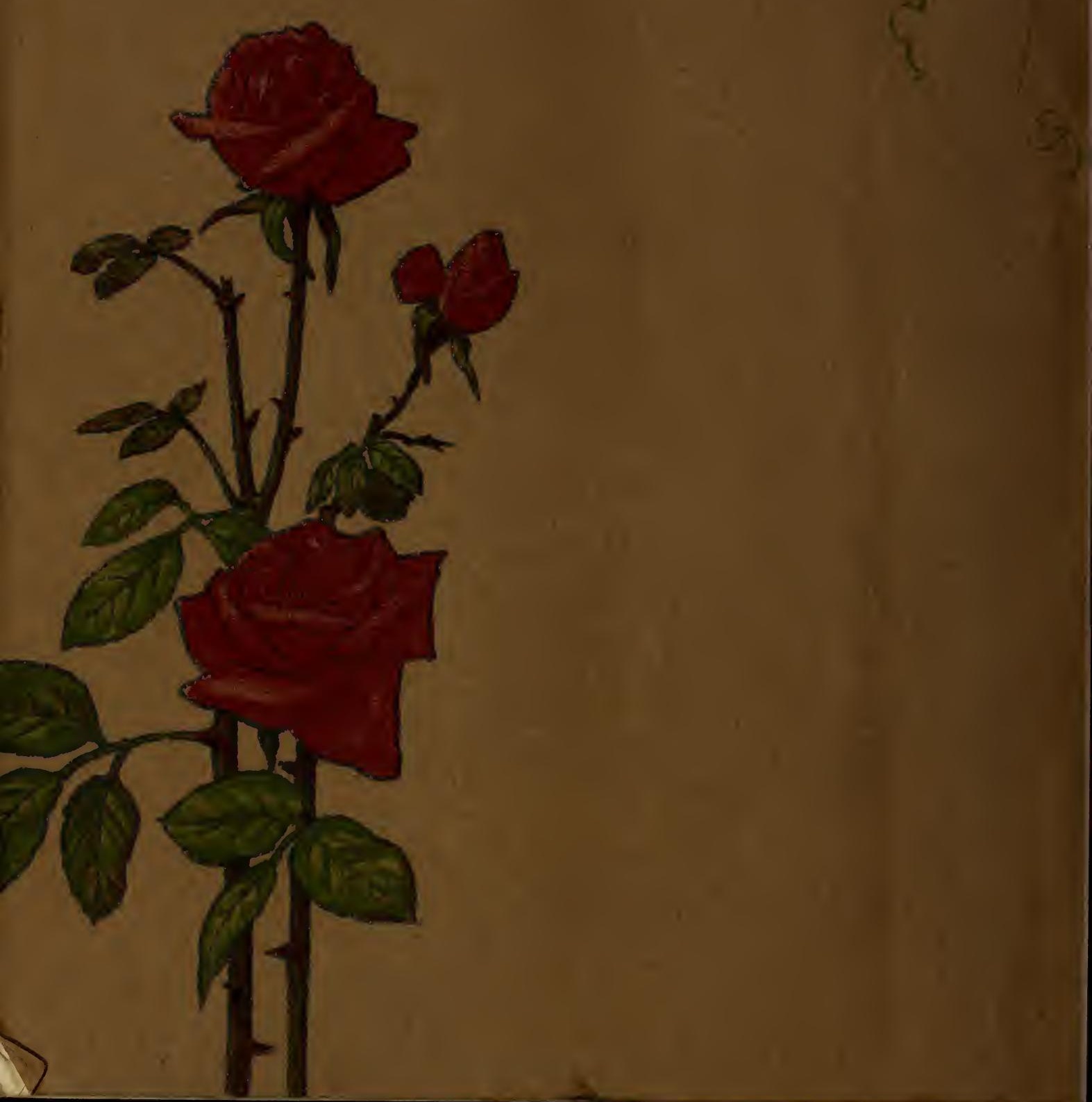

